\title{
Deep drilling of intact ocean crust: harnessing past lessons to inform future endeavors ${ }^{1}$
}

Expedition 335 Scientists $^{2}$

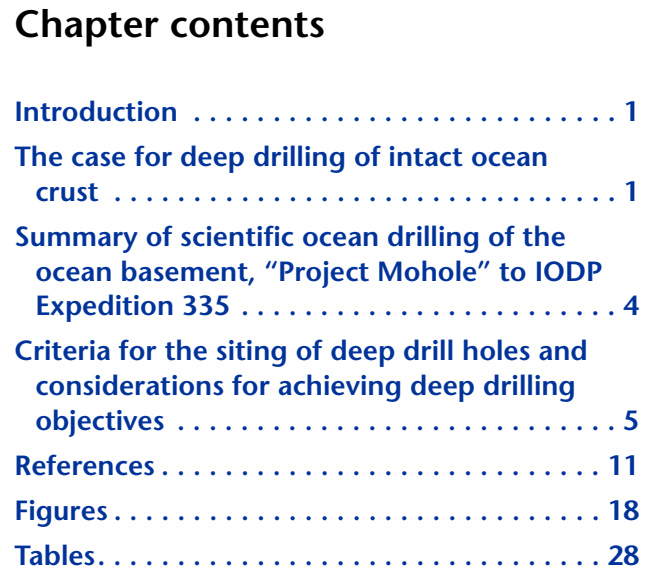

${ }^{1}$ Expedition 335 Scientists, 2012. Deep drilling of intact ocean crust: harnessing past lessons to inform future endeavors. In Teagle, D.A.H., Ildefonse, B., Blum, P., and the Expedition 335 Scientists, Proc. IODP, 335: Tokyo (Integrated Ocean Drilling Program Management International, Inc.). doi:10.2204/iodp.proc.335.104.2012

'Expedition 335 Scientists' addresses.

\section{Introduction}

This chapter provides a review of the scientific imperatives for deep drilling of oceanic crust, a review of past successes and challenges with deep drilling, thoughts on the siting of deep boreholes, and final comments on scientific ocean drilling programmatic changes that would enhance the success of deep drilling experiments in ocean lithosphere.

\section{The case for deep drilling of intact ocean crust}

Drilling a complete in situ section of ocean crust has been an unfulfilled ambition of Earth scientists for many decades and provided the impetus for the conception of scientific deep ocean drilling. The production of new crust at mid-ocean ridges lays the foundation of the plate tectonic cycle and is a dominant process that has resurfaced $>60 \%$ of our present-day planet since the Early Jurassic $(<200 \mathrm{Ma})$. Magma eruption and intrusion, along with ocean floor hydrothermal exchange, are the principal mechanisms of heat and material transfer from the mantle to the crust, oceans, and atmosphere. The ocean crust is an environment of steep thermal, physical, and chemical gradients potentially with many of the ingredients required to initiate primordial life, as there is growing evidence for an enduring, active subsurface basalt-hosted microbial biosphere (e.g., Fisk et al., 1998; Bach and Edwards, 2003; Santelli et al., 2008; Rouxel et al., 2008; McLoughlin et al., 2009; McCarthy et al., 2011). Evidence for microbial activity was also recently reported in $\sim 1$ m.y. old gabbros collected during Integrated Ocean Drilling Program (IODP) Expedition 304/ 305 (Mason et al., 2010). Chemical exchanges between the ocean and crust over a wide range of temperatures exert major controls on seawater chemistry and partially buffer inputs from the erosion and weathering of continents brought to the oceans by rivers, glaciers, and groundwater (e.g., Palmer and Edmond, 1989; Vance et al., 2009).

Unfortunately, many of the key questions regarding the formation and evolution of the oceanic crust that are primary scientific goals of the IODP Initial Science Plan and numerous forerunner questions remain unanswered despite 50 years of scientific ocean drilling. This is principally due to the cursory sampling of the ocean crust, and in particular an absence of continuous deep 
crustal sections (see Wilson, Teagle, Acton, et al., 2003; Teagle et al., 2004; Dick et al., 2006; Ildefonse et al., 2007c). These fundamental questions remain compelling and increasingly relevant to understanding the wider Earth system with the growing appreciation of the interdependency between geological, climatic, and biogeochemical cycles.

\section{Why study crust forming at fast spreading rates?}

The vast majority ( 70\%) of magma derived from the mantle is brought into the Earth's crust at the mid-ocean ridges, and approximately two-thirds of that magma cools and crystallizes in the lower portion of the oceanic crust. Seismic, bathymetric, and marine geological observations indicate that ocean crust formed at fast spreading rates (full rate $>80$ $\mathrm{mm} / \mathrm{y}$ ) is much less variable than crust formed at slow spreading rates $(<40 \mathrm{~mm} / \mathrm{y})$ and is closer to the ideal "Penrose" pseudostratigraphy developed from ophiolites (Anonymous, 1972). Hence, extrapolating fast-spreading accretion processes from a few sites might reasonably describe a significant portion of the Earth's surface. Although $<20 \%$ of modern ridges are moving apart at fast spreading rates (Fig. F1), nearly $50 \%$ of present-day ocean crust and $\sim 30 \%$ of the Earth's surface was produced at this pace of spreading (Fig. F2). The great majority of crust subducting into the mantle over the past 200 m.y. formed at fast-spreading ridges (Müller et al., 2008), making characterizing this style of crust most relevant for understanding the recycling of crustal and ocean-derived components back into the mantle.

The spreading rate of the oceanic lithosphere has profound effects on the style of crustal accretion at mid-ocean ridges because of changing balances between plate motion, magma production, conductive and hydrothermal cooling, detachment tectonics, and serpentinization of the upper mantle (e.g., Dick, 1989; Cannat et al., 1995, 2004, 2009; Chen and Phipps Morgan, 1996; Dick et al., 2003; Escartin et al., 2008). Although insights on the formation of intrusive crust at detachment-dominated, slow-spread lithosphere have been obtained (Ocean Drilling Program [ODP] Legs 118, 153, 176, and 209 and IODP Site U1309; e.g., Dick et al., 2000; Blackman, Ildefonse, John, Ohara, Miller, MacLeod, and the Expedition 304/305 Scientists, 2006; Kelemen, Kikawa, Miller, et al., 2004; Ildefonse et al., 2007a; Blackman et al., 2011), the thermal regime and the melt supply and delivery in these settings differs significantly from those of the axial zone in fast-spreading lithosphere. Detailed understanding of the relatively uniform mechanisms operating at fast-spreading ridges would provide a vital benchmark against which het- erogeneous accretion at slow-spreading ridges could be compared.

\section{The need for basic geologic observations of ocean crustal architecture}

Basic observations regarding the architecture of in situ present-day ocean crust, including rock types, geochemistry, and thicknesses of the volcanic, dike, and plutonic sections, are yet to be made. It is a fundamental weakness of our knowledge of the ocean crust that we are as yet unable to relate seismic and magnetic imaging of the ocean crust and geochemical inferences to basic geologic observations. We do not have a predictive understanding of the factors controlling the thicknesses of seismic and geological layers in the oceanic crust, which greatly precludes our ability to interpret regional geophysical data in geological terms. Drilling a few deep drill holes into intact ocean crust and studying samples having a range of seismic behaviors could greatly increase the confidence with which we interpret geophysical data and its use as a three-dimensional regional mapping tool (e.g., Fig. F3). Earth scientists often loosely speak of "Layer 3" when referring to the plutonic rocks of the ocean crust. However, the geological meaning and physical causes of the transition from seismic Layer 2 to Layer 3 velocities remain poorly understood. In Deep Sea Drilling Project (DSDP) Hole $504 \mathrm{~B}$, the only place where the Layer $2-3$ transition has been penetrated in situ, the Layer 2-3 transition occurs near the middle of the $\sim 1 \mathrm{~km}$ thick sheeted dike complex, where the transition to gabbroic rocks is at least $600 \mathrm{~m}$ deeper in the crust (Alt, Kinoshita, Stokking, et al., 1993; Detrick et al., 1994). At Site 504 the change from Layer 2 to Layer 3 appears to be related to changes in the secondary hydrothermal mineralogy (Alt et al., 1996) and/or crack porosity (Carlson, 2010). Whether this observation from the intermediate spreading rate crust sampled in Hole $504 \mathrm{~B}$ is applicable to other spreading rates or ocean crust in general is yet to be tested.

Marine magnetic anomalies are one of the key observations that led to the development of plate tectonic theory, through the recognition that the ocean crust records the changing polarity of the Earth's magnetic field through time (Vine and Matthews, 1963). Micrometer-sized grains of titanomagnetite within the erupted basalt are generally accepted to be the principal recorders of marine magnetic anomalies, but recent studies of tectonically exhumed lower crustal rocks and serpentinized upper mantle indicate that these deeper rocks may also be a significant source of the magnetic anomaly signal (Kikawa and Ozawa, 1992; Pariso and Johnson, 1993; Shipboard Scientific Party, 1999; Gee and Kent, 2007). Whether these 
deeper rocks have a significant influence on the magnetic field in undisrupted crust is unknown, as is the extent of secondary magnetite growth in gabbros and mantle assemblages away from transform faults. Sampling the plutonic layers of the crust could refine the Vine-Matthews hypothesis by characterizing the magnetic properties of gabbros and peridotites through drilling intact ocean crust, on a well-defined magnetic stripe, away from transform faults.

The most prominent melt feature observed by multichannel seismic experiments at fast-spreading midocean ridges is a low-velocity zone some tens of meters thick, hundreds of meters across axis, and commonly continuous for many hundreds of kilometers along axis (e.g., Kent et al., 1994). This low-velocity zone is interpreted to be a dominantly magma rich lens (e.g., Detrick et al., 1987; Vera et al., 1990; Hussenoeder et al., 1996; Singh et al., 1998) that overlies a lower crustal region of reduced $P$ - and $S$-wave velocities interpreted to be a hot crystal mush zone containing no more than a few percent of interstitial melt (e.g., Caress et al., 1992; Sinton and Detrick, 1992; Dunn et al., 2000). The roles of the low-velocity zone and axial magma lens in constructing fastspreading ocean crust remain controversial. A family of elegant thermally based numerical models attempts to build the lower crust from the continuous subsidence of cumulate layers formed at the base of the axial melt lens (Fig. F4) (Sleep, 1975; Henstock et al., 1993; Phipps-Morgan and Chen, 1993; Quick and Denlinger, 1993). These models have major implications for the composition and deformation of the lower crust, but many of these predictions are not borne out by observations in ophiolites or the limited fast-spread plutonic ocean crust drilled to date. For example, petrologic observations from Hess Deep suggest that the uppermost gabbros, interpreted to represent the axial melt lens that formed the crust, are late-stage melt fractions, even more differentiated than erupted mid-ocean-ridge basalt (MORB), and question the significance of the axial melt lens in the formation of the lower oceanic crust (e.g., Natland and Dick, 2009).

The itinerary of melt formed by the partial melting of the mantle to its eruption on the seafloor remains poorly understood. For more than two decades it has been assumed that the compositions of MORB erupted onto the ocean floor can be interpreted as a direct result of mantle melting (e.g., Klein and Langmuir, 1987; McKenzie and Bickle, 1988). The evolved chemistry of MORB and rarity of very primitive lavas indicate that nearly all lavas erupted at the ridge crests are processed in magma chambers. However, whether fractionation is solely responsible for magma chemistry remains unquantified. Recent results from fast- and slow-spreading ridges (e.g., $\mathrm{Ru}$ bin and Sinton, 2007; Lissenberg and Dick, 2008; Suhr et al., 2008; Godard et al., 2009; Drouin et al., $2009,2010)$ indicate that significant reactions can occur between melts and lower crustal cumulates or mantle rocks. The extent to which melt-rock interactions bias our current understanding of mantle melting processes cannot be assessed without studying the genetically conjugate cumulate rocks with their daughter extrusive lavas (and ultimately the source mantle rocks). Eventually, what will be required is a bulk chemical inventory of a complete section of ocean crust.

The manner of passage of melt through the lower crust to the axial melt lens or to feed the dike and volcanic layers also remains poorly understood. Gabbros that crop out in ophiolites commonly exhibit fine-scale modal and geochemical layering, but these textures are difficult to reconcile with models of grain boundary flow of upwelling magma through a lower crust that mostly comprises a crystal mush (e.g., Korenaga and Kelemen, 1997). Discrete channels that feed magma into the axial melt lens or higher levels are yet to be identified in intact ocean crust (cf. MacLeod and Yaouancq, 2000).

The latent and specific heat from cooling and crystallizing magma is the principal driving force for hydrothermal circulation, with the energy available a function of the volume, distribution, and timing of magma intrusions. Within a few hundred meters of the ridge axis, the ocean crust appears completely solid to seismic waves and a clear Moho is generally observed. This requires that, at the very least, the latent heat of crystallization and sensible heat for cooling the magma to the solidus for the $\sim 6 \mathrm{~km}$ of new crust at the ridge must have been exported from the system. The timescales are too short $(<25,000 \mathrm{y})$ for this heat export to be achieved solely by conduction, requiring advection of heat by hydrothermal circulation. How this can be achieved in the upper crust is easy to envisage, but the importance and geometry of latent and sensible heat extraction from the deep crust by hydrothermal fluids remain poorly known and provide a key difference in competing models of magmatic accretion at fast-spreading ridges (Fig. F4) (Sleep, 1975; Henstock et al., 1993; Dunn et al., 2000; Garrido et al., 2001; Maclennan et al., 2005).

The compositions of fluids venting into the ocean at high-temperature black smokers and other types of vents are controlled by the physiochemical conditions and the extents of fluid-rock reactions within the crust (e.g., Mottl, 1983; Seyfried et al., 1999; Jupp and Schultz, 2000; Coumou et al., 2008). The rate of 
cooling of magma is in turn controlled by the extent of fracturing and resulting permeability, the consequent geometry and vigor of high- and low-temperature hydrothermal circulation, and the rates of fluidrock exchanges. Some numerical models and ophiolite data (e.g., Maclennan et al., 2005; Bosch et al., 2004; Gregory and Taylor, 1981) require that seawater circulation extends to depths of several kilometers close to the ridge axis to mine the latent heat from deep in the crust and hence directly controls accretionary processes in the lower crust. Unfortunately, deep circulating fluid fluxes are poorly determined, and the conclusive geochemical tests of this scenario in an intact section of ocean crust remain to be conducted (e.g., Coogan et al., 2002, 2005; Van Tongeren et al., 2008). Sparse analyses of hydrothermal veins from gabbros indicate insufficient fluid volumes to significantly cool the lower crust (Coogan et al., 2007). The chemistry of black-smoker fluids suggests rock-dominated fluid exchange with the crust and regional recharge, but faults may play a role in facilitating the penetration of seawater-derived fluids to enable the cooling of the deep crust (e.g., Coogan et al., 2006). However, to date there is little evidence from intact ocean crust on whether faults, or other channels for seawater penetration down into the lower crust, are important for cooling the lower crust and for the advection of ocean-derived geochemical tracers or microbial populations to depth (e.g., Mason et al., 2010). Microbial populations seek out high thermal/chemical gradients; hence, the variation in the location/properties of faults and other zones of enhanced crustal fluid recharge are expected to determine the diversity of the ecosystem at depth within the crust.

An important recent advance comes from the recognition that the sheeted dike complexes of all intermediate to fast-spread systems studied (DSDP Hole 504B and ODP Hole 1256D and seafloor samples from Hess Deep and Pito Deep tectonic windows) provide relatively consistent estimates of axial hightemperature fluid fluxes (e.g., Teagle et al., 1998a, 2003; Gillis et al., 2005; Barker et al., 2008; Harris et al., 2008; Harris, 2011; Coggon, 2006; Nielsen et al., 2006; Chan et al., 2002). These estimates are all much lower than hydrothermal fluxes estimated from global seawater budgets, hydrothermal vent observations (e.g., Elderfield and Schultz, 1996), or studies of ophiolites (Bickle and Teagle, 1992), but their consistency with thermal calculations gives confidence in their validity. This sets the stage for estimates of chemical fluxes between this zone and the oceans and the impact of axial hydrothermal alteration on global chemical cycles (e.g., Davis et al., 2004; Vance et al., 2009).

\section{Deep scientific ocean drilling is the only approach that can provide basic geologic observations on the formation and evolution of fast-spreading ocean crust}

To date there remains a near-complete lack of direct observations regarding the accretion occurring beneath the dike layer at fast-spreading ridges. Importantly, we have well-developed but competing theoretical and geological models of the styles of magmatic accretion at fast-spreading ridges (Fig. F4). These models have been developed from a wide evidence base from marine geology and geophysics, as well as studies of ophiolites. Unfortunately, none of the best preserved ophiolites likely formed in major ocean basins (e.g., Miyashiro, 1973; Rautenschlein et al., 1985; Miyashita et al., 2003; Stern, 2004). Although ophiolite outcrops will continue to provide invaluable inspiration for ocean crustal studies, their direct relevance to intact ocean crust remains unproven. Although tests have been developed, the appropriate materials and observations to challenge these hypotheses remain elusive because the key processes of crustal accretion occur through magma intrusion deep within the crust. These critical samples and data can only be recovered by deep scientific drilling of intact ocean crust.

\section{Summary of scientific ocean drilling of the ocean basement, "Project Mohole" to IODP Expedition 335}

In March-April 1961, the drilling barge CUSS1 undertook the first scientific ocean drilling operation off Guadalupe Island, $240 \mathrm{~km}$ west of Baja California (Mexico). This expedition, beautifully reported in LIFE magazine by the novelist John Steinbeck and the renowned science photographer Fritz Goro, was the first (and eventually only) concrete manifestation of Project Mohole. This project was a very ambitious endeavor proposed in the late 1950s by the American Miscellaneous Society (AMSOC), an informal group of notable US scientists, mostly geophysicists and oceanographers associated with the Office of Naval Research, including Harry Hess and Walter Munk. The principal aim was to drill through the oceanic crust, through the Mohorovicic discontinuity, and to retrieve samples from Earth's mantle. In his book A Hole in the Bottom of the Sea, Willard Bascom, Director of Project Mohole, records that the AMSOC elaborated on and initiated the project over a wine breakfast at Munk's La Jolla home in April 
1957, following on from original ideas discussed by Walter Munk and Harry Hess (Bascom, 1961). Bascom also notes that probably the first written suggestion for a deep penetration down into the mantle was given by Frank Estabrook, an astrophysicist from the Basic Research branch of the US Army in Pasadena (California, USA) in a letter "Geophysical Research Shaft" published in Science in 1956 (Estabrook, 1956).

IODP Expedition 335, the fourth expedition of the "Superfast" campaign to core an intact section of ultrafast-spread oceanic crust, coincided with the fiftieth anniversary of the drilling expedition in 1961 (Teagle and Ildefonse, 2011). The US National Academy of Science has launched a web page to commemorate the innovative accomplishments of Project Mohole (www.nationalacademies.org/mohole.html). These accomplishments include the invention of dynamic positioning, the drilling guide horn, and deepwater drill hole reentry-all conceived and accomplished years before the offshore petroleum industry ventured into the open ocean. The drilling expedition in 1961 cored for the first time seismic Layer 2 and demonstrated with core that the uppermost ocean crust was made up of basaltic lavas. This achievement received a personal letter of congratulations from President Kennedy. Unfortunately, following divorce from the original scientific architects and vast cost overruns, Project Mohole progressively lost momentum with no further drilling accomplished, resulting in the ignominious termination of the project by the US Congress in 1965 (Shor, 1985; Greenberg, 1974). Despite often being recounted as a major geopolitical fiasco, this project has had an enduring impact on the Earth sciences by demonstrating that drilling in the deep ocean was technically feasible. This coincided with the formulation and growing acceptance of plate tectonic theory and recognition of the high-resolution geological records and key roles played by the oceanic crust and overlying sediments in major Earth cycles. Project Mohole's direct offspring was the pioneering Deep Sea Drilling Project (DSDP) that initiated more than 40 years of international collaboration for scientific ocean drilling.

Since the start of DSDP in 1968, oceanic basement has been drilled in a range of geodynamic settings, and a compilation of holes into the ocean crust cored by scientific ocean drilling since the beginning of DSDP is presented in Table T1 and Figures F5 and F6. This compilation does not include other "hard rock" drill holes in oceanic plateaus, arc basement, hydrothermal mounds, or passive margins. Only 34 holes deeper than $100 \mathrm{~m}$ have been cored in oceanic crust since DSDP Leg 37 in 1974 (see Fig. F6). The recovered material represents $<2 \%$ of the $\sim 330 \mathrm{~km}$ of cores recovered to date by DSDP, ODP, and IODP. In spite of this relatively cursory sampling, scientific drilling has contributed significantly to advance knowledge of ocean crust architecture and mid-ocean-ridge accretion and hydrothermal processes (e.g., Alt et al., 1996; Teagle et al., 1998b; Dick et al., 2000, 2006; Ildefonse et al., 2007a, 2007c; Wilson et al., 2006; Blackman et al., 2011). Hole 504B, located on 6.9 Ma crust formed at an intermediate rate at the Costa Rica Rift (Fig. F5), remains the deepest hole (2111 mbsf) in all of scientific ocean drilling (Alt et al., 1996). This site was host to drilling and other experiments over eight DSDP and ODP legs and was the first hole to penetrate completely through the volcanic lava sequences and $\sim 1 \mathrm{~km}$ into sheeted dikes. It remains a reference hole for hydrothermal alteration of the ocean crust (e.g., Alt et al., 1986a, 1986b) and the geological structure of seismic Layers 2A, 2B, and 2C (e.g., Carlson, 2011). Hole 504B is the only location where the seismic Layer 2/3 boundary has been sampled in situ (Detrick et al., 1994; Carlson, 2010). However, a complete, continuous section of intact, homogeneous fast-spread crust down to the cumulate gabbro layers has yet to be drilled and remains a first-order scientific target for ocean drilling for the ocean crust research community (e.g., Dick and Mével, 1996; Murray et al., 2002; Teagle et al., 2004, 2009; Ildefonse et al., 2007b, 2010a, 2010b; Ravelo et al., 2010; IODP Science Plan 2013-2023 [campanian.iodp.org/NSP/iodp_sci_plan_broch.pdf]). Recently, IODP Expedition 312 penetrated to the base of the sheeted dike complex and the uppermost gabbro in Hole 1256D, which was the first sampling of the transition to plutonic rocks in intact ocean crust (Teagle, Alt, Umino, Miyashita, Banerjee, Wilson, and the 309/312 Scientists, 2006; Wilson et al., 2006). Further deepening of Hole 1256D into cumulate gabbros was the primary sampling objective of Expedition 335.

\section{Criteria for the siting of deep drill holes and considerations for achieving deep drilling objectives}

Deep drilling into intact and rifted ocean crust has posed, and will continue to present, major technical and programmatic challenges to scientific ocean drilling. Only four holes, DSDP Hole 504B, ODP Holes 735B and 1256D, and IODP Hole U1309D (Figs. F5, F6; Table T1), have been cored deeper than $1 \mathrm{~km}$ into oceanic basement, and these penetrations are arguably the greatest technical achievements of 
scientific ocean drilling. All were "hard won" multiexpedition experiments. From the experiences of drilling these holes, there are important lessons to be learned for the siting, planning, and implementation of future deep drilling of the oceanic basement (Table T2). Other deep objectives may be targeted by future scientific ocean drilling (e.g., subvolcanic zones of large igneous provinces and arcs), for which these observations are also relevant. Here, we present a short review of deep drilling operations in the four $>1 \mathrm{~km}$ basement holes penetrated by scientific ocean drilling, listed above. Although Holes 504B and 1256D drilled into intact ocean crust have been fraught with more drilling challenges than holes spudded directly into gabbro in oceanic core complexes (Holes 735B and U1309D), even those holes have proved troublesome to initiate (Hole U1309D) or maintain (Hole 735B).

\section{Drilling deep holes in crustal hard rocks: tales of patience and perseverance}

Difficulties encountered during Expedition 335 well illustrate the challenges faced by deep drilling of oceanic crust, especially while scientific ocean drilling operates in an expedition mode. On site at Hole $1256 \mathrm{D}, 93 \%$ of our time was spent on hole remediation and stabilization operations, with only 3-4 days spent coring $(\sim 4 \%)$. The interval cored eventually represents only $\sim 4 \%$ of our initial depth objective for the time scheduled for Expedition 335. Several problems were encountered for the very first time in the history of scientific ocean drilling, and many lessons were learned or relearned (see detailed descriptions in "Operations" in the "Expedition 335 summary" chapter [Expedition 335 Scientists, 2012]). The main lesson is that patience and perseverance are required, and given that problems are always encountered, in some cases major problems, when drilling deep holes in intact crust, this must be taken into account at the program scheduling stage to achieve success in drilling deep in the ocean crust.

Here we summarize the operational challenges encountered during this expedition, together with past hard rock drilling experience and difficulties, in particular when drilling deep in intact oceanic crust. This section addresses one of the recommendations made at the MoHole workshop in Kanazawa, Japan, in June 2010 (Ildefonse et al., 2010a), which is to assess the past experience in scientific ocean crustal drilling for optimizing the engineering development and drilling operations for a future MoHole project. Although the various events that led to tool or pipe failure and equipment loss in various drill holes have been reported in past leg and expedition reports and partially assessed by ODP and IODP, there is no directly available self-consistent documentation of drilling challenges in deep ocean crustal boreholes. This section compiles the history of problematic and sometimes traumatic events in the four deepest holes drilled to date in the ocean crust.

Among the four boreholes deeper than $1000 \mathrm{~m}$ in basement (Table T1; Figs. F5, F6), two of them, Holes 504B and 1256D, were drilled in the Pacific Ocean crust and penetrated through the upper crustal lavas and into the underlying sheeted dike complex.

\section{DSDP/ODP Hole 504B}

Hole 504B is located in the eastern equatorial Pacific $\left(1^{\circ} 13.611^{\prime} \mathrm{N}\right.$; $83^{\circ} 43.818^{\prime} \mathrm{W}$; Fig. F7) and is the deepest hole (2111 mbsf) ever drilled by scientific ocean drilling programs since the launch of DSDP in 1968 (e.g., Becker et al., 1989; Alt et al., 1996). Operations in Hole 504B were carried out over eight legs (DSDP Legs 69, 70, 83, and 92 and ODP Legs 111, 137, 140, and 148) between 1979 and 1993 (only seven of these eight legs were coring legs; Leg 92 returned to Hole 504B for downhole logging operations). The detail of operations can be consulted in the Site 504 chapters of these eight leg reports (Cann, Langseth, Honnorez, Von Herzen, White, et al., 1983; Honnorez, Von Herzen, et al., 1983; Anderson, Honnorez, Becker, et al., 1985; Leinen, Rea, et al., 1986; Becker, Sakai, et al., 1988; Becker, Foss, et al., 1992; Dick, Erzinger, Stokking, et al., 1992; Alt, Kinoshita, Stokking, et al., 1993). The full suite of operations in Hole 504B is summarized in Table T3, and major perturbing events are reported in Figure F8. All together, the time spent in experiencing various hardware failures and subsequent remediation represents $\sim 28 \%$ of the total time spent drilling, coring, logging, and sampling in Hole 504B ( 205 days). During Leg 148, the coring bottom-hole assembly (BHA) became so thoroughly stuck at the bottom of the hole that it was necessary to sever the pipe. Subsequent operations recovered part of this material and milled much of the remainder, but the hole was abandoned with the coring bit, the float valve, and the lower support bearing remaining at the bottom (Alt, Kinoshita, Stokking, et al., 1993). It should be noted that because Leg 148 directly followed ODP Leg 147 to Hess Deep (Gillis, Mével, Allan, et al., 1993), during which significant equipment was consumed because of coring and fishing operations, Leg 148 sailed without the full complement of fishing and milling equipment, and new equipment, materials, and personnel needed to be sent from shore to try to resurrect the hole (e.g., a fishing expert and drilling jars/intensifiers). The scheduling of back-to-back, in- 
dependent hard rock expeditions can put major stress on implementation organization resources.

\section{ODP/IODP Hole 1256D}

Hole 1256D is located in the Guatemala Basin on the Cocos plate, eastern Pacific $\left(6^{\circ} 44.16^{\prime} \mathrm{N} ; 91^{\circ} 56.06^{\prime} \mathrm{W}\right.$; Fig. F7), and is the only hole to date that reached the transition zone between the sheeted dike complex and the lower crustal gabbros in fast-spreading, intact ocean crust (Wilson et al., 2006). The first contact between dike and gabbros was recovered at 1406.5 mbsf on 13 December 2005 at $1400 \mathrm{~h}$ UTC. The detail of operations in Hole 1256D can be consulted in the Site 1256 chapters of the ODP Leg 206 Initial Reports volume (Wilson, Teagle, Acton, et al., 2003) and the Expedition 309/312 Proceedings volume (Teagle, Alt, Umino, Miyashita, Banerjee, Wilson, and the Expedition 309/312 Scientists, 2006). The full suite of operations in Hole 1256D is summarized in Table T4, and major perturbing events are reported in Figure F9. Most of our operation time during Expedition 335 (see "Operations" in the "Expedition 335 summary" chapter [Expedition 335 Scientists, 2012] for a detailed narrative) was used for (1) reopening the hole to the bottom and (2) cleaning the bottom of the hole after losing most of the first coring bit used. The three previous scientific ocean drilling expeditions required to build the upper crustal infrastructure for deep drilling and then advancing Hole 1256D to $>1500$ mbsf represent a significant investment for the ocean drilling community. Consequently, determined efforts have been made to resuscitate Hole $1256 \mathrm{D}$ and prepare and preserve it for future deepening during Expedition 335. The first problem was encountered in the 920-950 mbsf interval, where an obstruction encountered on the initial reentry prevented penetration to the bottom of the hole. Coring started 15.3 days after our first reentry in Hole 1256D. Our second major problem occurred shortly after that, when our first coring C9 bit disintegrated after cutting two cores. A long period of reaming and fishing continued until the end of the expedition, which concluded with logging operations, the retrieval of a final core (3351256D-239R), and cementing activities to stabilize the hole for a future return to Hole 1256D.

\section{Gabbro drilling at oceanic core complexes at slow-spreading ridges: Holes 735B and U1309D}

The two other deep holes (Hole 735B at the Southwest Indian Ridge and Hole U1309D at the Mid-Atlantic Ridge) were drilled in gabbroic plutons in the footwall of oceanic core complexes in slow-spread crust. They were initiated in bare rock (with only a few meters of soft sediment for Hole U1309D). The uppermost $20 \mathrm{~m}$ of Hole U1309D was cased using a hammer-in-casing technique to provide a safe and viable reentry system for a deep hole. Hole U1309D was drilled over two back-to-back expeditions in 2005 (Blackman, Ildefonse, John, Ohara, Miller, MacLeod, and the Expedition 304/305 Scientists, 2006), whereas Hole 735B was drilled during two ODP legs 10 years apart (in 1987 and 1997; Robinson, Von Herzen, et al., 1989; Dick, Natland, Miller, et al., 1999). Both holes were drilled to their terminal depth (1508 and 1415.5 mbsf for Holes 735B and U1309D, respectively) without major trouble related to drilling or coring. Gabbro has been the easiest lithology to drill and core in oceanic crust so far.

In Hole U1309D the only major difficulty encountered was related to the installation of the casing using the hammer-in-casing technique (see Blackman, Ildefonse, John, Ohara, Miller, MacLeod, and the Expedition 304/305 Scientists, 2006, for further details regarding the casing operations). The casing operation succeeded in Hole U1309D after a failed first attempt (IODP Hole U1309C). However, the casing could not penetrate deeper than 20.5 mbsf, leaving $4.5 \mathrm{~m}$ standing above the seafloor. The reentry cone was deployed at that point, and coring operations proceeded without noticeable incident until the end of Expedition 305, with an average total recovery of $\sim 75 \%$. Hole U1309D remains open for potential reentry and future deepening. The minimum temperature at the bottom of the hole is $110^{\circ} \mathrm{C}$ (Blackman, Ildefonse, John, Ohara, Miller, MacLeod, and the Expedition 304/305 Scientists, 2006).

Hole $735 \mathrm{~B}$ was similarly easy to drill, and the recovery at $\sim 86 \%$ is the highest achieved in oceanic hard rocks to date. It is the second deepest hole in oceanic basement after Hole 504B (1836.5 m) and the deepest penetration into slow-spread crust. The only major incident that unfortunately resulted in losing the hole occurred 12 days before the end of Leg 176, a few hours after coring had resumed following $\sim 1$ day of interrupted operations due to bad weather conditions (see Dick, Natland, Miller, et al., 1999, for a detailed narrative of the incident). The drill string failed following contact with a ledge in the hole when the vessel heaved down during a pipe connection make-up, and the BHA and $1403 \mathrm{~m}$ of drill pipe were lost in the hole. The first fishing attempt retrieved $497 \mathrm{~m}$ of drill pipe; the hole was abandoned at the end of Leg 176 after a total of eight unsuccessful fishing attempts, alternated with several milling runs. A combination of bad weather and bad luck was, in this case, the cause of failure. 


\section{Hess Deep, ODP Leg 147: a tectonic window into fast-spread lower oceanic crust}

Another historical record of hard rock drilling challenges and incidents is Leg 147 to Hess Deep in the eastern Pacific (Fig. F7) (Gillis, Mével, Allan, et al., 1993). The westward propagation of the tip of the Cocos-Nazca plate boundary into crust formed $\sim 1$ m.y. ago on the eastern side of the East Pacific Rise has resulted in the exposure of lower ocean crust and serpentinized upper mantle (e.g, Francheteau et al., 1992; Karson et al., 1992; Karson, 2002). This tectonic window provides an alternative approach to drilling through intact ocean crust (e.g., Holes 504B and 1256D), but to date drilling into Hess Deep gabbros and serpentinized peridotites has been very difficult to achieve, partly because of the very rugged topography and complex tectonic settings, resulting in boreholes probably intersecting numerous fault zones. A series of problems was encountered at the two sites, including difficulties to set up a threelegged hard rock base (HRB) designed for handling slopes as steep as $35^{\circ}$, hole deviation, and lost BHAs (see Gillis, Mével, Allan, et al., 1993, for a complete narrative of these events).

\section{Drilling young unsedimented lavas}

Drilling young basalt has also proved very difficult, especially when holes are spudded directly into bare rocks. All basaltic holes reported in Table T1 and Figure F6 were drilled in areas with a significant sediment cover that assists in the initiation, stabilization, and progress of the boreholes. Drilling in zeroage basaltic crust during DSDP (Leg 54) and ODP (Leg 142) at the East Pacific Rise was unsuccessful (Rosendahl, Hekinian, et al., 1980; Storms, Batiza, et al., 1993). More recent attempts have also had relatively limited success, recovering at best a few tens of centimeters before the holes had to be abandoned, such as at several sites attempted during Leg 209 at the Mid-Atlantic Ridge in the $15^{\circ} 20^{\prime}$ Fracture Zone area (Kelemen, Kikawa, Miller, et al., 2004). Initiating and progressing a hole deeper than $\sim 20 \mathrm{~m}$ (with very poor recovery) in the young basaltic hanging wall of the Atlantis Massif Core Complex also failed in spite of 11.5 days of continuous efforts, despite using the hard rock reentry system and rotary core barrel (RCB) coring successfully deployed to drill into gabbros during the same expedition (Expedition 304/305; Blackman, Ildefonse, John, Ohara, Miller, MacLeod, and the Expedition 304/305 Scientists, 2006).

\section{Considerations for the location of scientific wells with deep objectives}

\section{Location}

Although the overriding justification for the siting of drill holes must be scientific grounds, there is no doubt that geographic location plays a major role in the successful scheduling of operations at sites that require multiple visits to accomplish objectives. The proximity of a site only a few days steaming from a major port where resupply can occur greatly reduces expensive and fuel-consuming transit days and provides maximum operational days on site. This siting also reduces transport distances for equipment dispatch should unanticipated drilling situations occur (e.g., the dispatch of drilling jars/intensifiers and a specialist engineer to Hole 504B during Leg 148; Alt, Kinoshita, Stokking, et al., 1993) (Table T3). Proximity to shipping routes frequently transited by the drillship (e.g., the Panama Canal) facilitates repeated scheduling at higher frequencies than more remote locations. A benign 12 month weather window allows maximum flexibility for the scheduling of return visits and the efficient arrangement of expeditions to locations with more restricted weather conditions.

\section{Sediment cover}

Presently there is no effective technology to routinely initiate deep (or even shallow) holes in volcanic rocks directly exposed at the seafloor (e.g., Legs 54 and 142 and Expedition 304; see "Drilling young unsedimented lavas"). Even a small amount of sediment greatly stabilizes the drill bit and assists in the initiation of drilling (e.g., ODP Leg 187 and IODP Expedition 329). Deep drilling of volcanic and deeper rocks of the oceanic basement requires the installation of a reentry cone and subsurface casing, but presently this infrastructure can only be set successfully in volcanic rocks where there is thick sedimentary cover. The installation of a reentry cone has not been successfully attempted in a bare rock environment, with the exception of Hole U1309D in gabbroic basement (see "Gabbro drilling at oceanic core complexes at slow-spreading ridges: Holes 735B and U1309D"). This lack of success has led to a bias toward operations in regions of anomalously thick sediment cover, such as crust formed in the equatorial high-productively zone $\left( \pm 1^{\circ}\right.$ of the Equator; e.g., DSDP Holes 504B and 896A and ODP Hole $1256 \mathrm{D})$, on ocean crust very close to the continental margin (e.g., Juan de Fuca Ridge, ODP Leg 168 and 
IODP Expeditions 301 and 327), or in very old crust (e.g., DSDP Holes 417D and 418A and ODP Hole 801C; Donelly, Francheteau, Bryan, Robinson, Flower, Salisbury, et al., 1980; Lancelot, Larson, et al., 1990; Plank, Ludden, Escutia, et al., 2000). The deepest hole spudded into bare volcanic rock is only $50 \mathrm{~m}$ deep, and drilling was fraught with equipment failure and poor hole conditions (ODP Hole 648B, MidAtlantic Ridge; Detrick, Honnorez, Bryan, Juteau, et al., 1988). Generally at least $100 \mathrm{~m}$ of sedimentary overburden is required to mount a reentry cone supported by 20 inch casing, the minimum upper hole infrastructure recommended for deep drilling (e.g., Hole 1256D).

\section{Seismic velocities and alteration}

Young lavas are highly fractured, and it has proven difficult to initiate, maintain, and progress drill holes in young volcanic rocks. At the ridge axis, lava commonly flows beneath a thin, brittle carapace of quenched magma. These fragile surfaces collapse beneath subsequent lava flows, resulting in layers of poorly consolidated volcanic materials (e.g., Gregg and Fink, 1995; Gregg and Chadwick, 1996; Umino et al., 2000). Even more massive flows tend to have rubbly flow tops composed of glassy material that makes up substantial portions of the flows. Low-temperature hydrothermal alteration that occurs on the ridge flanks for millions of years leads to the precipitation of clays, principally $\mathrm{Mg}$ saponite, and other secondary minerals (e.g., celadonite, minor iron oxyhydroxides, calcium carbonate, and zeolites; Alt et al., 1986a) that replace mesostasis, fill fractures, and form breccia cements. Secondary mineral precipitation provides greater cohesion within the lava pile. This cohesion is reflected at a regional scale by increased seismic $P$-wave velocities (e.g., Carlson, 1998; Christeson et al., 2007) compared to younger crust closer to the spreading axis. However, these secondary minerals provide only weak bonding to fractured rocks. At any particular crustal age or region, relatively high seismic velocities probably reflect thicker or a greater abundance of massive lava flows relative to sheet flows, pillow lavas, or hyaloclastites. These latter lava morphologies are likely to be more highly fractured and include greater proportions of voids that present drilling hazards. Targeting areas with relatively higher seismic velocities will increase the probability of encountering stable formations in the uppermost basement, greatly increasing the chances of initiating a stable deep borehole, as demonstrated by the siting of Hole 1256D. However, drilling only more massive lavas may lead to a bias against more permeable and more altered oceanic crust, underestimation of hydrothermal exchanges between the oce- anic crust and seawater, and overestimation of in situ physical properties (e.g., discrete sample $P$-wave velocities).

\section{Age-depth-temperature}

For crust in all oceans, ocean depth and conductive heat flow are inversely proportional to the square root of the age of the ocean crust (e.g., Lister, 1972). Although older ocean crust is cooler at depth and lower basement temperatures should improve drilling and wireline tool performance, targets will be significantly deeper, increasing pipe trip and wireline times. Water depth and the total target depth are important considerations for the siting of a future riser drilling approach to core beyond the Moho and to a significant distance (hundreds of meters) into the upper mantle (e.g., Ildefonse et al., 2007b, 2010a, 2010b). Plans are being formulated for the development of an ultra-deepwater riser capability for the D/V Chikyu, but these enhanced capabilities are unlikely to be developed beyond $\sim 4000 \mathrm{~m}$ water depth. There is a discernible conductive heat flow anomaly out to $\sim 65$ m.y., indicating that the transport of heat by low-temperature hydrothermal circulation of seawater-derived fluids becomes on average negligible beyond this age (e.g., Stein and Stein, 1994). However, in individual regions, hydrothermal flow occurs wherever hydrological gradients can be established because of basement topography, variable sediment cover, or seamounts that penetrate the sediment overburden and provide pathways for the ingress of seawater and egress of basement fluids (e.g., Wheat and Fisher, 2008; Von Herzen, 2004). Whether this fluid flow is always accompanied by significant chemical reaction or microbial stimulus is as yet unconstrained. Dating of secondary minerals formed by low-temperature hydrothermal alteration remains challenging (e.g., Waggoner, 1993), but assessment of basement calcium carbonate veins, generally one of the latest phases to form, suggests that effective chemical exchange is complete within a few tens of millions of years of crustal formation (e.g., Coggon et al., 2010). There have been major changes in ocean chemistry since the Cretaceous and through the Tertiary (e.g., Stanley and Hardie, 1998; Lowenstein et al., 2001; Horita et al., 2002; Coggon et al., 2010). Hence ocean crust formed in the Cretaceous was altered in very different thermal and chemical (and biological?) regimes compared to the modern ocean (e.g., Alt and Teagle, 1999). To understand the role of ocean crustal formation and hydrothermal circulation in the global geochemical cycles of modern Earth, it would be sensible to target ocean crust formed in the past 20 to $30 \mathrm{~m}$.y. 


\section{Program considerations for the attainment of deep targets by scientific ocean drilling}

Establishing the ideal location for drilling is only part of the challenge of successfully drilling moderately deep holes $(2-3 \mathrm{~km})$ to recover the samples and data necessary to address long-standing primary goals of scientific ocean drilling. Experience from Holes 504B and 1256D indicates that such experiments require multiple expeditions to achieve their target depths. A total of $\sim 500 \mathrm{~m}$ penetration per expedition is an upper limit for coring in the upper crust, with lesser advances and more frequent drilling challenges as these holes get deeper and rocks metamorphosed at higher pressures and temperatures are encountered (Figs. F8, F9, F10; Tables T1, T3, T4). Penetration and core recovery rates have been low to very low in the two sheeted dike complex sections drilled to date (Holes 504B and 1256D). Average rates of recovery and penetration in the dike section of Hole $1256 \mathrm{D}$ are $32 \%$ and $0.8 \mathrm{~m} / \mathrm{h}$, respectively. The average rate of recovery in the sheeted dike complex of Hole 504B was a miserly 11\%. However, experience to date suggests that gabbroic rocks can be cored relatively rapidly at high rates of recovery (e.g., Hole U1309D: penetration rate $=2 \mathrm{~m} / \mathrm{h}$; recovery $\geq 75 \%$ ), so when the dike-gabbro transition zone is breached, solid progress through the plutonic section can be anticipated.

Long uncased sections through lava flows can result in major problems with wall stability and clearing of drill cuttings as boreholes get deeper. Lava sections are commonly strongly enlarged and out of gauge (>20 inches) for long intervals because of continued spalling of fractured material from the borehole walls. Borehole wall damage is exacerbated by multiple passes of the drill string because of the numerous pipe trips needed to drill a deep hole (e.g., 93 reentries in Hole 504B and 62 reentries in Hole $1256 \mathrm{D}$ as of the end of Expedition 335; Tables T3, T4). Hole intervals with large diameters ( $>12$ inches) greatly reduce the efficiency of high-viscosity mud sweeps to clear deep holes of fine cuttings. The hydraulic horsepower of the lifting fluid is reduced because of velocity decreases and fluid turbulence when mud sweeps leave regions of in-gauge hole and enter more cavernous zones. Hole enlargements also provide cavities where cuttings not swept from the hole can temporarily collect and subsequently become continuously recycled within the borehole.

Although Hole 1256D was established with the infrastructure to install two more casing strings (13 $3 / 8$ inches and 103/4 inches) within the 16 inch casing that was cemented into basement, drilling during
ODP Leg 206 and IODP Expedition 309 proceeded quickly in the upper crust without an apparent need to case the lava sequences to maintain hole stability. However, as Hole $1256 \mathrm{D}$ has been drilled deeper, clearing cuttings from the hole to keep the drill bit clear of debris has become increasingly difficult. Large amounts of coarse-grained basaltic sand were recovered in the fishing tools and the BHA during three consecutive fishing runs while trying to retrieve the broken bit during Expedition 335 (see "Operations" in the "Expedition 335 summary" chapter [Expedition 335 Scientists, 2012]), attesting to the accumulation of cuttings in the hole.

Scientific ocean drilling has little experience in casing long sequences (hundreds of meters) of oceanic basement and a poor armory of underreaming tools for opening hard rock basement holes to the diameters required for the insertion of a casing. For example, the insertion of $13 \%$ inch casing requires reaming an $181 / 2$ inch hole beneath 16 inch casing. Casing hundreds of meters of a deep borehole in igneous basement would be a high risk, costly, and ship-time consuming operation that would produce no new scientific output until completed and drilling was resumed. However, it would greatly improve the stability and hydrodynamics of deep basement boreholes. A regular drilling-then-casing approach to investigate the lower oceanic crust (target depth $=2-3 \mathrm{~km}$ ) will require a long-term commitment by the scientific ocean drilling community to a particular site and experiment and as many as 10 expeditions to complete. The possibility that even such a highly engineered approach could still fail to reach its target would have to be acknowledged and accepted by the community. The development of untethered casing sleeves or targeted wall rock cementing (as tested for the first time during Expedition 335) are options that should be considered. Such approaches might be effective at securing unstable formations and more palatable to a multidisciplinary program with competing science drivers and constant assessment of the outputs. Nevertheless, the potentially transformative science that could be yielded by a deep borehole through the upper crust and down into cumulate gabbro is going to require long-term commitment and investment in time on site, as well as technology and external expertise (e.g., consultant drilling engineers and casing, fishing, cementing, and hardware experts).

It is very unlikely that without significant good fortune deep targets in intact ocean crust can be achieved in the current science advisory configuration. The peer-review system that has overseen the 
progress of both Holes 504B and 1256D has required the reevaluation of new proposals following the successful completion of each drilling increment. A system similar to the "complex drilling proposals" used for riser experiments must be extended to riserless targets that require multiple expeditions to achieve important scientific goals.

Such is the capriciousness of hard rock coring that scientific ocean drilling may have to consider new approaches if it is to ever successfully address some of the major science questions that remain unanswered after more than 50 years. There are unlikely to ever be "quick wins" with targets that require multiexpedition deep boreholes. Expedition 335 was initially scheduled by the IODP-MI Operation Task Force as a short cruise ( $\sim 4$ weeks), despite the explicit recommendations of the postexpedition 309/312 Operational Review Task Force "to maximize on-site time for deep drilling expeditions" (Recommendation 309/312-03; see 309_312_ORTF.PDF in REPORTS in "Supplementary material"). Flexibility in expedition scheduling may be a low-impact means to achieve deep objectives. Back-to-back expeditions to a single target could be scheduled. This approach was successful at drilling Hole U1309D deeper than 1400 mbsf during Expeditions 304 and 305. Commonly, the ship has been moved off a deep hole after the significant investment in engineering and cleaning operations that have succeeded in preparing the hole for deep drilling. For example, Expedition 312 drilled $>100 \mathrm{~m}$ of the dike-plutonic transition zone in Hole $1256 \mathrm{D}$ following significant hole remediation operations but left an open clean deep hole. Five years later, most of Expedition 335 scheduled time was spent on hole remediation. Mechanisms are needed for revising expedition schedules so that drilling can continue in deep boreholes when progress is actually being made. This would require the movement of crew, scientists, and supplies to and from the rig so that drilling and hole cleaning can continue, as well as the temporary postponement of the immediately following expeditions. Clearly, this would be a major departure from the standard operating style of the JOIDES Resolution within ODP and IODP and a challenge to the science advisory and scheduling structure. It would require community acceptance that could be difficult to achieve. However, the present standard " 1 proposal $=1$ expedition" approach is not an effective process to reach targets that require multiple expedition deep drilling. Unless the community and the drilling program are able to develop new approaches to achieving deep targets, the lack of closure on science questions that can only be addressed by deep drilling will continue to stain future renewal documents with a perceived lingering staleness due to a continued recycling of unaccomplished goals.

\section{References}

Alt, J.C., Honnorez, J., Laverne, C., and Emmermann, R., 1986a. Hydrothermal alteration of a $1 \mathrm{~km}$ section through the upper oceanic crust, Deep Sea Drilling Project Hole 504B: mineralogy, chemistry, and evolution of seawater-basalt interactions. J. Geophys. Res., [Solid Earth], 91(B10):10309-10335. doi:10.1029/ JB091iB10p10309

Alt, J.C., Kinoshita, H., Stokking, L.B., et al., 1993. Proc. ODP, Init. Repts., 148: College Station, TX (Ocean Drilling Program). doi:10.2973/odp.proc.ir.148.1993

Alt, J.C., Laverne, C., Vanko, D.A., Tartarotti, P., Teagle, D.A.H., Bach, W., Zuleger, E., Erzinger, J., Honnorez, J., Pezard, P.A., Becker, K., Salisbury, M.H., and Wilkens, R.H., 1996. Hydrothermal alteration of a section of upper oceanic crust in the eastern equatorial Pacific: a synthesis of results from Site 504 (DSDP Legs 69, 70, and 83, and ODP Legs 111, 137, 140, and 148.) In Alt, J.C., Kinoshita, H., Stokking, L.B., and Michael, P.J. (Eds.), Proc. ODP, Sci. Results, 148: College Station, TX (Ocean Drilling Program), 417-434. doi:10.2973/ odp.proc.sr.148.159.1996

Alt, J.C., Muehlenbachs, K., and Honnorez, J., 1986b. An oxygen isotopic profile through the upper kilometer of the oceanic crust, DSDP Hole 504B. Earth Planet. Sci. Lett., 80(3-4):217-229. doi:10.1016/0012821X(86)90106-8

Alt, J.C., and Teagle, D.A.H., 1999. The uptake of carbon during alteration of ocean crust. Geochim. Cosmochim. Acta, 63(10):1527-1535. doi:10.1016/S00167037(99)00123-4

Anderson, R.N., Honnorez, J., Becker, K., et al., 1985. Init. Repts. DSDP, 83: Washington, DC (U.S. Govt. Printing Office). doi:10.2973/dsdp.proc.83.1985

Anonymous, 1972. Penrose field conference on ophiolites. Geotimes, 17:24-25.

Bach, W., and Edwards, K.J., 2003. Iron and sulfide oxidation within the basaltic ocean crust: implications for chemolithoautotrophic microbial biomass production. Geochim. Cosmochim. Acta, 67(20):3871-3887. doi:10.1016/S0016-7037(03)00304-1

Barker, A.K., Coogan, L.A., Gillis, K.M., and Weis, D., 2008. Strontium isotope constraints on fluid flow in the sheeted dike complex of fast-spreading crust: pervasive fluid flow at Pito Deep. Geochem., Geophys., Geosyst., 9(6):Q06010. doi:10.1029/2007GC001901

Bascom, W., 1961. A Hole in the Bottom of the Sea: the Story of the Mohole Project: Garden City, NY (Doubleday).

Becker, K., Foss, G., et al., 1992. Proc. ODP, Init. Repts., 137: College Station, TX (Ocean Drilling Program).

doi:10.2973/odp.proc.ir.137.1992 
Becker, K., Sakai, H., Adamson, A.C., Alexandrovich, J., Alt, J.C., Anderson, R.N., Bideau, D., Gable, R., Herzig, P.M., Houghton, S., Ishizuka, H., Kawahata, H., Kinoshita, H., Langseth, M.G., Lovell, M.A., Malpas, J., Masuda, H., Merrill, R.B., Morin, R.H., Mottl, M.J., Pariso, J.E., Pezard, P., Phillips, J., Sparks, J., and Uhlig, S., 1989. Drilling deep into young oceanic crust, Hole 504B, Costa Rica Rift. Rev. Geophys., 27(1):79-102. doi:10.1029/RG027i001p00079

Becker, K., Sakai, H., et al., 1988. Proc. ODP, Init. Repts., 111: College Station, TX (Ocean Drilling Program). doi:10.2973/odp.proc.ir.111.1988

Bédard, J.H., Sparks, R.S.J., Renner, R., Cheadle, M.J., and Hallworth, M.A., 1988. Peridotite sills and metasomatic gabbros in the eastern layered series of the Rhum complex. J. Geol. Soc. (London, U. K.), 145(2):207-224. doi:10.1144/gsjgs.145.2.0207

Bickle, M.J., and Teagle, D.A.H., 1992. Strontium alteration in the Troodos ophiolite: implications for fluid fluxes and geochemical transport in mid-ocean ridge hydrothermal systems. Earth Planet. Sci. Lett., 113(1-2):219237. doi:10.1016/0012-821X(92)90221-G

Blackman, D.K., Ildefonse, B., John, B.E., Ohara, Y., Miller, D.J., Abe, N., Abratis, M., Andal, E.S., Andreani, M., Awaji, S., Beard, J.S., Brunelli, D., Charney, A.B., Christie, D.M., Collins, J., Delacour, A.G., Delius, H., Drouin, M., Einaudi, F., Escartin, J., Frost, B.R., Früh-Green, G., Fryer, P. B., Gee, J.S., Godard, M., Grimes, C.B., Halfpenny, A., Hansen, H.-E., Harris, A.C., Hayman, N. W., Hellebrand, E., Hirose, T., Hirth, J.G., Ishimaru, S., Johnson, K.T.M., Karner, G.D., Linek, M., MacLeod, C.J., Maeda, J., Mason, O.U., McCaig, A.M., Michibayashi, K., Morris, A., Nakagawa, T., Nozaka, T., Rosner, M., Searle, R.C., Suhr, G., Tominaga, M., von der Handt, A., Yamasaki, T., and Zhao, X., 2011. Drilling constraints on lithospheric accretion and evolution at Atlantis Massif, Mid-Atlantic Ridge $30^{\circ}$ N. J Geophys. Res., [Solid Earth], 116:B07103-B07129. doi:10.1029/ 2010JB007931

Blackman, D.K., Ildefonse, B., John, B.E., Ohara, Y., Miller, D.J., MacLeod, C.J., and the Expedition 304/305 Scientists, 2006. Proc IODP, 304/305: College Station, TX (Integrated Ocean Drilling Program Management International, Inc.). doi:10.2204/iodp.proc.304305.2006

Bosch, D., Jamais, M., Boudier, F., Nicolas, A., Dautria, J.-M., and Agrinier, P., 2004. Deep and high-temperature hydrothermal circulation in the Oman ophiolite-petrological and isotopic evidence. J. Petrol., 45(6):1181-1208. doi:10.1093/petrology/egh010

Boudier, F., Nicolas, A., and Ildefonse, B., 1996. Magma chambers in the Oman ophiolite: fed from the top and the bottom. Earth Planet. Sci. Lett., 144(1-2):239-250. doi:10.1016/0012-821X(96)00167-7

Cande, S.C., and Kent, D.V., 1995. Revised calibration of the geomagnetic polarity timescale for the Late Cretaceous and Cenozoic. J. Geophys. Res., [Solid Earth], 100(B4):6093-6095. doi:10.1029/94JB03098

Cann, J.R., Langseth, M.G., Honnorez, J., Von Herzen, R.P., White, S.M., et al., 1983. Init. Repts. DSDP, 69: Washing- ton, DC (U.S. Govt. Printing Office). doi:10.2973/ dsdp.proc.69.1983

Cannat, M., Cann, J., and Maclennan, J., 2004. Some hard rock constraints on the heat supply to mid-ocean ridges. In German, C.R., Lin, J., and Parson, L.M. (Eds.), Mid-Ocean Ridges: Hydrothermal Interactions Between the Lithosphere and Oceans: Geophys. Monogr. 148:111-149.

Cannat, M., Manatschal, G., Sauter, D., and Péron-Pinvidic, G., 2009. Assessing the conditions of continental breakup at magma-poor rifted margins: what can we learn from slow spreading mid-ocean ridges? C. $R$. Geosci., 341(5):406-427. doi:10.1016/ j.crte.2009.01.005

Cannat, M., Mével, C., Maia, M., Deplus, C., Durand, C., Gente, P., Agrinier, P., Belarouchi, A., Dubuisson, G., Humler, E., and Reynolds, J., 1995. Thin crust, ultramafic exposures, and rugged faulting patterns at the Mid-Atlantic Ridge $\left(22^{\circ}-24^{\circ} \mathrm{N}\right)$. Geology, 23(1):49-52. doi:10.1130/0091-

7613(1995)023<0049:TCUEAR>2.3.CO;2

Caress, D.W., Burnett, M.S., and Orcutt, J.A., 1992. Tomographic image of the axial low-velocity zone at $12^{\circ} 50^{\prime} \mathrm{N}$ on the East Pacific Rise. J. Geophys. Res., [Solid Earth], 97(B6):9243-9263. doi:10.1029/92JB00287

Carlson, R.L., 1998. Seismic velocities in the uppermost oceanic crust: age dependence and the fate of Layer $2 \mathrm{~A}$. J. Geophys. Res., [Solid Earth], 103(B4):7069-7077. doi:10.1029/97JB03577

Carlson, R.L., 2010. How crack porosity and shape control seismic velocities in the upper oceanic crust: modeling downhole logs from Holes 504B and 1256D. Geochem., Geophys., Geosyst., 11(4):Q04007. doi:10.1029/ 2009GC002955

Carlson, R.L., 2011. The effect of hydrothermal alteration on the seismic structure of the upper oceanic crust: evidence from Holes 504B and 1256D., Geochem., Geophys., Geosyst., 12(9):Q09013. doi:10.1029/2011GC003624

Chan, L.-H., Alt, J.C., and Teagle, D.A.H., 2002. Lithium and lithium isotope profiles through the upper oceanic crust: a study of seawater-basalt exchange at ODP Sites 504B and 896A. Earth Planet. Sci. Lett., 201(1):187-201. doi:10.1016/S0012-821X(02)00707-0

Chen, Y.J., and Phipps Morgan, J., 1996. The effects of spreading rate, the magma budget, and the geometry of magma emplacement on the axial heat flux at midocean ridges. J. Geophys. Res., [Solid Earth], 101(B5):11475-11482. doi:10.1029/96JB00330

Christeson, G.L., McIntosh, K.D., and Karson, J.A., 2007. Inconsistent correlation of seismic Layer $2 \mathrm{a}$ and lava layer thickness in oceanic crust. Nature (London, U. K.), 445(7126):418-421. doi:10.1038/nature05517

Coggon, R.M., 2006. Hydrothermal alteration of Macquarie Island: insights from Macquarie Island and drilled in situ ocean crust [Ph.D. thesis]. Univ. Southampton, United Kingdom.

Coggon, R.M., Teagle, D.A.H., Smith-Duque, C.E., Alt, J.C., and Cooper, M.J., 2010. Reconstructing past seawater $\mathrm{Mg} / \mathrm{Ca}$ and $\mathrm{Sr} / \mathrm{Ca}$ from mid-ocean ridge flank calcium 
carbonate veins. Science, 327(5969):1114-1117. doi:10.1126/science.1182252

Coogan, L.A., Howard, K.A., Gillis, K.M., Bickle, M.J., Chapman, H., Boyce, A.J., Jenkin, G.R.T., and Wilson, R.N., 2006. Chemical and thermal constraints on focused fluid flow in the lower oceanic crust. Am. J. Sci., 306(6):389-427. doi:10.2475/06.2006.01

Coogan, L.A., Jenkin, G.R.T., and Wilson, R.N., 2002. Constraining the cooling rate of the lower oceanic crust: a new approach applied to the Oman ophiolite. Earth Planet. Sci. Lett., 199(1-2):127-146. doi:10.1016/S0012821X(02)00554-X

Coogan, L.A., Kasemann, S.A., and Chakraborty, S., 2005. Rates of hydrothermal cooling of new oceanic upper crust derived from lithium geospeedometry. Earth Planet. Sci. Lett., 240(2):415-424. doi:10.1016/ j.epsl.2005.09.020

Coogan, L.A., Manning, C.E., and Wilson., R.N., 2007. Oxygen isotope evidence for short-lived high-temperature fluid flow in the lower oceanic crust at fast-spreading ridges. Earth Planet. Sci. Lett., 260(3-4):524-536. doi:10.1016/j.epsl.2007.06.013

Coumou, D., Driesner, T., and Heinrich, C.A., 2008. The structure and dynamics of mid-ocean ridge hydrothermal systems. Science, 321(5897):1825-1828.

doi:10.1126/science.1159582

Davis, E.E., Becker, K., and He, J., 2004. Costa Rica Rift revisited: constraints on shallow and deep hydrothermal circulation in oceanic crust. Earth Planet. Sci. Lett., 222(3-4):863-879. doi:10.1016/j.epsl.2004.03.032

DeMets, C., Gordon, R.G., and Argus, D.F., 2010. Geologically current plate motions. Geophys. J. Int., 181(1):1-80. doi:10.1111/j.1365-246X.2009.04491.X

Detrick, R., Collins, J., Stephen, R., and Swift, S., 1994. In situ evidence for the nature of the seismic Layer $2 / 3$ boundary in oceanic crust. Nature (London, U. K.), 370(6487):288-290. doi:10.1038/370288a0

Detrick, R., Honnorez, J., Bryan, W.B., Juteau, T., et al., 1988. Proc. ODP, Init. Repts., 106/109: College Station, TX (Ocean Drilling Program). doi:10.2973/ odp.proc.ir.106109.1988

Detrick, R.S., Buhl, P., Vera, E., Mutter, J., Orcutt, J., Madsen, J., and Brocher, T., 1987. Multi-channel seismic imaging of a crustal magma chamber along the East Pacific Rise. Nature (London, U. K.), 326(6108):35-41. doi:10.1038/326035a0

Dick, H.J.B., 1989. Abyssal peridotites, very slow spreading ridges and ocean ridge magmatism. In Saunders, A.D., and Norry, M.J. (Eds.), Magmatism in the Ocean Basins. Geol. Soc. Spec. Publ., 42(1):71-105. doi:10.1144/ GSL.SP.1989.042.01.06

Dick, H.J.B., Erzinger, J., Stokking, L.B., et al., 1992. Proc. ODP, Init. Repts., 140: College Station, TX (Ocean Drilling Program). doi:10.2973/odp.proc.ir.140.1992

Dick, H.J.B., Lin, J., and Schouten, H., 2003. An ultraslowspreading class of ocean ridge. Nature (London, U. K.), 426(6965):405-412. doi:10.1038/nature02128

Dick, H.J.B., and Mével, C., 1996. The Oceanic Lithosphere and Scientific Drilling into the 21st Century: Woods Hole,
MA (JOI/USSSP). http://www.odplegacy.org/PDF/ Admin/Workshops/1996_05_Ocean_Lithosphere.pdf

Dick, H.J.B., Natland, J.H., Alt, J.C., Bach, W., Bideau, D., Gee, J.S., Haggas, S., Hertogen, J.G.H., Hirth, G., Holm, P.M., Ildefonse, B., Iturrino, G.J., John, B.E., Kelley, D.S., Kikawa, E., Kingdon, A., LeRoux, P.J., Maeda, J., Meyer, P.S., Miller, D.J., Naslund, H.R., Niu, Y.-L., Robinson, P.T., Snow, J., Stephen, R.A., Trimby, P.W., Worm, H.-U., and Yoshinobu, A., 2000. A long in situ section of the lower ocean crust: results of ODP Leg 176 drilling at the Southwest Indian Ridge. Earth Planet. Sci. Lett., 179(1):31-51. doi:10.1016/S0012-821X(00)00102-3

Dick, H.J.B., Natland, J.H., and Ildefonse, B., 2006. Past and future impact of deep drilling in the oceanic crust and mantle. Oceanography, 19(4):72-80. doi:10.5670/ oceanog.2006.06

Dick, H.J.B., Natland, J.H., Miller, D.J., et al., 1999. Proc. ODP, Init. Repts., 176: College Station, TX (Ocean Drilling Program). doi:10.2973/odp.proc.ir.176.1999

Donnelly, T., Francheteau, J., Bryan, W., Robinson, P., Flower, M., Salisbury, M., et al., 1980. Init. Repts. DSDP, 51, 52, 53: Washington, DC (U.S. Govt. Printing Office). doi:10.2973/dsdp.proc.515253.1980

Drouin, M., Godard, M., Ildefonse, B., Bruguier, O., and Garrido, C.J., 2009. Geochemical and petrographic evidence for magmatic impregnation in the oceanic lithosphere at Atlantis Massif, Mid-Atlantic Ridge (IODP Hole U1309D, 30N). Chem. Geol., 264(1-4):71-88. doi:10.1016/j.chemgeo.2009.02.013

Drouin, M., Ildefonse, B., and Godard, M., 2010. A microstructural imprint of melt impregnation in slow spreading lithosphere: olivine-rich troctolites from the Atlantis Massif, Mid-Atlantic Ridge, $30^{\circ} \mathrm{N}$, IODP Hole U1309D. Geochem., Geophys., Geosyst., 11(6):Q06003. doi:10.1029/2009GC002995

Dunn, R.A., Toomey, D.R., and Solomon, S.C., 2000. Threedimensional seismic structure and physical properties of the crust and shallow mantle beneath the East Pacific Rise at $9^{\circ} 30^{\prime}$ N. J. Geophys. Res., [Solid Earth], 105(B10):23537-23556. doi:10.1029/2000JB900210

Elderfield, H., and Schultz, A., 1996. Mid-ocean ridge hydrothermal fluxes and the chemical composition of the ocean. Annu. Rev. Earth Planet. Sci., 24(1):191-224. doi:10.1146/annurev.earth.24.1.191

Escartín, J., Smith, D.K., Cann, J., Scouten, H., Langmuir, C.H., and Escrig, S., 2008. Central role of detachment faults in accretion of slow-spreading oceanic lithosphere. Nature (London, U. K.), 455:790-794. doi:10.1038/nature07333

Estabrook, F.B., 1956. Geophysical research shaft. Science, 124(3324):686. doi:10.1126/science.124.3224.686

Expedition 335 Scientists, 2012. Expedition 335 summary. In Teagle, D.A.H., Ildefonse, B., Blum, P., and the Expedition 335 Scientists, Proc. IODP, 335: Tokyo (Integrated Ocean Drilling Program Management International, Inc.). doi:10.2204/iodp.proc.335.101.2012

Fisk, M.R., Giovannoni, S.J., and Thorseth, I.H., 1998. Alteration of oceanic volcanic glass: textural evidence of microbial activity. Science, 281(5379):978-980. doi:10.1126/science.281.5379.978 
Francheteau, J., Armijo, R., Cheminée, J.L., Hekinian, R., Lonsdale, P., and Blum, N., 1992. Dyke complex of the East Pacific Rise exposed in the walls of Hess Deep and the structure of the upper oceanic crust. Earth Planet. Sci. Lett., 111(1):109-121. doi:10.1016/ 0012-821X(92)90173-S

Garrido, C.J., Kelemen, P.B., and Hirth, G., 2001. Variation of cooling rate with depth in lower crust formed at an oceanic spreading ridge: plagioclase crystal size distributions in gabbros from the Oman ophiolite. Geochem., Geophys., Geosyst., 2(10):1041-1072. doi:10.1029/ 2000GC000136

Gee, J.S., and Kent, D.V., 2007. Source of oceanic magnetic anomalies and the geomagnetic polarity timescale. In Kono, M. (Ed.), Treatise on Geophysics: Geomagnetism (Vol. 5): Amsterdam (Elsevier), 455-507.

Gillis, K., Mével, C., Allan, J., et al., 1993. Proc. ODP, Init. Repts., 147: College Station, TX (Ocean Drilling Program). doi:10.2973/odp.proc.ir.147.1993

Gillis, K.M., Coogan, L.A., and Pedersen, R., 2005. Strontium isotope constraints on fluid flow in the upper oceanic crust at the East Pacific Rise. Earth Planet. Sci. Lett., 232(1-2):83-94. doi:10.1016/j.epsl.2005.01.008

Godard, M., Awaji, S., Hansen, H., Hellebrand, E., Brunelli, D., Johnson, K., Yamasaki, T., Maeda, J., Abratis, M., Christie, D., Kato, Y., Mariet, C., and Rosner, M., 2009. Geochemistry of a long in-situ section of intrusive slowspread oceanic lithosphere: results from IODP Site U1309 (Atlantis Massif, $30^{\circ} \mathrm{N}$ Mid-Atlantic-Ridge). Earth Planet. Sci. Lett., 279(1-2):110-122. doi:10.1016/ j.epsl.2008.12.034

Greenberg, D.S., 1974. MoHole: geopolitical fiasco. In Gass, G., Smith, P.J., and Wilson, R.C.L. (Eds.), Understanding the Earth: A Reader in the Earth Sciences: Maidenhead, U.K. (Open Univ. Press), 343-348.

Gregg, T.K.P., and Chadwick, W.W., Jr., 1996. Submarine lava-flow inflation: a model for the formation of lava pillars. Geology, 24(11):981-984. doi:10.1130/00917613(1996)024<0981:SLFIAM>2.3.CO;2

Gregg, T.K.P., and Fink, J.H., 1995. Quantification of submarine lava-flow morphology through analog experiments. Geology, 23(1):73-76. doi:10.1130/ 0091-7613(1995)023<0073:QOSLFM>2.3.CO;2

Gregory, R.T., and Taylor, H.P., Jr., 1981. An oxygen isotope profile in a section of Cretaceous oceanic crust, Samail ophiolite, Oman: evidence for $\delta^{18} \mathrm{O}$ buffering of the oceans by deep ( $>5 \mathrm{~km}$ ) seawater-hydrothermal circulation at mid-ocean ridges. J. Geophys. Res., [Solid Earth], 86(B4):2737-2755. doi:10.1029/JB086iB04p02737

Harris, M., 2011. The accretion of lower oceanic crust [Ph.D. thesis]. Univ. Southampton, United Kingdom. http://eprints.soton.ac.uk/195039/

Harris, M., Smith-Duque, C.E., Teagle, D.A., Cooper, M.J., Coggon, R.M., and Foley, L., 2008. A whole rock strontium isotopic profile through an intact section of upper oceanic crust: ODP Site 1256. Eos, Trans. Am. Geophys. Union, 89(53)(Suppl.):V44B-07. (Abstract) http:// www.agu.org/meetings/fm08/waisfm08.html

Henstock, T.J., Woods, A.W., and White, R.S., 1993. The accretion of oceanic crust by episodic sill intrusion. $J$.
Geophys. Res., [Solid Earth], 98(B3):4143-4161.

doi:10.1029/92JB02661

Honnorez, J., Von Herzen, R.P., et al., 1983. Init. Repts. DSDP, 70: Washington, DC (U.S. Govt. Printing Office). doi:10.2973/dsdp.proc.70.1983

Horita, J., Zimmerman, H., and Holland, H.D., 2002. Chemical evolution of seawater during the Phanerozoic: implications from the record of marine evaporites. Geochim. Cosmochim. Acta, 66(21):3733-3756. doi:10.1016/S0016-7037(01)00884-5

Hussenoeder, S.A., Collins, J.A., Kent, G.M., Detrick, R.S., and the TERA Group, 1996. Seismic analysis of the axial magma chamber reflector along the southern East Pacific Rise from conventional reflection profiling. J. Geophys. Res., [Solid Earth], 101(B10):22087-22105. doi:10.1029/96JB01907

Ildefonse, B., Abe, N., Blackman, D.K., Canales, J.P., Isozaki, Y., Kodaira, S., Myers, G., Nakamura, K., Nedimovic, M., Seama, N., Skinner, A., Takazawa, E., Teagle, D.A.H., Tominaga, M., Umino, S., Wilson, D.S., and Yamao, M., 2010a. The MoHole: A Crustal Journey and Mantle Quest Workshop Report. http://campanian.iodp.org/MoHole/MoHoleWS2010_Report.pdf

Ildefonse, B., Abe, N., Blackman, D.K., Canales, J.P., Isozaki, Y., Kodaira, S., Myers, G., Nakamura, K., Nedimovic, M., Skinner, A.C., Seama, N., Takazawa, E., Teagle, D.A.H., Tominaga, M., Umino, S., Wilson, D.S., and Yamao, M., 2010b. The MoHole: a crustal journey and mantle quest, workshop in Kanazawa, Japan, 3-5 June 2010. Sci. Drill., 10:56-62. doi:10.2204/ iodp.sd.10.07.2010

Ildefonse, B., Blackman, D.K., John, B.E., Ohara, Y., Miller, D.J., MacLeod, C.J., and Integrated Ocean Drilling Program Expeditions 304/305 Science Party, 2007a. Oceanic core complexes and crustal accretion at slowspreading ridges. Geology, 35(7):623-626. doi:10.1130/ G23531A.1

Ildefonse, B., Christie, D.M., and the Mission Moho Workshop Steering Committee, 2007b. Mission Moho workshop: drilling through the oceanic crust to the mantle. Sci. Drill., 4:11-18. doi:10.2204/iodp.sd.4.02.2007

Ildefonse, B., Rona, P.A., and Blackman, D.K., 2007c. Drilling the crust at mid-ocean ridges: an "in depth" perspective. Oceanography, 20(1):66-77. http:// www.tos.org/oceanography/issues/issue_archive/ issue_pdfs/20_1/20.1_ildefonse_et_al.pdf

Jupp, T., and Schultz, A., 2000. A thermodynamic explanation for black smoker temperatures. Nature (London, $U$. K.), 403(6772):880-883. doi:10.1038/35002552

Karson, J.A., 2002. Geologic structure of the uppermost oceanic crust created at fast- to intermediate-rate spreading centers. Annu. Rev. Earth Planet. Sci., 30:347384. doi:10.1146/annurev.earth.30.091201.141132

Karson, J.A., Hurst, S.D., and Lonsdale, P., 1992. Tectonic rotations of dikes in fast-spread oceanic crust exposed near Hess Deep. Geology, 20(8):685-688. doi:10.1130/ 0091-7613(1992)020<0685:TRODIF $>2.3$. CO;2

Kelemen, P.B., and Aharonov, E., 1998. Periodic formation of magma fractures and generation of layered gabbros in the lower crust beneath oceanic spreading ridges. In 
Buck, R., Delaney, P.T., Karson, J.A., and Lagabrielle, Y. (Eds.), Faulting and Magmatism at Mid-Ocean Ridges. Geophys. Monogr., 106:267-289. doi:10.1029/ GM106p0267

Kelemen, P.B., Kikawa, E., Miller, D.J., et al., 2004. Proc. ODP, Init. Repts., 209: College Station, TX (Ocean Drilling Program). doi:10.2973/odp.proc.ir.209.2004

Kelemen, P.B., Koga, K., and Shimizu, N., 1997. Geochemistry of gabbro sills in the crust-mantle transition zone of the Oman ophiolite: implications for the origin of the oceanic lower crust. Earth Planet. Sci. Lett., 146(34):475-488. doi:10.1016/S0012-821X(96)00235-X

Kent, G.M., Harding, A.J., Orcutt, J.A., Detrick, R.S., Mutter, J.C., and Buhl, P., 1994. Uniform accretion of oceanic crust south of the Garrett transform at $14^{\circ} 15^{\prime} \mathrm{S}$ on the East Pacific Rise. J. Geophys. Res., [Solid Earth], 99(B5):9097-9116. doi:10.1029/93JB02872

Kikawa, E., and Ozawa, K., 1992. Contribution of oceanic gabbros to seafloor spreading magnetic anomalies. Science, 258(5083):796-799. doi:10.1126/science.258.5083.796

Klein, E.M., and Langmuir, C.H., 1987. Global correlations of ocean ridge basalt chemistry with axial depth and crustal thickness. J. Geophys. Res., [Solid Earth], 92(B8):8089-8115. doi:10.1029/JB092iB08p08089

Korenaga, J., and Kelemen, P.B., 1997. Origin of gabbro sills in the Moho transition zone of the Oman ophiolite: implications for magma transport in the oceanic lower crust. J. Geophys. Res., [Solid Earth], 102(B12):27729-27749. doi:10.1029/97JB02604

Lancelot, Y., Larson, R., et al. 1990. Proc. ODP, Init. Repts., 129: College Station, TX (Ocean Drilling Program). doi:10.2973/odp.proc.ir.129.1990

Leinen, M., Rea, D.K., et al., 1986. Init. Repts. DSDP, 92: Washington, DC (U.S. Govt. Printing Office). doi:10.2973/dsdp.proc.92.1986

Lissenberg, C.J., and Dick, H.J.B., 2008. Melt-rock reaction in the lower oceanic crust and its implications for the genesis of mid-ocean ridge basalt. Earth Planet. Sci. Lett., 271(1-4):311-325. doi:10.1016/j.epsl.2008.04.023

Lister, C.R.B., 1972. On the thermal balance of a midocean ridge. Geophys. J. R. Astron. Soc., 26(5):515-535. doi:10.1111/j.1365-246X.1972.tb05766.X

Lowenstein, T.K., Timofeeff, M.N., Brennan, S.T., Hardie, L.A., and Demicco, R.V., 2001. Oscillations in Phanerozoic seawater chemistry: evidence from fluid inclusions. Science, 294(5544):1086-1088. doi:10.1126/science. 1064280

Maclennan, J., Hulme, T., and Singh, S.C., 2005. Cooling of the lower oceanic crust. Geology, 33(5):357-366. doi:10.1130/G21207.1

MacLeod, C.J., and Yaouancq, G., 2000. A fossil melt lens in the Oman ophiolite: implications for magma chamber processes at fast spreading ridges. Earth Planet. Sci. Lett., 176(3-4):357-373. doi:10.1016/S0012821X(00)00020-0

Mason, O.U., Nakagawa, T., Rosner, M., Van Nostrand, J.D., Zhou, J., Maruyama, A., Fisk, M.R., and Giovannoni, S.J., 2010. First investigation of the microbiology of the deepest layer of ocean crust. PLoS One, 5(11):e15399. doi:10.1371/journal.pone.0015399

McCarthy, M.D., Beaupré, S.R., Walker, B.D., Voparil, I., Guilderson, T.P., and Druffel, E.R.M., 2011. Chemosynthetic origin of ${ }^{14} \mathrm{C}$-depleted dissolved organic matter in a ridge-flank hydrothermal system. Nat. Geosci., 4(1):32-36. doi:10.1038/ngeo1015

McKenzie, D., and Bickle, M.J., 1988. The volume and composition of melt generated by extension of the lithosphere. J. Petrol., 29(3):625-679. doi:10.1093/petrology/29.3.625

McLoughlin, N., Furnes, H., Banerjee, N.R., Muehlenbachs, K., and Staudigel, H., 2009. Ichnotaxonomy of microbial trace fossils in volcanic glass. J. Geol. Soc., 166(1):159-169. doi:10.1144/0016-76492008-049

Miyashiro, A., 1973. The Troodos ophiolitic complex was probably formed in an island arc. Earth Planet. Sci. Lett., 19(2):218-224. doi:10.1016/0012-821X(73)90118-0

Miyashita, S., Adachi, Y., and Umino, S., 2003. Along-axis magmatic system in the northern Oman ophiolite: implications of compositional variation of the sheeted dike complex. Geochem., Geophys., Geosyst., 4(9):8617. doi:10.1029/2001GC000235

Mottl, M.J., 1983. Metabasalts, axial hot springs, and the structure of hydrothermal systems at mid-ocean ridges. Geol. Soc. Am. Bull., 94(2):161-180. doi:10.1130/ 0016-7606(1983)94<161:MAHSAT>2.0.CO;2

Müller, R.D., Sdrolias, M., Gaina, C., and Roest, W.R., 2008. Age, spreading rates, and spreading asymmetry of the world's ocean crust. Geochem., Geophys., Geosyst., 9(4):Q04006. doi:10.1029/2007GC001743

Murray, R.W., Schrag, D.P., and Wheat, C.G., 2002. Opportunities in Geochemistry for Post-2003 Ocean Drilling: Washington, DC (Joint Oceanographic Institutions, Inc.).

Natland, J.H., and Dick, H.J.B., 2009. Paired melt lenses at the East Pacific Rise and the pattern of melt flow through the gabbroic layer at a fast-spreading ridge. Lithos, 112(1-2):73-86. doi:10.1016/ j.lithos.2009.06.017

Nielsen, S.G., Rehkämper, M., Teagle, D.A.H., Butterfield, D.A., Alt, J.C., and Halliday, A.N., 2006. Hydrothermal fluid fluxes calculated from the isotopic mass balance of thallium in the ocean crust. Earth Planet. Sci. Lett., 251(1-2):120-133. doi:10.1016/j.epsl.2006.09.002

Palmer, M.R., and Edmond, J.M., 1989. The strontium isotope budget of the modern ocean. Earth Planet. Sci. Lett., 92(1):11-26. doi:10.1016/0012-821X(89)90017-4

Pariso, J.E., and Johnson, H.P., 1993. Do Layer 3 rocks make a significant contribution to marine magnetic anomalies? In situ magnetization of gabbros at Ocean Drilling Program Hole 735B. J. Geophys. Res., [Solid Earth], 98(B9):16033-16052. doi:10.1029/93JB01097

Phipps Morgan, J., and Chen, Y.J., 1993. The genesis of oceanic crust: magma injection, hydrothermal circulation, and crustal flow. J. Geophys. Res., [Solid Earth], 98(B4):6283-6297. doi:10.1029/92JB02650

Plank, T., Ludden, J.N., Escutia, C., et al., 2000. Proc. ODP, Init. Repts., 185: College Station, TX (Ocean Drilling Program). doi:10.2973/odp.proc.ir.185.2000 
Quick, J.E., and Denlinger, R.P., 1993. Ductile deformation and the origin of layered gabbro in ophiolites. J. Geophys. Res., [Solid Earth], 98(B8):14015-14027. doi:10.1029/93JB00698

Rautenschlein, M., Jenner, G.A., Hertogen, J., Hofmann, A.W., Kerrich, R., Schminke, H.-U., and White, W.M., 1985. Isotopic and trace element composition of volcanic glasses from the Akaki Canyon, Cyprus: implications for the origin of the Troodos ophiolite. Earth Planet. Sci. Lett., 75(4):369-383. doi:10.1016/0012821X(85)90180-3

Ravelo, C., Bach, W., Behrmann, J., Camoin, G., Duncan, R., Edwards, K., Gulick, S., Inagaki, F., Pälike, H., and Tada, R., 2010. INVEST Report: IODP New Ventures in Exploring Scientific Targets-Defining New Goals of an International Drilling Program: Tokyo (IODP-MI). http:// www.ecord.org/rep/INVEST-Report.pdf

Robinson, P.T., Von Herzen, R., et al., 1989. Proc. ODP, Init. Repts., 118: College Station, TX (Ocean Drilling Program). doi:10.2973/odp.proc.ir.118.1989

Rosendahl, B.R., Hekinian, R., et al., 1980. Init. Repts. DSDP, 54: Washington, DC (U.S. Govt. Printing Office). doi:10.2973/dsdp.proc.54.1980

Rouxel, O., Ono, S., Alt, J., Rumble, D., and Ludden, J., 2008. Sulfur isotope evidence for microbial sulfate reduction in altered oceanic basalts at ODP Site 801 . Earth Planet. Sci. Lett., 268(1-2):110-123. doi:10.1016/ j.epsl.2008.01.010

Rubin, K.H., and Sinton, J.M., 2007. Inferences on midocean ridge thermal and magmatic structure from MORB compositions. Earth Planet. Sci. Lett., 260(12):257-276. doi:10.1016/j.epsl.2007.05.035

Santelli, C.M., Orcutt, B.N., Banning, E., Bach, W., Moyer, C.L., Sogin, M.L., Staudigel. H., and Edwards, K.J., 2008. Abundance and diversity of microbial life in ocean crust. Nature (London, U. K.), 453(7195):653-656. doi:10.1038/nature06899

Seyfried, W.E., Jr., Ding, K., Berndt, M.E., and Chen, X., 1999. Experimental and theoretical controls on the composition of mid-ocean ridge hydrothermal fluids. In Barrie, C.T., and Hannington, M.D. (Eds.), Volcanic Associated Massive Sulfide Deposits: Processes and Examples in Modern and Ancient Settings. Rev. Econ. Geol., 8:181-200.

Shipboard Scientific Party, 1986. Site 504. In Leinen, M., Rea, D.K., et al., Init. Repts. DSDP, 92: Washington, DC (U.S. Govt. Printing Office), 187-214. doi:10.2973/ dsdp.proc.92.106.1986

Shipboard Scientific Party, 1988. Site 504: Costa Rica Rift. In Becker, K., Sakai, H., et al., Proc. ODP, Init. Repts., 111: College Station, TX (Ocean Drilling Program), 35-251. doi:10.2973/odp.proc.ir.111.103.1988

Shipboard Scientific Party, 1992a. Site 504. In Becker, K., Foss, G., et al., Proc. ODP, Init. Repts., 137: College Station, TX (Ocean Drilling Program), 15-55. doi:10.2973/ odp.proc.ir.137.102.1992

Shipboard Scientific Party, 1992b. Site 504. In Dick, H.J.B., Erzinger, J., Stokking, L.B., et al., Proc. ODP, Init. Repts.,
140: College Station, TX (Ocean Drilling Program), 37200. doi:10.2973/odp.proc.ir.140.102.1992

Shipboard Scientific Party, 1993. Site 504. In Alt, J.C., Kinoshita, H., Stokking, L.B., et al., Proc. ODP, Init. Repts., 148: College Station, TX (Ocean Drilling Program), 27-121. doi:10.2973/odp.proc.ir.148.102.1993

Shipboard Scientific Party, 1999. Site 735. In Dick, H.J.B., Natland, J.H., Miller, D.J., et al., Proc. ODP, Init. Repts., 176: College Station, TX (Ocean Drilling Program), 1314. doi:10.2973/odp.proc.ir.176.103.1999

Shor, E.N., 1985. A chronology from Mohole to JOIDES. In Drake, E.T., and Jordan, W.M. (Eds.), Geologists and Ideas: A History of North American Geology (Centennial Special Vol. 1): Boulder (Geol. Soc. Am.), 4:391-399.

Singh, S.C., Kent, G.M., Collier, J.S., Harding, A.J., and Orcutt, J.A., 1998. Melt to mush variations in crustal magma properties along the ridge crest at the southern East Pacific Rise. Nature (London, U. K.), 394(6696):874878. doi:10.1038/29740

Sinton, J.M., and Detrick, R.S., 1992. Mid-ocean ridge magma chambers. J. Geophys. Res., [Solid Earth], 97(B1):197-216. doi:10.1029/91JB02508

Sleep, N.H., 1975. Formation of oceanic crust: some thermal constraints. J. Geophys. Res., [Solid Earth], 80(29):4037-4042. doi:10.1029/JB080i029p04037

Stanley, S.M., and Hardie, L.A., 1998. Secular oscillations in the carbonate mineralogy of reef-building and sediment-producing organisms driven by tectonically forced shifts in seawater chemistry. Palaeogeogr., Palaeoclimatol., Palaeoecol., 144(1-2):3-19. doi:10.1016/ S0031-0182(98)00109-6

Stein, C.A., and Stein, S., 1994. Constraints on hydrothermal heat flux through the oceanic lithosphere from global heat flow. J. Geophys. Res., [Solid Earth], 99(B2):3081-3095. doi:10.1029/93JB02222

Stern, R.J., 2004. Subduction initiation: spontaneous and induced. Earth Planet. Sci. Lett., 226(3-4):275-292. doi:10.1016/j.epsl.2004.08.007

Storms, M.A., Batiza, R., et al., 1993. Proc. ODP, Init. Repts., 142: College Station, TX (Ocean Drilling Program). doi:10.2973/odp.proc.ir.142.1993

Suhr, G., Hellebrand, E., Johnson, K., and Brunelli, D., 2008. Stacked gabbro units and intervening mantle: a detailed look at a section of IODP Leg 305, Hole U1309D. Geochem., Geophys., Geosyst., 9(10):Q10007. doi:10.1029/2008GC002012

Teagle, D., and Ildefonse, B., 2011. Journey to the mantle of the Earth. Nature (London, U. K.), 471(7339):437-439. doi:10.1038/471437a

Teagle, D., Ildefonse, B., Blackman, D., Edwards, K., Bach, W., Abe, N., Coggon, R., and Dick, H., 2009. Melting, Magma, Fluids and Life-Challenges for the Next Generation of Scientific Ocean Drilling into the Oceanic Lithosphere: Workshop Report: Southampton (Univ. Southampton).

Teagle, D.A.H., Alt, J.C., and Halliday, A.N., 1998a. Tracing the chemical evolution of fluids during hydrothermal 
recharge: constraints from anhydrite recovered in ODP Hole 504B. Earth Planet. Sci. Lett., 155(3-4):167-182. doi:10.1016/S0012-821X(97)00209-4

Teagle, D.A.H., Alt, J.C., and Halliday, A.N., 1998b. Tracing the evolution of hydrothermal fluids in the upper oceanic crust: Sr-isotopic constraints from DSDP/ODP Holes 504B and 896A. In Harrison, K., and Mills, R.A. (Eds.), Modern Ocean Floor Processes and the Geological Record. Geol. Soc. Spec. Publ., 148(1):81-97. doi:10.1144/GSL.SP.1998.148.01.06

Teagle, D.A.H., Alt, J.C., Umino, S., Miyashita, S., Banerjee, N.R., Wilson, D.S., and the Expedition 309/312 Scientists, 2006. Proc. IODP, 309/312: Washington, DC (Integrated Ocean Drilling Program Management International, Inc.). doi:10.2204/ iodp.proc.309312.2006

Teagle, D.A.H., Bickle, M.J., and Alt, J.C., 2003. Recharge flux to ocean-ridge black smoker systems: a geochemical estimate from ODP Hole 504B. Earth Planet. Sci. Lett., 210(1-2):81-89. doi:10.1016/S0012-821X(03)00126-2

Teagle, D.A.H., Wilson, D.S., and Acton, G.D., 2004. The "road to the MoHole" four decades on: deep drilling at Site 1256. Eos, Trans. Am. Geophys. Union, 85(49):521. doi:10.1029/2004E0490002

Umino, S., Lipman, P.W., and Obata, S., 2000. Subaqueous lava flow lobes, observed on ROV Kaiko dives off Hawaii. Geology, 28(6):503-506. doi:10.1130/00917613(2000)28<503:SLFLOO>2.0.CO;2

Vance, D., Teagle, D.A.H., and Foster, G.L., 2009. Variable Quaternary chemical weathering fluxes and imbalances in marine geochemical budgets. Nature (London, U. K.), 458(7237):493-496. doi:10.1038/nature07828

Van Tongeren, J.A., Kelemen, P.B., and Hanghøj, K., 2008. Cooling rates in the lower crust of the Oman ophiolite: Ca in olivine, revisited. Earth Planet. Sci. Lett., 267(12):69-82. doi:10.1016/j.epsl.2007.11.034

Vera, E.E., Mutter, J.C., Buhl, P., Orcutt, J.A., Harding, A.J., Kappus, M.E., Detrick, R.S., and Brocher, T.M., 1990. The structure of 0- to $0.2-\mathrm{m}$.y.-old oceanic crust at $9^{\circ} \mathrm{N}$ on the East Pacific Rise from expanded spread profiles. $J$. Geophys. Res., [Solid Earth], 95(B10):15529-15556. doi:10.1029/JB095iB10p15529
Vine, F.J., and Matthews, D.H., 1963. Magnetic anomalies over a young oceanic ridge off Vancouver Island. Nature (London, U. K.), 199(4897):947-949. doi:10.1038/ $199947 \mathrm{a} 0$

Von Herzen, R.P., 2004. Geothermal evidence for continuing hydrothermal circulation in older (>60 m.y.) ocean crust. In Davis, E.E., and Elderfield, H. (Eds.) Hydrogeology of the Oceanic Lithosphere: Cambridge (Cambridge Univ. Press), 414-447.

Waggoner, D.G., 1993. The age and alteration of central Pacific oceanic crust near Hawaii, Site 843. In Wilkens, R.H., Firth, J., Bender, J., et al., Proc. ODP, Sci. Results, 136: College Station, TX (Ocean Drilling Program), 119132. doi:10.2973/odp.proc.sr.136.212.1993

Wheat, C.G., and Fisher, A.T., 2008. Massive, low-temperature hydrothermal flow from a basaltic outcrop on 23 Ma seafloor of the Cocos plate: chemical constraints and implications. Geochem., Geophys., Geosyst., 9(12):Q12O14. doi:10.1029/2008GC002136

Wilson, D.S., Teagle, D.A.H., Acton, G.D., et al., 2003. Proc. ODP, Init. Repts., 206: College Station, TX (Ocean Drilling Program). doi:10.2973/odp.proc.ir.206.2003

Wilson, D.S., Teagle, D.A.H., Alt, J.C., Banerjee, N.R., Umino, S., Miyashita, S., Acton, G.D., Anma, R., Barr, S.R., Belghoul, A., Carlut, J., Christie, D.M., Coggon, R.M., Cooper, K.M., Cordier, C., Crispini, L., Durand, S.R., Einaudi, F., Galli, L., Gao, Y., Geldmacher, J., Gilbert, L.A., Hayman, N.W., Herrero-Bervera, E., Hirano, N., Holter, S., Ingle, S., Jiang, S., Kalberkamp, U., Kerneklian, M., Koepke, J., Laverne, C., Vasquez, H.L.L., Maclennan, J., Morgan, S., Neo, N., Nichols, H.J., Park, S.-H., Reichow, M.K., Sakuyama, T., Sano, T., Sandwell, R., Scheibner, B., Smith-Duque, C.E., Swift, S.A., Tartarotti, P., Tikku, A.A., Tominaga, M., Veloso, E.A., Yamasaki, T., Yamazaki, S., and Ziegler, C., 2006. Drilling to gabbro in intact ocean crust. Science, 312(5776):1016-1020. doi:10.1126/science.1126090

Publication: 3 June 2012

MS 335-104 
Figure F1. Distribution of spreading rates for major active plate boundaries, presented (A) in histogram form and (B) as cumulative distribution. Rates are the best-fit rates of the MORVEL model (DeMets et al., 2010), and ridge length is measured as the component perpendicular to spreading direction. Horizontal lines on the cumulative plot show the range of spreading rate for each plate pair, with line width scaled approximately to plate boundary length. Plate-pair labels follow the MORVEL (mid-ocean ridge velocities) convention, except in the Indian Ocean where the southeast, southwest, and northwest branches of the ridge system are grouped for 23 plate pairs to simplify labeling. $\mathrm{NB}=$ Nubia plate, $\mathrm{SA}=$ South America plate, $\mathrm{NZ}=$ Nazca plate, $\mathrm{PA}=$ Pacific plate, $\mathrm{NA}=$ North America plate, $\mathrm{CO}=$ Cocos plate, $\mathrm{EU}=$ Eurasian plate, SWIR $=$ Southwest Indian Ridge, SEIR $=$ Southeast Indian Ridge, $\mathrm{AN}=$ Antarctic plate, $\mathrm{AR}=$ Arabia plate, $\mathrm{SM}=$ Somalia plate, $\mathrm{RI}=$ Rivera plate, NWIR $=$ Northwest Indian Ridge, JF $=$ Juan de Fuca plate.
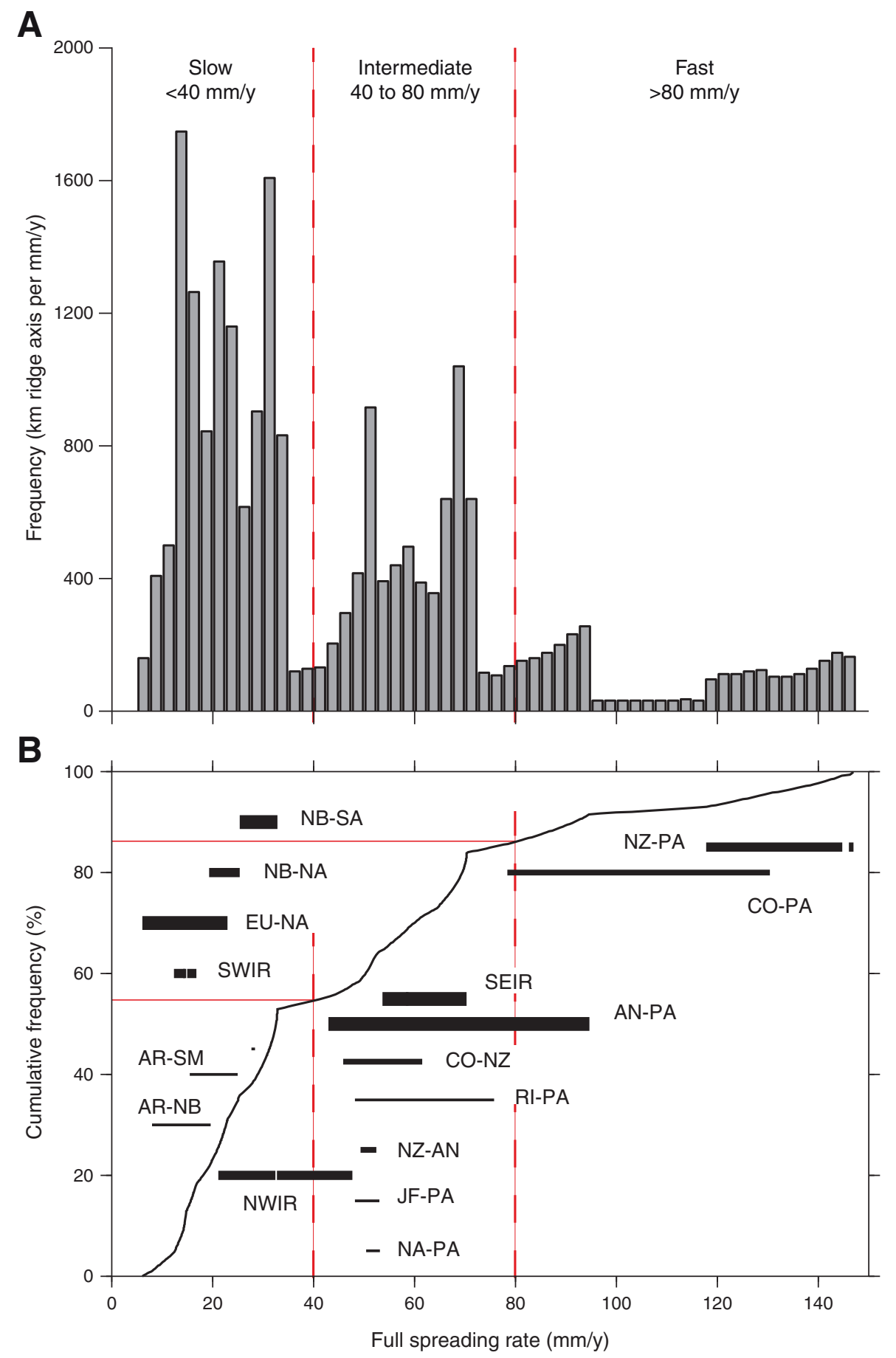
Figure F2. A. Global view of ocean crust colored by spreading rate at time of formation, based on age and spreading rate grids by Müller et al. (2008), revised version 3 (www.earthbyte.org/). B. Histogram comparing the proportions of the present-day ocean crust that formed at slow, intermediate, and fast spreading rates, based on the rate grid plotted in A. Tabulation includes variation of grid-cell area with latitude. Labeled spreading rates are twice the half rate for comparison with full rates.
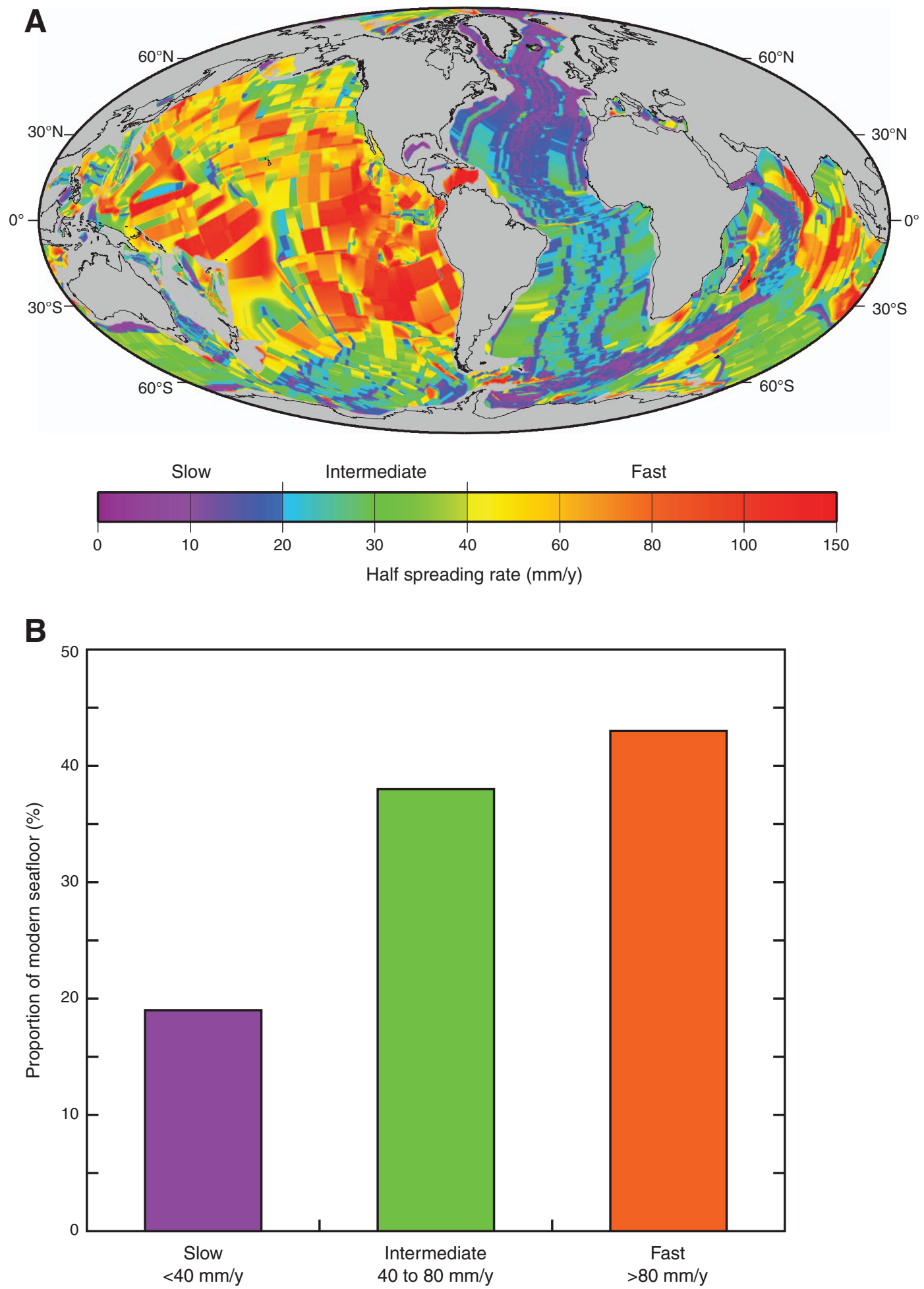
Figure F3. A. Contour map of seismic $P$-wave velocity at the top of basement in the Site 1256 area, based on tomographic inversion of seismic refraction data (A.J. Harding, pers. comm., 2005). The low-velocity area west of the center may reflect pillow lavas or other porous formation. The high-velocity area extending southeast from Site 1256 may reflect the extent of the ponded lava sequence drilled at the top of Site 1256 . OBH $=$ ocean bottom hydrophone. B. Geological sketch map of the Site 1256 area (GUATB-03) showing bathymetry, alternate site locations, and selected top-of-basement velocity contours from A. The larger velocity contour line partially encloses velocity $>4.82 \mathrm{~km} / \mathrm{s}$, which we interpret as a plausible proxy for the presence of thick ponded lava flows, as encountered at Site 1256. The smaller contour encloses velocities $<4.60 \mathrm{~km} / \mathrm{s}$, possibly reflecting a greater portion of pillow lavas than elsewhere in the region. Alternate reentry Sites 3D and 3E are 0.5-1.0 km from Site 1256 and are not shown in the figure. MCS = multichannel seismic.
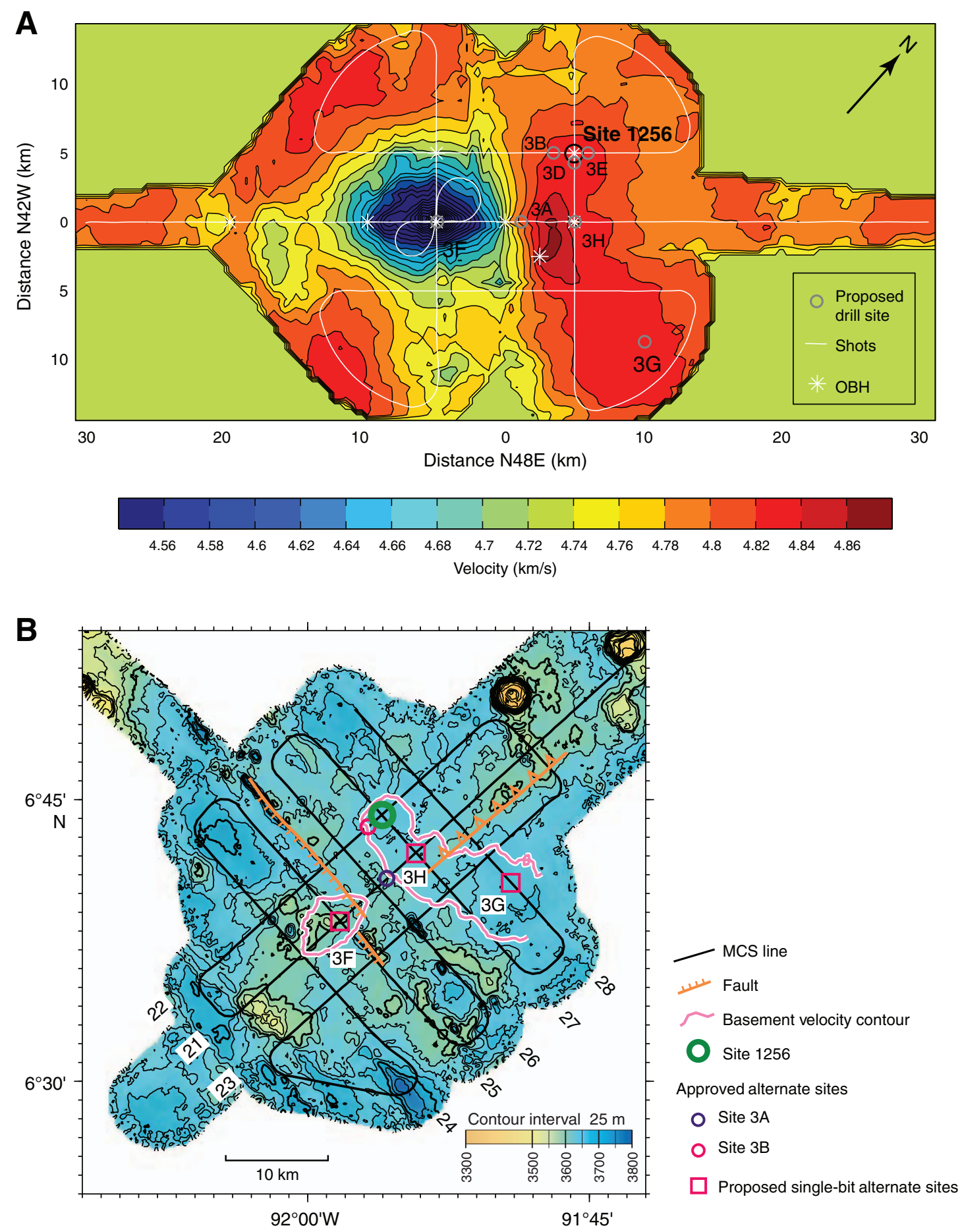
Figure F4. Schematic drawings of crustal accretion models (modified from Korenaga and Kelemen, 1997). Black arrows show the movement of the solid lower crust; blue arrows show the dominant zones where hydrothermal circulation will remove latent and sensible heat; red arrows show the movement of magma-this is unknown in all models. A. Gabbro glacier ductile flow model (e.g., Henstock et al., 1993; Phipps Morgan and Chen, 1993; Quick and Denlinger, 1993). Ductile flow down and outward from a high-level axial magma chamber constructs the lower crust. B. Hybrid model of ductile flow with sill intrusions (e.g., Boudier et al., 1996). C. "Sheeted" or "stacked" sill model of in situ formation of the lower crust by on-axis sill intrusions (e.g., Bédard et al., 1988; Kelemen and Aharonov, 1998; Kelemen et al., 1997; MacLeod and Yoauancq, 2000). D. Schematic relative variations in the general trends of latent heat release, bulk Mg\#, strain rate, cooling rate, hydrothermal fluid flux, fluid temperature, and intensity of high-temperature (HT) alteration with depth predicted by end-member "gabbro glacier" (with mainly conductive cooling of the lower crust) and "sheeted sill" (with convective cooling of the lower crust) models of crustal accretion (original figure by R. Coggon).
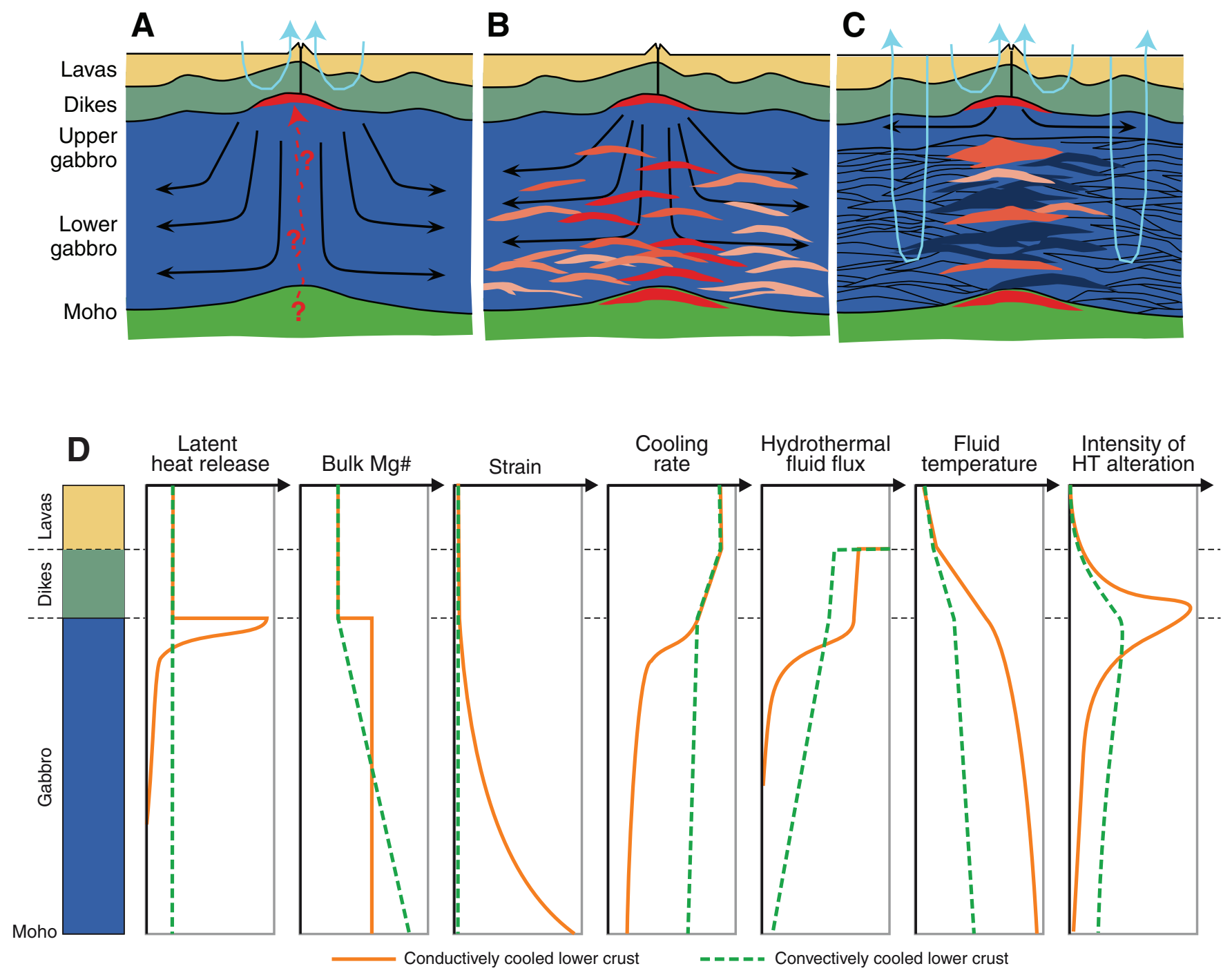
Figure F5. Map of ocean floor age, based on age grid by Müller et al. (2008), revised version 3 (www.earthbyte.org/). Symbols represent DSDP, ODP, and IODP holes drilled in ocean crust $>100$ mbsf from 1974 to 2011 . Holes deeper than $500 \mathrm{~m}$ in intact and rifted oceanic crust are labeled. This map does not include "hard rock" drill holes in oceanic plateaus, arc basement, hydrothermal mounds, or passive margins.

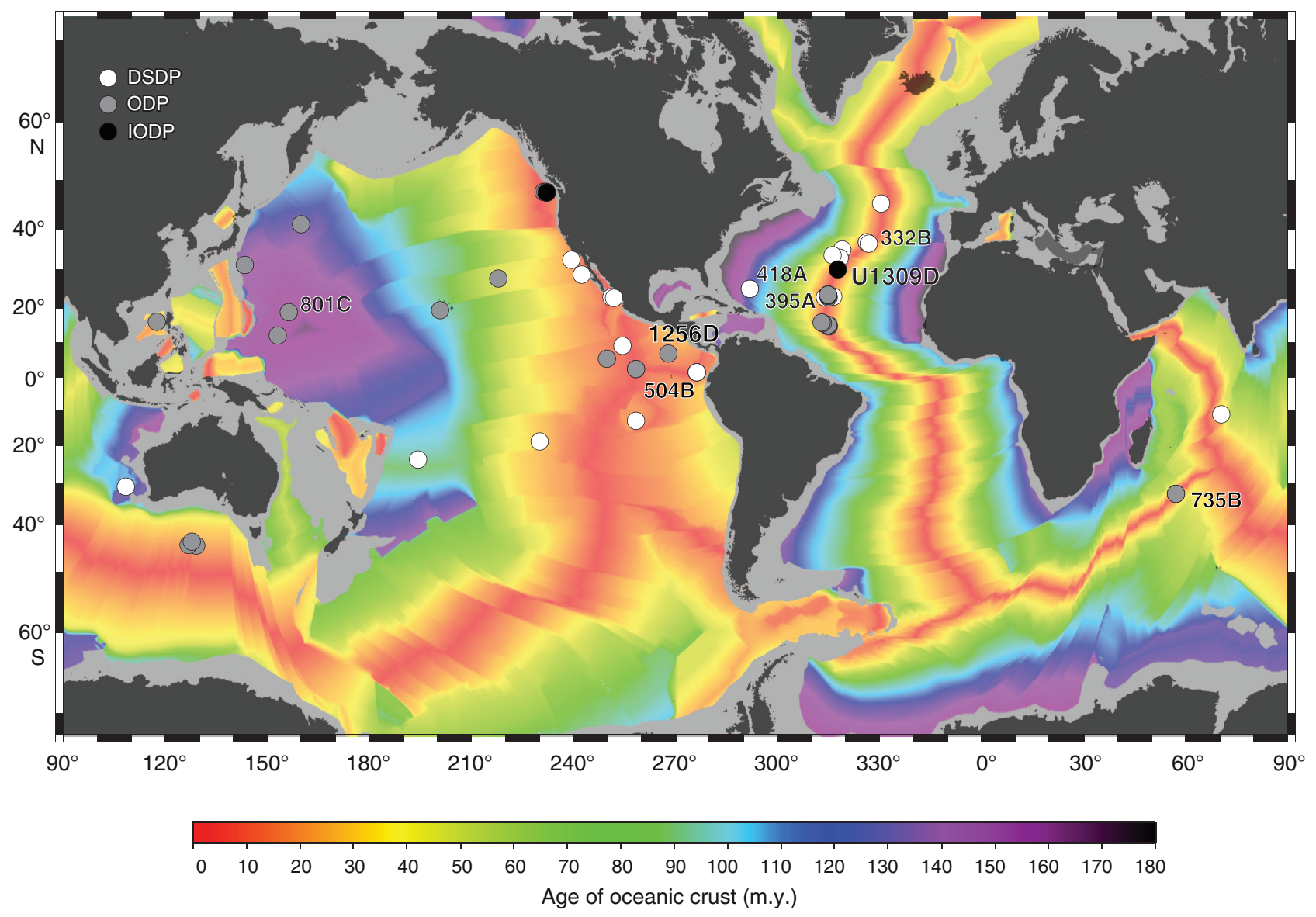


Figure F6. Compilation chart showing holes drilled $>100 \mathrm{~m}$ in intact crust and tectonically exposed lower crust and upper mantle from 1974 to 2010 (drill hole locations in Fig. F5). For each hole are indicated the hole number and the recovery (in percent) for each lithology. This compilation does not include "hard rock" drill holes in oceanic plateaus, arc basement, hydrothermal mounds, or passive margins.

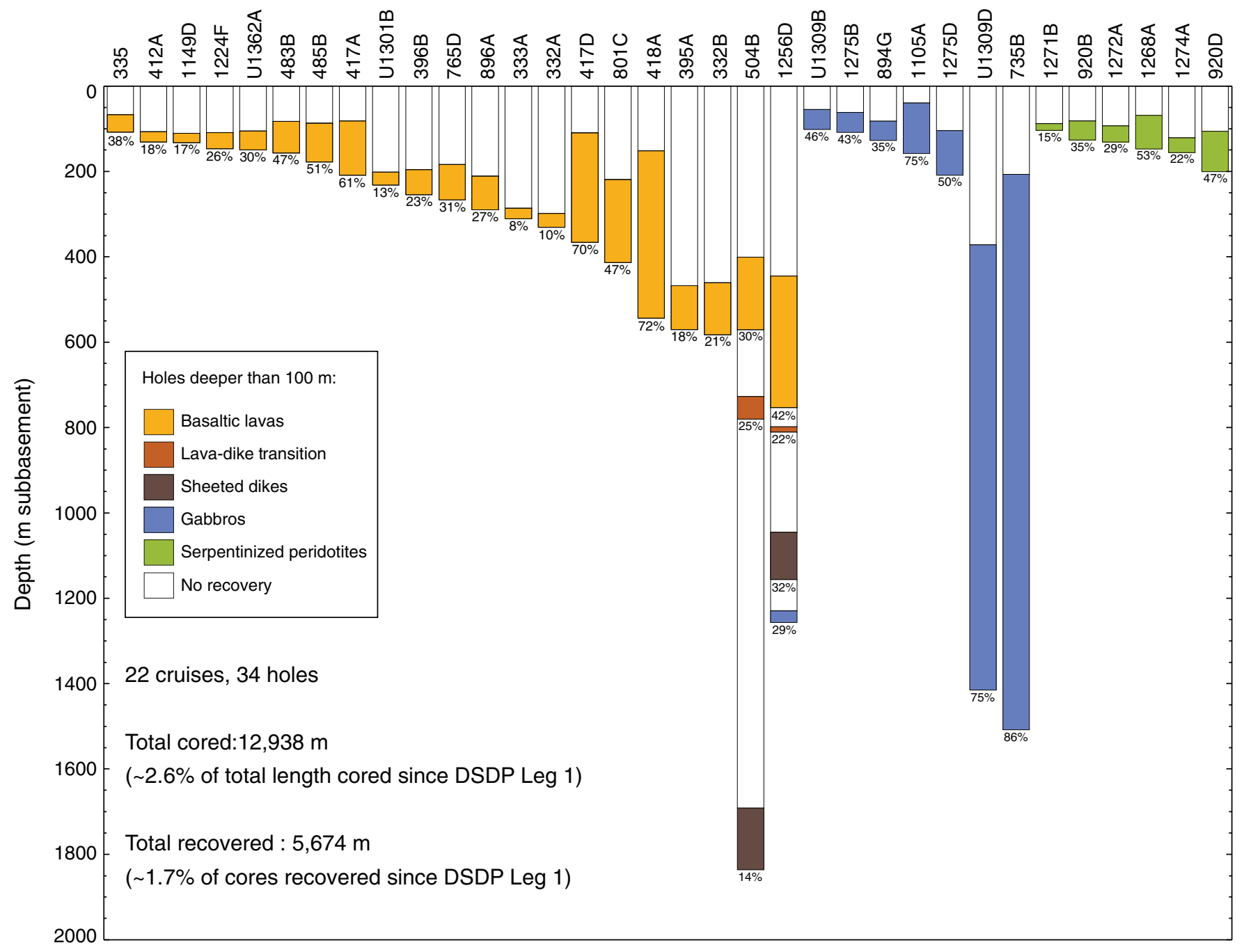


Figure F7. Age map of the Cocos plate and corresponding regions of the Pacific and Nazca plates. Isochrons at 5 m.y. intervals have been converted from magnetic anomaly identifications according to the timescale of Cande and Kent (1995). Selected DSDP and ODP sites that reached basement are indicated by circles. The wide spacing of the 10 to $20 \mathrm{Ma}$ isochrons to the south reflects the extremely fast (200-220 mm/y) full spreading rate. $\mathrm{FZ}$ = fracture zone.

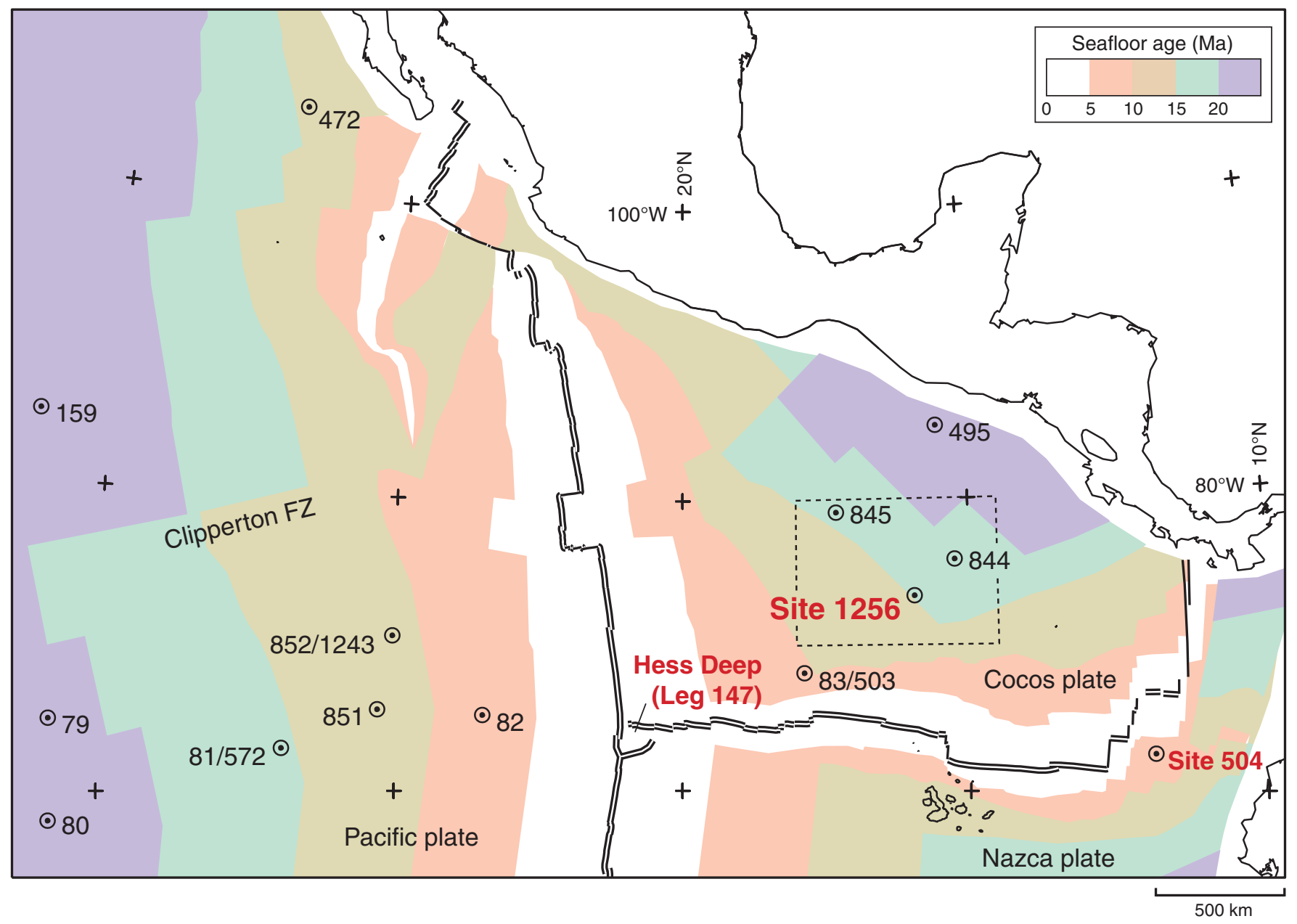


Figure F8. Time vs. depth plot for Hole 504B. Width of colored bars is proportional to the duration of DSDP and ODP legs. Major hardware failure and remediation events are reported at the depth to which they occurred. Pie charts indicate, at the end of each cruise, cumulative proportions of time spent in casing, logging, coring, and tool breaking/hole remediation since the start of operations in Hole 504B. BHA = bottom-hole assembly, FMS = Formation MicroScanner.

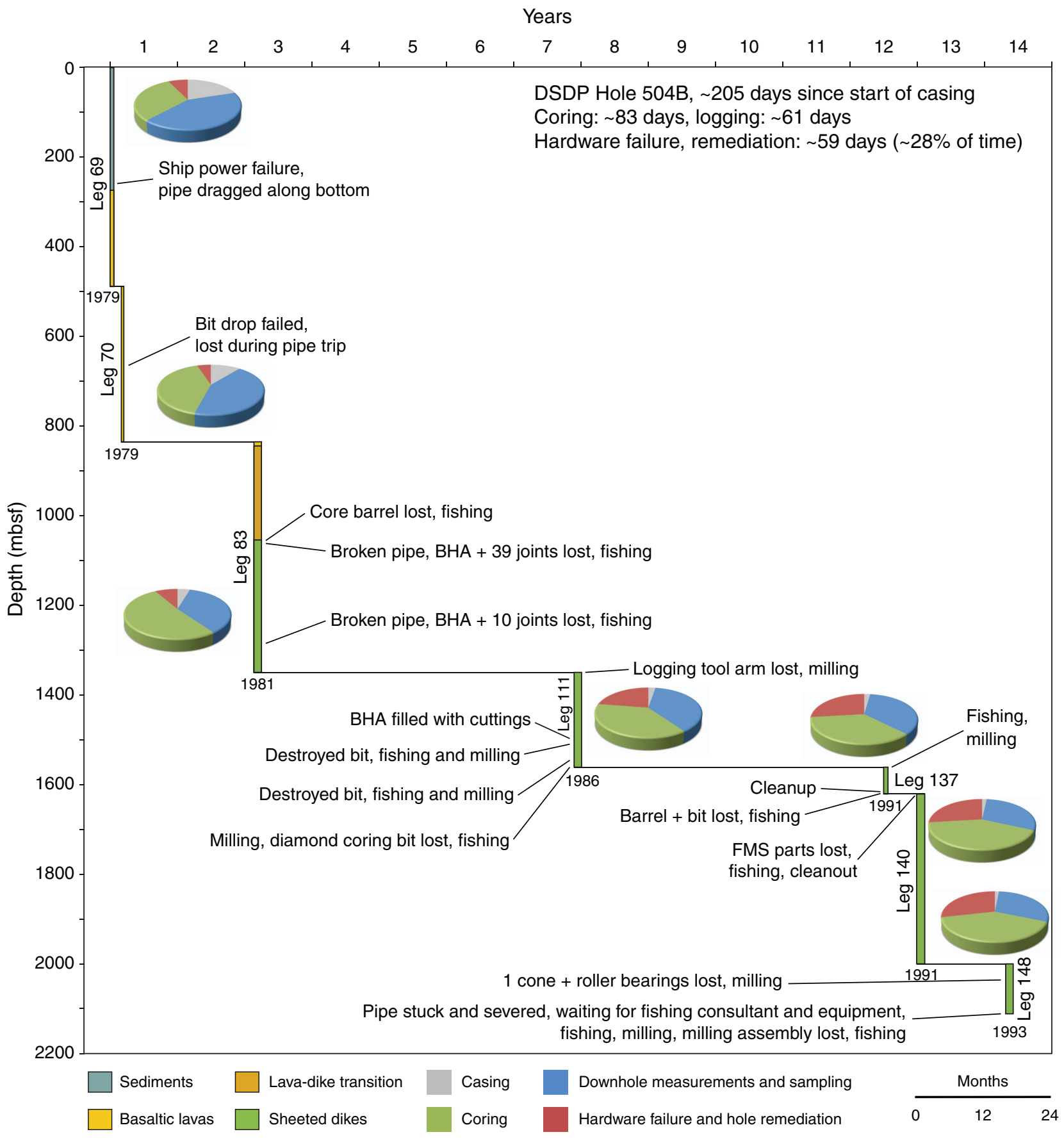


Figure F9. Time vs. depth plot for Hole 1256D. Width of colored bars is proportional to the duration of ODP legs and IODP expeditions. Major hardware failure and remediation events are reported at the depth to which they occurred. Pie charts indicate, at the end of each cruise, cumulative proportions of time spent in casing, logging, coring, and tool breaking/hole remediation and stabilization since the start of operations in Hole 1256D. BHA = bottom-hole assembly, FMS = Formation MicroScanner.

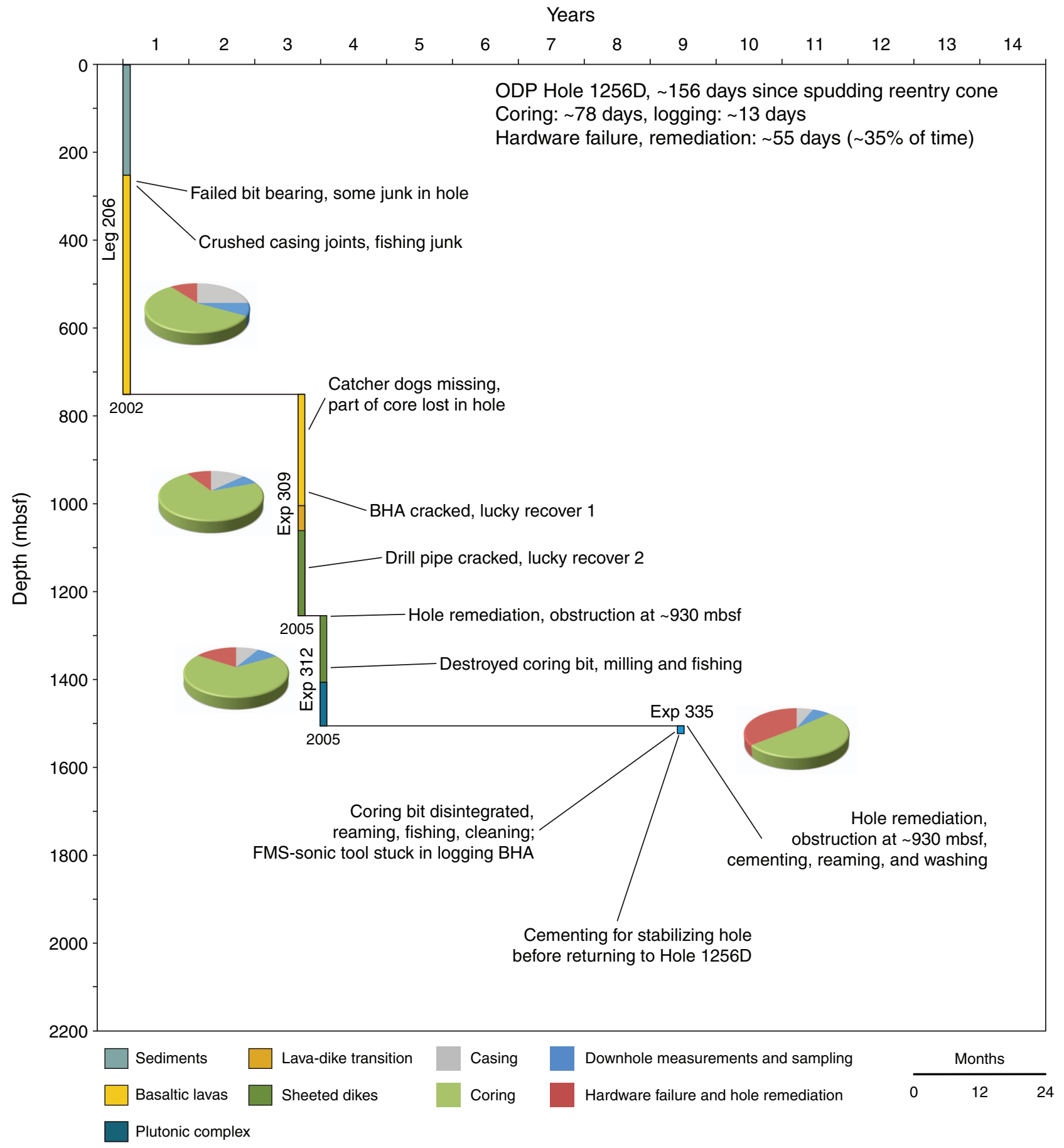


Figure F10. Plot showing the progressive deepening of Holes 504B and 1256D over eight and four scientific ocean drilling expeditions, respectively. Colored bars show the subdivision of time on site into casing, coring, downhole logging, and hole remediation activities.

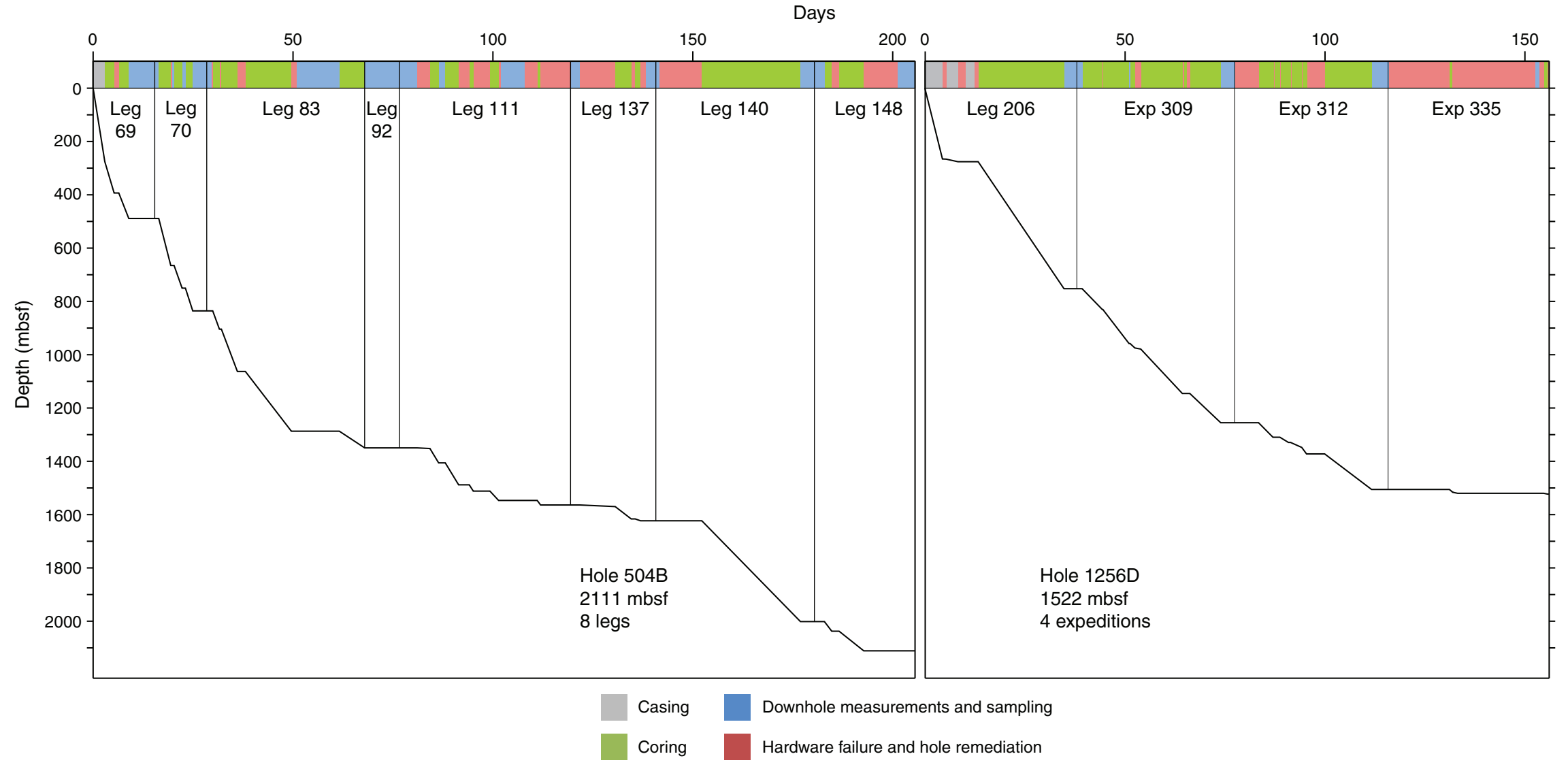




\begin{tabular}{|c|c|c|c|c|c|c|c|c|c|c|c|c|}
\hline Leg/Expedition & Hole & Latitude & Longitude & Ocean & $\begin{array}{l}\text { Water } \\
\text { depth } \\
(\mathrm{m})\end{array}$ & $\begin{array}{l}\text { Age } \\
\text { (Ma) }\end{array}$ & $\begin{array}{l}\text { Sediment } \\
\text { thickness } \\
(\mathrm{m})\end{array}$ & $\begin{array}{l}\text { Basement } \\
\text { penetration } \\
(\mathrm{m})\end{array}$ & $\begin{array}{l}\text { Recovery } \\
\text { (\%) }\end{array}$ & $\begin{array}{l}\text { Spreading } \\
\text { rate } \\
\text { (S/I/F 40/80) }\end{array}$ & Comments & Lithology \\
\hline 24 & 238 & $11^{\circ} 09.21^{\prime} \mathrm{S}$ & $70^{\circ} 31.56^{\prime} \mathrm{E}$ & Indian & 2844.5 & 30 & 506 & 81 & 50 & $S / I$ & $\begin{array}{l}\text { Projection of Chagos-Laccadive } \\
\text { Plateau }\end{array}$ & Basaltic lavas \\
\hline 26 & 257 & $30^{\circ} 59.16^{\prime} \mathrm{S}$ & $108^{\circ} 20.99^{\prime} \mathrm{E}$ & Indian & 5278 & 120 & 262 & 65 & 50 & $S / I$ & $\begin{array}{l}\text { Wharton Basin off Perth, } \\
\text { Australia }\end{array}$ & Basalt and breccia \\
\hline 34 & $319 A$ & $13^{\circ} 01.04^{\prime} \mathrm{S}$ & $101^{\circ} 31.46^{\prime} \mathrm{W}$ & Pacific & 4296 & 16 & 98 & 59 & 25 & $\mathrm{~F}$ & $\begin{array}{l}\text { Bauer Deep, } 13^{\circ} \mathrm{S} \text { East Pacific } \\
\text { Rise }\end{array}$ & Basaltic lavas \\
\hline 37 & $332 \mathrm{~A}$ & $36^{\circ} 52.72^{\prime} \mathrm{N}$ & $33^{\circ} 38.46^{\prime} \mathrm{W}$ & Atlantic & 1851 & 3.5 & 104 & 331 & 10 & S & Mid-Atlantic Ridge $36^{\circ}-37^{\circ} \mathrm{N}$ & $\begin{array}{l}\text { Basalt, basalt breccia, and } \\
\text { interlayered sediments }\end{array}$ \\
\hline 37 & $332 \mathrm{~B}$ & $36^{\circ} 52.72^{\prime} \mathrm{N}$ & $33^{\circ} 38.46^{\prime} \mathrm{W}$ & Atlantic & 1983 & 3.5 & 149 & 583 & 21 & s & Mid-Atlantic Ridge $36^{\circ}-37^{\circ} \mathrm{N}$ & Basalt and basalt breccia \\
\hline 37 & $333 \mathrm{~A}$ & $36^{\circ} 50.45^{\prime} \mathrm{N}$ & $33^{\circ} 40.05^{\prime} \mathrm{W}$ & Atlantic & 1665.8 & 3.5 & 218 & 311 & 8 & s & Mid-Atlantic Ridge $36^{\circ}-37^{\circ} \mathrm{N}$ & Basalt and basalt breccia \\
\hline 37 & 335 & $37^{\circ} 17.74^{\prime} \mathrm{N}$ & $35^{\circ} 11.92^{\prime} \mathrm{W}$ & Atlantic & 3188 & 15 & 454 & 108 & 38 & s & Mid-Atlantic Ridge $36^{\circ}-37^{\circ} \mathrm{N}$ & Basaltic lavas \\
\hline 45 & $395 \mathrm{~A}$ & $22^{\circ} 45.35^{\prime} \mathrm{N}$ & $46^{\circ} 04.90^{\prime} \mathrm{W}$ & Atlantic & 4485 & 7.3 & 92 & 571 & 18 & s & Mid-Atlantic Ridge $23^{\circ} \mathrm{N}$ & Basaltic lavas and breccia \\
\hline 45 & 396 & $22^{\circ} 58.88^{\prime} \mathrm{N}$ & $43^{\circ} 30.95^{\prime} \mathrm{W}$ & Atlantic & 4450 & 9 & 126 & 96 & 33 & s & Mid-Atlantic Ridge $23^{\circ} \mathrm{N}$ & Basaltic lavas \\
\hline 46 & 396B & $22^{\circ} 59.14^{\prime} \mathrm{N}$ & $43^{\circ} 30.90^{\prime} \mathrm{W}$ & Atlantic & 4459 & 13 & 151 & 255 & 23 & $\mathrm{~s}$ & Mid-Atlantic Ridge $23^{\circ} \mathrm{N}$ & Basalt and breccia \\
\hline 49 & $410 \mathrm{~A}$ & $45^{\circ} 30.53^{\prime} \mathrm{N}$ & $29^{\circ} 28.56^{\prime} \mathrm{W}$ & Atlantic & 2987 & 9 & 331 & 49 & 38 & s & Mid-Atlantic Ridge $45^{\circ} \mathrm{N}$ & Basaltic lavas \\
\hline 49 & $412 \mathrm{~A}$ & $36^{\circ} 33.74^{\prime} \mathrm{N}$ & $33^{\circ} 09.96^{\prime} \mathrm{W}$ & Atlantic & 2626 & 1.6 & 163 & 131 & 18 & S & Mid-Atlantic Ridge $33^{\circ} \mathrm{N}$ & $\begin{array}{l}\text { Basalt flows and intercalating } \\
\text { limestone }\end{array}$ \\
\hline $51-53$ & $417 \mathrm{~A}$ & $25^{\circ} 06.63^{\prime} \mathrm{N}$ & $68^{\circ} 02.48^{\prime} \mathrm{W}$ & Atlantic & 5478.2 & 110 & 208 & 209 & 61 & s & Western Atlantic & Basaltic lavas \\
\hline $51-53$ & 417D & $25^{\circ} 06.69^{\prime} \mathrm{N}$ & $68^{\circ} 02.81^{\prime} \mathrm{W}$ & Atlantic & 5489 & 110 & 343 & 366 & 70 & s & Western Atlantic & Basaltic lavas \\
\hline $51-53$ & $418 \mathrm{~A}$ & $25^{\circ} 02.10^{\prime} \mathrm{N}$ & $68^{\circ} 03.44^{\prime} \mathrm{W}$ & Atlantic & 5519 & 110 & 324 & 544 & 72 & $\mathrm{~s}$ & Western Atlantic & Basaltic lavas \\
\hline 54 & $428 \mathrm{~A}$ & $09^{\circ} 02.77^{\prime} \mathrm{N}$ & $105^{\circ} 26.14^{\prime} \mathrm{W}$ & Pacific & 3358.5 & 2.3 & 63 & 53 & 39 & $\mathrm{~F}$ & $9^{\circ} \mathrm{N}$ East Pacific Rise & Basaltic lavas \\
\hline 63 & 469 & $32^{\circ} 37.00^{\prime} \mathrm{N}$ & $120^{\circ} 32.90^{\prime} \mathrm{W}$ & Pacific & 3802.5 & 17 & 391 & 63 & 34 & I & Off California coast & Basaltic lavas \\
\hline 63 & $470 \mathrm{~A}$ & $28^{\circ} 54.46^{\prime} \mathrm{N}$ & $117^{\circ} 31.11^{\prime} \mathrm{W}$ & Pacific & 3554.5 & 15 & 167 & 49 & 33 & I & Off California coast & Basaltic lavas \\
\hline 65 & $482 B$ & $22^{\circ} 47.38^{\prime} \mathrm{N}$ & $107^{\circ} 59.60^{\prime} \mathrm{W}$ & Pacific & 3015 & 0.5 & 137 & 93 & 54 & 1 & Off Gulf of California & $\begin{array}{l}\text { Massive basalt and interlayered } \\
\text { sediment }\end{array}$ \\
\hline 65 & $482 \mathrm{D}$ & $22^{\circ} 47.31^{\prime} \mathrm{N}$ & $107^{\circ} 59.51^{\prime} \mathrm{W}$ & Pacific & 3015 & 0.5 & 138 & 50 & 50 & 1 & Off Gulf of California & $\begin{array}{l}\text { Massive basalt and interlayered } \\
\text { sediment }\end{array}$ \\
\hline 65 & 483 & $22^{\circ} 53.00^{\prime} \mathrm{N}$ & $108^{\circ} 44.90^{\prime} \mathrm{W}$ & Pacific & 3084 & 2 & 110 & 95 & 40 & 1 & Off Gulf of California & $\begin{array}{l}\text { Massive basalt and pillow basalt } \\
\text { with interlayered sediments }\end{array}$ \\
\hline 65 & $483 B$ & $22^{\circ} 52.99^{\prime} \mathrm{N}$ & $108^{\circ} 44.84^{\prime} \mathrm{W}$ & Pacific & 3084 & 2 & 110 & 157 & 47 & 1 & Off Gulf of California & $\begin{array}{l}\text { Massive basalt and pillow basalt } \\
\text { with interlayered sediments }\end{array}$ \\
\hline 65 & $485 \mathrm{~A}$ & $22^{\circ} 44.92^{\prime} \mathrm{N}$ & $107^{\circ} 54.23^{\prime} \mathrm{W}$ & Pacific & 2996.5 & 1.2 & 153.5 & 178 & 51 & 1 & Off Gulf of California & $\begin{array}{l}\text { Massive basalt and interlayered } \\
\text { sediments }\end{array}$ \\
\hline 68 & 501 & $1^{\circ} 13.63^{\prime} \mathrm{N}$ & $83^{\circ} 44.06^{\prime} \mathrm{W}$ & Pacific & 3466.9 & 6.6 & 264 & 73 & 60 & 1 & South flank of Costa Rica Rift & Basaltic lavas \\
\hline $\begin{array}{r}69 / 70 / 83 / 111 / \\
137 / 140 / 148\end{array}$ & $504 \mathrm{~B}$ & $1^{\circ} 13.611^{\prime} \mathrm{N}$ & $83^{\circ} 43.818^{\prime} \mathrm{W}$ & Pacific & 3474 & 6.6 & 270 & 1841 & 20 & I & South flank of Costa Rica Rift & Basalt, stockwork, and diabase \\
\hline 82 & 559 & $35^{\circ} 07.45^{\prime} \mathrm{N}$ & $40^{\circ} 55.00^{\prime} \mathrm{W}$ & Atlantic & 3754 & 35 & 238 & 63 & 37 & S & $\begin{array}{l}\text { West flank of Mid Atlantic Ridge } \\
35^{\circ} \mathrm{N}\end{array}$ & Basaltic lavas \\
\hline 82 & 562 & $33^{\circ} 08.49^{\prime} \mathrm{N}$ & $41^{\circ} 40.76^{\prime} \mathrm{W}$ & Atlantic & 3172 & 12 & 240 & 90 & 45 & S & $\begin{array}{l}\text { West flank of Mid Atlantic Ridge } \\
33^{\circ} \mathrm{N}\end{array}$ & Pillow basalt and massive basalt \\
\hline 82 & 564 & $33^{\circ} 44.36^{\prime} \mathrm{N}$ & $43^{\circ} 46.03^{\prime} \mathrm{W}$ & Atlantic & 3820 & 35 & 284 & 81 & 43 & S & $\begin{array}{l}\text { West flank of Mid Atlantic Ridge } \\
34^{\circ} \mathrm{N}\end{array}$ & $\begin{array}{l}\text { Pillow basalt and minor massive } \\
\text { basalt }\end{array}$ \\
\hline 91 & $595 B$ & $23^{\circ} 49.34^{\prime} \mathrm{S}$ & $165^{\circ} 31.61^{\prime} \mathrm{W}$ & Pacific & 5615 & 80 & 70 & 54 & 28 & $\mathrm{~F}$ & Central South Pacific & Vesicular aphyric basalt \\
\hline 92 & $597 C$ & $18^{\circ} 48.43^{\prime} \mathrm{S}$ & $129^{\circ} 46.22^{\prime} \mathrm{W}$ & Pacific & 4164 & 30 & 53 & 91 & 53 & $\mathrm{~F}$ & $\begin{array}{l}\text { West flank South East Pacific Rise } \\
18^{\circ} \mathrm{S}\end{array}$ & Massive basalt flows \\
\hline 106/109 & $648 \mathrm{~B}$ & $22^{\circ} 55.32^{\prime} \mathrm{N}$ & $44^{\circ} 56.825^{\prime} \mathrm{W}$ & Atlantic & 3326 & 0 & 0 & 50 & 12 & $\mathrm{~s}$ & Mid-Atlantic Ridge $23^{\circ} \mathrm{N}$ & Pillow basalt \\
\hline 109 & $670 \mathrm{~A}$ & $23^{\circ} 9.996^{\prime} \mathrm{N}$ & $45^{\circ} 1.932^{\prime} \mathrm{W}$ & Atlantic & 3625 & 0 & 0 & 77 & 6 & s & Mid-Atlantic Ridge, MARK, $23^{\circ} \mathrm{N}$ & Serpentinized peridotite \\
\hline $118 / 176$ & $735 \mathrm{~B}$ & $32^{\circ} 43.395^{\prime} \mathrm{S}$ & $57^{\circ} 15.959^{\prime} \mathrm{E}$ & Indian & 720 & 11.8 & 0 & 1508 & 86 & S & $\begin{array}{l}\text { Atlantis Bank, Southwest Indian } \\
\text { Ridge }\end{array}$ & Gabbro \\
\hline 123 & $765 \mathrm{D}$ & $15^{\circ} 58.56^{\prime} \mathrm{S}$ & $117^{\circ} 34.51^{\prime} \mathrm{E}$ & Indian & 5713.8 & 140 & 928 & 267 & 31 & $\mathrm{~F}$ & Argo Abyssal Plain & $\begin{array}{l}\text { North-east mid-ocean-ridge } \\
\text { basaltic lavas }\end{array}$ \\
\hline
\end{tabular}


Table T1 (continued). (Continued on next page).

\begin{tabular}{|c|c|c|c|c|c|c|c|c|c|c|c|c|}
\hline Leg/Expedition & Hole & Latitude & Longitude & Ocean & $\begin{array}{l}\text { Water } \\
\text { depth } \\
(\mathrm{m})\end{array}$ & $\begin{array}{l}\text { Age } \\
(\mathrm{Ma})\end{array}$ & $\begin{array}{l}\text { Sediment } \\
\text { thickness } \\
(\mathrm{m})\end{array}$ & $\begin{array}{l}\text { Basement } \\
\text { penetration } \\
(\mathrm{m})\end{array}$ & $\begin{array}{l}\text { Recovery } \\
\text { (\%) }\end{array}$ & $\begin{array}{c}\text { Spreading } \\
\text { rate } \\
\text { (S/I/F 40/80) }\end{array}$ & Comments & Lithology \\
\hline $129 / 185$ & $801 C$ & $18^{\circ} 38.538^{\prime} \mathrm{N}$ & $156^{\circ} 21.59^{\prime} \mathrm{E}$ & Pacific & 5674 & 170 & 462 & 414 & 47 & $\mathrm{~F}$ & Western North Pacific & $\begin{array}{l}\text { Pillow basalt, basalt flows, and } \\
\text { breccias }\end{array}$ \\
\hline 129 & $802 \mathrm{~A}$ & $12^{\circ} 5.778^{\prime} \mathrm{N}$ & $153^{\circ} 12.63^{\prime} \mathrm{E}$ & Pacific & 5980 & 120 & 509 & 51 & 33 & $\mathrm{~F}$ & Western North Pacific & Basaltic lavas \\
\hline 136 & $843 B$ & $19^{\circ} 20.54^{\prime} \mathrm{N}$ & $159^{\circ} 5.68^{\prime} \mathrm{W}$ & Pacific & 4418 & 95 & 243 & 71 & 37 & $\mathrm{~F}$ & West of Hawaii & Basaltic lavas \\
\hline 147 & $894 \mathrm{E}$ & $2^{\circ} 18.059^{\prime} \mathrm{N}$ & $101^{\circ} 31.524^{\prime} \mathrm{W}$ & Pacific & 3014 & 1 & 0 & 29 & 11 & $\mathrm{~F}$ & Hess Deep & Gabbro \\
\hline 147 & $894 \mathrm{~F}$ & $2^{\circ} 17.976^{\prime} \mathrm{N}$ & $101^{\circ} 31.554^{\prime} \mathrm{W}$ & Pacific & 3025 & 1 & 0 & 26 & 7 & $\mathrm{~F}$ & Hess Deep & Gabbro \\
\hline 147 & $894 \mathrm{G}$ & $2^{\circ} 17.976^{\prime} \mathrm{N}$ & $101^{\circ} 31.554^{\prime} \mathrm{W}$ & Pacific & 3023 & 1 & 0 & 127.5 & 35 & $\mathrm{~F}$ & Hess Deep & Gabbro \\
\hline 147 & $895 \mathrm{~A}$ & $2^{\circ} 16.638^{\prime} \mathrm{N}$ & $101^{\circ} 26.766^{\prime} \mathrm{W}$ & Pacific & 3821 & 1 & 0 & 17 & 14 & $\mathrm{~F}$ & Hess Deep & Serpentinized peridotite \\
\hline 147 & $895 B$ & $2^{\circ} 16.638^{\prime} \mathrm{N}$ & $101^{\circ} 26.760^{\prime} \mathrm{W}$ & Pacific & 3821 & 1 & 0 & 10 & 10 & $\mathrm{~F}$ & Hess Deep & Serpentinized peridotite \\
\hline 147 & $895 C$ & $2^{\circ} 16.632^{\prime} \mathrm{N}$ & $101^{\circ} 26.772^{\prime} \mathrm{W}$ & Pacific & 3820 & 1 & 0 & 38 & 15 & $\mathrm{~F}$ & Hess Deep & Serpentinized peridotite \\
\hline 147 & 895D & $2^{\circ} 16.638^{\prime} \mathrm{N}$ & $101^{\circ} 26.778^{\prime} \mathrm{W}$ & Pacific & 3821 & 1 & 0 & 94 & 20 & $\mathrm{~F}$ & Hess Deep & Serpentinized peridotite \\
\hline 147 & $895 \mathrm{E}$ & $2^{\circ} 16.788^{\prime} \mathrm{N}$ & $101^{\circ} 26.790^{\prime} \mathrm{W}$ & Pacific & 3753 & 1 & 0 & 88 & 37 & $\mathrm{~F}$ & Hess Deep & Serpentinized peridotite \\
\hline 147 & $895 \mathrm{~F}$ & $2^{\circ} 16.902^{\prime} \mathrm{N}$ & $101^{\circ} 26.790^{\prime} \mathrm{W}$ & Pacific & 3693 & 1 & 0 & 26 & 8 & $\mathrm{~F}$ & Hess Deep & Serpentinized peridotite \\
\hline 148 & $896 \mathrm{~A}$ & $1^{\circ} 13.006^{\prime} \mathrm{N}$ & $83^{\circ} 43.392^{\prime} \mathrm{W}$ & Pacific & 3459 & 6.6 & 179 & 290 & 27 & 1 & South flank of Costa Rica Rift & Basaltic lavas \\
\hline 153 & $920 \mathrm{~B}$ & $23^{\circ} 20.310^{\prime} \mathrm{N}$ & $45^{\circ} 1.038^{\prime} \mathrm{W}$ & Atlantic & 3339 & $<1$ & 0 & 126.4 & 35.3 & $\mathrm{~s}$ & Mid-Atlantic Ridge, MARK, $23^{\circ} \mathrm{N}$ & Serpentinized peridotite \\
\hline 153 & 920D & $23^{\circ} 20.322^{\prime} \mathrm{N}$ & $45^{\circ} 1.044^{\prime} \mathrm{W}$ & Atlantic & 3338 & $<1$ & 0 & 200.8 & 47.3 & $\mathrm{~s}$ & Mid-Atlantic Ridge, MARK, $23^{\circ} \mathrm{N}$ & Serpentinized peridotite \\
\hline 153 & $921 \mathrm{~A}$ & $23^{\circ} 32.460^{\prime} \mathrm{N}$ & $45^{\circ} 1.866^{\prime} \mathrm{W}$ & Atlantic & 2488 & $<1$ & 0 & 17.1 & 18.1 & $\mathrm{~s}$ & Mid-Atlantic Ridge, MARK, $23^{\circ} \mathrm{N}$ & Gabbro \\
\hline 153 & $921 \mathrm{~B}$ & $23^{\circ} 32.478^{\prime} \mathrm{N}$ & $45^{\circ} 1.842^{\prime} \mathrm{W}$ & Atlantic & 2490 & $<1$ & 0 & 44.1 & 19.4 & $\mathrm{~s}$ & Mid-Atlantic Ridge, MARK, $23^{\circ} \mathrm{N}$ & Gabbro \\
\hline 153 & $921 \mathrm{C}$ & $23^{\circ} 32.472^{\prime} \mathrm{N}$ & $45^{\circ} 1.830^{\prime} \mathrm{W}$ & Atlantic & 2495 & $<1$ & 0 & 53.4 & 11.4 & $\mathrm{~s}$ & Mid-Atlantic Ridge, MARK, $23^{\circ} \mathrm{N}$ & Gabbro \\
\hline 153 & 921D & $23^{\circ} 32.442^{\prime} \mathrm{N}$ & $45^{\circ} 1.830^{\prime} \mathrm{W}$ & Atlantic & 2514 & $<1$ & 0 & 48.6 & 12.7 & $\mathrm{~s}$ & Mid-Atlantic Ridge, MARK, $23^{\circ} \mathrm{N}$ & Gabbro \\
\hline 153 & $921 \mathrm{E}$ & $23^{\circ} 32.328^{\prime} \mathrm{N}$ & $45^{\circ} 1.878^{\prime} \mathrm{W}$ & Atlantic & 2456 & $<1$ & 0 & 82.6 & 21.4 & $\mathrm{~s}$ & Mid-Atlantic Ridge, MARK, $23^{\circ} \mathrm{N}$ & Gabbro \\
\hline 153 & $922 \mathrm{~A}$ & $23^{\circ} 33.162^{\prime} \mathrm{N}$ & $45^{\circ} 1.926^{\prime} \mathrm{W}$ & Atlantic & 2612 & $<1$ & 0 & 14.6 & 63.2 & $\mathrm{~s}$ & Mid-Atlantic Ridge, MARK, $23^{\circ} \mathrm{N}$ & Gabbro \\
\hline 153 & $922 \mathrm{~B}$ & $23^{\circ} 31.368^{\prime} \mathrm{N}$ & $45^{\circ} 1.926^{\prime} \mathrm{W}$ & Atlantic & 2612 & $<1$ & 0 & 37.4 & 25.6 & $\mathrm{~s}$ & Mid-Atlantic Ridge, MARK, $23^{\circ} \mathrm{N}$ & Gabbro \\
\hline 153 & $923 \mathrm{~A}$ & $23^{\circ} 32.556^{\prime} \mathrm{N}$ & $45^{\circ} 1.896^{\prime} \mathrm{W}$ & Atlantic & 2440 & $<1$ & 0 & 70 & 57.2 & $\mathrm{~s}$ & Mid-Atlantic Ridge, MARK, $23^{\circ} \mathrm{N}$ & Gabbro \\
\hline 153 & $924 \mathrm{~B}$ & $23^{\circ} 32.460^{\prime} \mathrm{N}$ & $45^{\circ} 0.858^{\prime} \mathrm{W}$ & Atlantic & 3170 & $<1$ & 0 & 30.8 & 8.7 & $\mathrm{~s}$ & Mid-Atlantic Ridge, MARK, $23^{\circ} \mathrm{N}$ & Gabbro \\
\hline 153 & $924 \mathrm{C}$ & $23^{\circ} 32.496^{\prime} \mathrm{N}$ & $45^{\circ} 0.864^{\prime} \mathrm{W}$ & Atlantic & 3177 & $<1$ & 0 & 48.5 & 23.1 & $\mathrm{~s}$ & Mid-Atlantic Ridge, MARK, $23^{\circ} \mathrm{N}$ & Gabbro \\
\hline 168 & $1025 \mathrm{C}$ & $47^{\circ} 53.250^{\prime} \mathrm{N}$ & $128^{\circ} 38.880^{\prime} \mathrm{W}$ & Pacific & 2602 & 1.237 & 106 & 41 & 37 & I & Juan de Fuca Flank & Basalt \\
\hline 168 & $1026 \mathrm{~B}$ & $47^{\circ} 45.759^{\prime} \mathrm{N}$ & $127^{\circ} 45.552^{\prime} \mathrm{W}$ & Pacific & 2658 & 3.511 & 256 & 39 & 5 & 1 & Juan de Fuca Flank & Basalt \\
\hline 168 & $1026 \mathrm{C}$ & $47^{\circ} 46.261^{\prime} \mathrm{N}$ & $127^{\circ} 45.186^{\prime} \mathrm{W}$ & Pacific & 2669 & 3.516 & 229 & 19 & 3.5 & 1 & Juan de Fuca Flank & Basalt \\
\hline 168 & $1032 \mathrm{~A}$ & $47^{\circ} 46.776^{\prime} \mathrm{N}$ & $128^{\circ} 7.320^{\prime} \mathrm{W}$ & Pacific & 2645 & 2.621 & 290 & 48 & 6.5 & 1 & Juan de Fuca Flank & Basalt \\
\hline 179 & $1105 \mathrm{~A}$ & $32^{\circ} 43.135^{\prime} \mathrm{S}$ & $57^{\circ} 16.652^{\prime} \mathrm{E}$ & Indian & 714 & 11.8 & 0 & 158 & 75 & $S$ & $\begin{array}{l}\text { Atlantis Bank, Southwest Indian } \\
\text { Ridge }\end{array}$ & Gabbro \\
\hline 185 & $1149 D$ & $31^{\circ} 18.79^{\prime} \mathrm{N}$ & $143^{\circ} 24.03^{\prime} \mathrm{E}$ & Pacific & 5818 & 133 & 307 & 133 & 17 & $\mathrm{~F}$ & Western North Pacific & $\begin{array}{l}\text { Pillow basalt, basalt flows, and } \\
\text { breccias }\end{array}$ \\
\hline 187 & $1162 \mathrm{~B}$ & $44^{\circ} 37.9^{\prime} \mathrm{S}$ & $129^{\circ} 11.3^{\prime} \mathrm{E}$ & Indian & 5464 & 18 & 333 & 59 & 17 & 1 & Australian-Antarctic Discordance & Basaltic lavas and breccia \\
\hline 187 & $1163 \mathrm{~A}$ & $44^{\circ} 25.5^{\prime} \mathrm{S}$ & $126^{\circ} 54.5^{\prime} \mathrm{E}$ & Indian & 4354 & 17 & 161 & 47 & 33 & 1 & Australian-Antarctic Discordance & Basaltic lavas \\
\hline 187 & $1164 B$ & $43^{\circ} 45.0^{\prime} \mathrm{S}$ & $127^{\circ} 44.8^{\prime} \mathrm{E}$ & Indian & 4798 & 18.5 & 150 & 66 & 16 & 1 & Australian-Antarctic Discordance & Basaltic lavas \\
\hline 191 & 1179D & $41^{\circ} 04.8^{\prime} \mathrm{N}$ & $159^{\circ} 57.8^{\prime} \mathrm{E}$ & Pacific & 5563.9 & 129 & 377 & 98 & 44 & $\mathrm{~F}$ & Western North Pacific & Basaltic lavas \\
\hline 200 & $1224 \mathrm{~F}$ & $27^{\circ} 53.36^{\prime} \mathrm{N}$ & $141^{\circ} 58.77^{\prime} \mathrm{W}$ & Pacific & 4967.1 & 46 & 28 & 147 & 26 & $\mathrm{~F}$ & Central Pacific & Basaltic lavas \\
\hline 203 & $1243 B$ & $5^{\circ} 18.07^{\prime} \mathrm{N}$ & $110^{\circ} 04.58^{\prime} \mathrm{W}$ & Pacific & 3868 & 11 & 110 & 87 & 25 & $\mathrm{~F}$ & $\begin{array}{l}\text { Western flank East Pacific Rise } \\
5^{\circ} \mathrm{N}\end{array}$ & Basaltic lavas \\
\hline 206 & $1256 C$ & $6^{\circ} 44.18^{\prime} \mathrm{N}$ & $91^{\circ} 56.06^{\prime} \mathrm{W}$ & Pacific & 3634.7 & 15 & 251 & 89 & 61 & $\mathrm{~F}$ & $\begin{array}{l}\text { Cocos plate eastern flank East } \\
\text { Pacific Rise }\end{array}$ & Basaltic lavas \\
\hline 206/309/312 & $1256 \mathrm{D}$ & $6^{\circ} 44.16^{\prime} \mathrm{N}$ & $91^{\circ} 56.06^{\prime} \mathrm{W}$ & Pacific & 3634.7 & 15 & 250 & 1257.1 & 37.1 & $\mathrm{~F}$ & $\begin{array}{l}\text { Cocos plate eastern flank East } \\
\text { Pacific Rise }\end{array}$ & $\begin{array}{l}\text { Basaltic lavas, sheeted dike, and } \\
\text { varitextured gabbro }\end{array}$ \\
\hline 209 & $1268 \mathrm{~A}$ & $14^{\circ} 50.755^{\prime} \mathrm{N}$ & $45^{\circ} 4.641^{\prime} \mathrm{W}$ & Atlantic & 3007 & & 0 & 147.6 & 53.3 & $\mathrm{~s}$ & Mid-Atlantic Ridge $15^{\circ} 20^{\prime} \mathrm{N}$ & Serpentinized peridotite \\
\hline 209 & $1270 \mathrm{~A}$ & $14^{\circ} 43.342^{\prime} \mathrm{N}$ & $44^{\circ} 53.321^{\prime} \mathrm{W}$ & Atlantic & 1951 & & 0 & 26.9 & 12.2 & $\mathrm{~s}$ & Mid-Atlantic Ridge $15^{\circ} 20^{\prime} \mathrm{N}$ & Gabbro \\
\hline 209 & $1270 B$ & $14^{\circ} 43.265^{\prime} \mathrm{N}$ & $44^{\circ} 53.225^{\prime} \mathrm{W}$ & Atlantic & 1909 & & 0 & 45.9 & 37.4 & $\mathrm{~s}$ & Mid-Atlantic Ridge $15^{\circ} 20^{\prime} \mathrm{N}$ & Gabbro \\
\hline 209 & $1270 \mathrm{C}$ & $14^{\circ} 43.284^{\prime} \mathrm{N}$ & $44^{\circ} 53.091^{\prime} \mathrm{W}$ & Atlantic & 1822 & & 0 & 18.6 & 10.6 & $\mathrm{~s}$ & Mid-Atlantic Ridge $15^{\circ} 20^{\prime} \mathrm{N}$ & Gabbro \\
\hline 209 & 1270D & $14^{\circ} 43.270^{\prime} \mathrm{N}$ & $44^{\circ} 53.084^{\prime} \mathrm{W}$ & Atlantic & 1817 & & 0 & 57.3 & 13.4 & $\mathrm{~s}$ & Mid-Atlantic Ridge $15^{\circ} 20^{\prime} \mathrm{N}$ & Gabbro \\
\hline 209 & $1271 \mathrm{~A}$ & $15^{\circ} 2.222^{\prime} \mathrm{N}$ & $44^{\circ} 56.887^{\prime} \mathrm{W}$ & Atlantic & 3612 & & 0 & 44.8 & 12.9 & $\mathrm{~s}$ & Mid-Atlantic Ridge $15^{\circ} 20^{\prime} \mathrm{N}$ & Serpentinized peridotite \\
\hline
\end{tabular}




\begin{tabular}{|c|c|c|c|c|c|c|c|c|c|c|c|c|}
\hline Leg/Expedition & Hole & Latitude & Longitude & Ocean & $\begin{array}{l}\text { Water } \\
\text { depth } \\
(\mathrm{m})\end{array}$ & $\begin{array}{l}\text { Age } \\
(\mathrm{Ma})\end{array}$ & $\begin{array}{l}\text { Sediment } \\
\text { thickness } \\
(\mathrm{m})\end{array}$ & $\begin{array}{l}\text { Basement } \\
\text { penetration } \\
\quad(\mathrm{m})\end{array}$ & $\begin{array}{c}\text { Recovery } \\
\text { (\%) }\end{array}$ & $\begin{array}{l}\text { Spreading } \\
\text { rate } \\
\text { (S/I/F 40/80) }\end{array}$ & Comments & Lithology \\
\hline 209 & 1271B & $15^{\circ} 2.189^{\prime} \mathrm{N}$ & $44^{\circ} 56.912^{\prime} \mathrm{W}$ & Atlantic & 3585 & & 0 & 103.8 & 15.3 & $\mathrm{~s}$ & Mid-Atlantic Ridge $15^{\circ} 20^{\prime} \mathrm{N}$ & Serpentinized peridotite \\
\hline 209 & $1272 A$ & $15^{\circ} 5.666^{\prime} \mathrm{N}$ & $44^{\circ} 58.300^{\prime} \mathrm{W}$ & Atlantic & 2560 & & 0 & 131 & 28.6 & $\mathrm{~s}$ & Mid-Atlantic Ridge $15^{\circ} 20^{\prime} \mathrm{N}$ & Serpentinized peridotite \\
\hline 209 & $1274 \mathrm{~A}$ & $15^{\circ} 38.867^{\prime} \mathrm{N}$ & $46^{\circ} 40.582^{\prime} \mathrm{W}$ & Atlantic & 3940 & & 0 & 155.8 & 22.2 & $\mathrm{~s}$ & Mid-Atlantic Ridge $15^{\circ} 20^{\prime} \mathrm{N}$ & Serpentinized peridotite \\
\hline 209 & $1275 B$ & $15^{\circ} 44.486^{\prime} \mathrm{N}$ & $46^{\circ} 54.208^{\prime} \mathrm{W}$ & Atlantic & 1562 & & 0 & 108.7 & 43.1 & $\mathrm{~s}$ & Mid-Atlantic Ridge $15^{\circ} 20^{\prime} \mathrm{N}$ & Gabbro \\
\hline 209 & 1275D & $15^{\circ} 44.440^{\prime} \mathrm{N}$ & $46^{\circ} 54.217^{\prime} \mathrm{W}$ & Atlantic & 1554 & & 0 & 209 & 50 & $\mathrm{~s}$ & Mid-Atlantic Ridge $15^{\circ} 20^{\prime} \mathrm{N}$ & Gabbro \\
\hline 301 & U1301A & $47^{\circ} 45.209^{\prime} \mathrm{N}$ & $127^{\circ} 45.833^{\prime} \mathrm{W}$ & Pacific & 2656 & 3.5 & 262 & 108 & 0 & I & $\begin{array}{l}\text { Juan de Fuca Ridge flank; no } \\
\text { coring (CORK) }\end{array}$ & Basaltic lavas \\
\hline 301 & U1301B & $47^{\circ} 45.229^{\prime} \mathrm{N}$ & $127^{\circ} 45.826^{\prime} \mathrm{W}$ & Pacific & 2655 & 3.5 & 265 & 318 & 12.9 & 1 & $\begin{array}{l}\text { Juan de Fuca Ridge flank; } \\
\text { recovery is only for the } 232 \mathrm{~m} \\
\text { of cored basement }\end{array}$ & Basaltic lavas \\
\hline 304 & U1309B & $30^{\circ} 10.108^{\prime} \mathrm{N}$ & $42^{\circ} 7.110^{\prime} \mathrm{W}$ & Atlantic & 1642 & 2 & 2 & 99.8 & 45.9 & $\mathrm{~s}$ & Mid-Atlantic Ridge $30^{\circ} \mathrm{N}$ & Gabbro \\
\hline $304 / 305$ & U1309D & $30^{\circ} 10.120^{\prime} \mathrm{N}$ & $42^{\circ} 7.113^{\prime} \mathrm{W}$ & Atlantic & 1645 & 2 & 2 & 1413.3 & 74.8 & s & Mid-Atlantic Ridge $30^{\circ} \mathrm{N}$ & Gabbro \\
\hline 327 & U1362A & $47^{\circ} 45.663^{\prime} \mathrm{N}$ & $127^{\circ} 45.672^{\prime} \mathrm{W}$ & Pacific & 2661 & 3.5 & 236 & 292 & 29.6 & I & $\begin{array}{l}\text { Juan de Fuca Ridge flank; } \\
\text { recovery is only for the } 150 \mathrm{~m} \\
\text { of cored basement }\end{array}$ & Basaltic lavas \\
\hline
\end{tabular}

Compilation does not include other "hard rock" drill holes in oceanic plateaus, arc basement, hydrothermal mounds, or passive margins. $S=$ slow, I = intermediate, $F=$ fast. MARK = Mid-Atlantic Ridge Kane Fracture Zone. CORK = circulation obviation retrofit kit. This table is available in ASCII and in Microsoft Excel format (see 104_T1.XLS in CHAPTER_104 in TABLES in "Supplementary material"). 
Table T2. Preferred conditions for the siting of multiple-expedition deep drill holes for successful drilling and scheduling.

\begin{tabular}{|c|c|c|}
\hline Criteria & Preferred conditions & Site 1256 \\
\hline \multicolumn{3}{|l|}{ Geographic parameters: } \\
\hline Transit from major ports & $<5$ days: maximizes time on site and allows emergency resupply & $\begin{array}{l}2 \text { to } 3.5 \text { days from Mexican and Central } \\
\text { American ports }\end{array}$ \\
\hline Proximity to oft-transited regions & Preferred: ensures site is rarely far removed from region of operations & 3.5 days from Pacific end of Panama Canal \\
\hline Weather window & 12 months & 12 months \\
\hline \multicolumn{3}{|l|}{ Geological parameters: } \\
\hline Installation of reentry cone and casing & Sediment overburden of $\sim 100 \mathrm{~m}$ or more & $\sim 250 \mathrm{~m}$ \\
\hline Seismic velocity & Higher $V_{\mathrm{p}}$ likely to indicate less fracture formations & Targeted region of relatively high $V_{p}$ \\
\hline Thermal state & Lower temperatures at depth with age $(>20 \mathrm{Ma}),<200^{\circ} \mathrm{C}$ at target depth & $\begin{array}{l}15 \mathrm{Ma} \\
\sim 125^{\circ} \mathrm{C} \text { at } 2000 \mathrm{mbsf} \\
\sim 300^{\circ} \mathrm{C} \text { at Moho }\end{array}$ \\
\hline Potential for riser drilling & $<4000$ m water depth & $3635 \mathrm{~m}$ water depth \\
\hline Age of ocean crust & $<30 \mathrm{Ma}$ to investigate modern Earth system & $15 \mathrm{Ma}$ \\
\hline Magnetic measurements & $\begin{array}{l}\text { Original location } \pm \text { more than } 20^{\circ} \text { of Equator for magnetic polarity } \\
\text { determination from azimuthally unoriented core. } \\
\text { Avoid north-south oriented ridge segments as inclination insensitive to } \\
\text { tilting }\end{array}$ & $\begin{array}{l}\text { Formed } 1^{\circ} \mathrm{N} \text { on approximately north-south } \\
\text { ridge segment }\end{array}$ \\
\hline
\end{tabular}

For more information on seismic velocity, see Figure F23 in the "Expedition 335 summary" chapter (Expedition 335 Scientists, 2012 ). Green = Site 1256 meets preferred conditions, red = Site 1256 does not meet preferred conditions. 
Table T3. Summary of operations at Hole 504B (DSDP Legs 69, 70, 83 and 92; ODP Legs 111, 137, 140 and 148). (Continued on next four pages.)

\begin{tabular}{|c|c|c|c|c|c|c|}
\hline Leg & Date & $\begin{array}{c}\text { Time } \\
(h)\end{array}$ & $\begin{array}{l}\text { Depth } \\
\text { (mbsf) }\end{array}$ & Comment & Brief run description & $\begin{array}{c}\text { Time } \\
\text { (days) }\end{array}$ \\
\hline $\begin{array}{l}69 \\
69\end{array}$ & $\begin{array}{l}8 \text { Oct } 1979 \\
10 \text { Oct } 1979\end{array}$ & $\begin{array}{l}2145 \\
1330\end{array}$ & $\begin{array}{l}260.5 \\
275\end{array}$ & $\begin{array}{l}\text { Start coring from } 260.5 \text { mbsf (Cores } 1 \text { and } 2 \text { in sediments). } \\
\text { Start casing to } 275 \mathrm{mbsf} \text {. }\end{array}$ & $\begin{array}{l}\text { Reentry } 1 \text { for casing (after washing + coring } \\
\text { sediments) }\end{array}$ & 3.09 \\
\hline 69 & 12 Oct 1979 & 0000 & 275 & Start coring in basement, bit Run 1, Core 3. & Reentry 2, coring bit Run 1, Cores 3-16 & 2.27 \\
\hline 69 & 14 Oct 1979 & 0630 & 393 & End coring bit Run 1, Core 16. & & \\
\hline 69 & 14 Oct 1979 & & & Operations in Hole $504 \mathrm{C}$ for half a day. & & \\
\hline 69 & 15 Oct 1979 & 2000 & 393 & $\begin{array}{l}\text { Ship power failure and drift northward; drill string dragged along soft sediments. Inspection of } \\
\text { drill pipe and magnaflux most vulnerable sections. }\end{array}$ & & 1.10 \\
\hline 69 & 16 Oct 1979 & 2230 & 393 & Start coring bit Run 2, Core 17. & Reentry 3, coring bit Run 2, Cores $17-29$ & 2.54 \\
\hline 69 & 19 Oct 1979 & 1130 & 489 & End coring bit Run 2, Core 29. & & \\
\hline 69 & 20 Oct 1979 & 2020 & 489 & Downhole experiments and logging. NB: Pipe stuck after packer sampling. & Reentry 4, downhole measurements & 6.45 \\
\hline 69 & 25 Oct 1979 & 2225 & 489 & End of downhole experiments and logging. & & \\
\hline 69 & & & & & Total: & 15.47 \\
\hline 70 & 3 Dec 1979 & 1343 & 489 & Reentry in hole, $<2$ months after previous operations. & & \\
\hline 70 & 3 Dec 1979 & 1343 & 489 & Temperature measurement. & Reentry 5, downhole measurements & 1.01 \\
\hline 70 & 4 Dec 1979 & 1400 & 489 & Start coring bit Run 3, Core 30. & Reentry 6 , coring bit Run 3 , Cores $30-49$ & 2.98 \\
\hline 70 & 7 Dec 1979 & 1331 & 665 & End coring bit Run 3, Core 49. & & \\
\hline 70 & 7 Dec 1979 & 2130 & 665 & Bit drop on seafloor unsuccessful, hence no logging; bit lost during pipe trip. & Bit lost on seafloor & 0.33 \\
\hline 70 & 8 Dec 1979 & 1232 & 665 & Reentry, temperature measurement, and water sample. & Downhole measurements & 0.63 \\
\hline 70 & 8 Dec 1979 & 1245 & 665 & Start coring bit Run 4, Core 50. & Reentry 7 , coring bit Run 4 , Cores $50-60$ & 2.00 \\
\hline 70 & 10 Dec 1979 & 1232 & 750.5 & End coring bit Run 4, Core 60. & & \\
\hline 70 & 11 Dec 1979 & 0750 & 750.5 & Reentry, temperature measurement, and water sample. & Downhole measurements & 0.80 \\
\hline 70 & 11 Dec 1979 & 0800 & 750.5 & Start coring bit Run 5, Core 61. & Reentry 8 , coring bit Run 5 , Cores $61-70$ & 1.85 \\
\hline 70 & 13 Dec 1979 & 0415 & 836 & End coring bit Run 5, Core 70. & & \\
\hline 70 & 13 Dec 1979 & 1055 & 836 & Downhole logging. & Reentry 9, downhole measurements & 3.42 \\
\hline 70 & 16 Dec 1979 & 1420 & 836 & End of downhole logging. & & \\
\hline 70 & & & & & Total: & 13.03 \\
\hline 83 & 23 Nov 1981 & 0632 & 836 & Reentry in hole, 2 years after previous operations. & & \\
\hline 83 & 23 Nov 1981 & 0632 & 836 & Temperature profile and water sampling. & Reentry 10 , downhole measurements & 1.27 \\
\hline 83 & 24 Nov 1981 & 1300 & 836 & Bowen hydraulic unit (heave compensator) lost hydraulic pressure. & & 0.24 \\
\hline 83 & 24 Nov 1981 & 1845 & 836 & Start coring bit Run 1, Core 71. & Reentry 11 , coring bit Run 6 , Cores $71-85$ & 1.65 \\
\hline 83 & 26 Nov 1981 & 1022 & 904.5 & Leak in stem between power sub and swivel; pipe tripped up to casing; $12 \mathrm{~h}$ lost. & & 0.50 \\
\hline 83 & 26 Nov 1981 & 2220 & 904.5 & Resume coring, Core 80. & & 0.58 \\
\hline 83 & 27 Nov 1981 & 1210 & 964.5 & End coring bit Run 1 , Core 85. & & \\
\hline 83 & 27 Nov 1981 & 1210 & 964.5 & Start coring bit Run 2, Core 86. & Reentry 12 , coring bit Run 7 , Cores $86-97$ & 3.21 \\
\hline 83 & 30 Nov 1981 & 1710 & 1057.5 & Core barrel (Core 96) left in hole; two fishing attempts. & & 0.12 \\
\hline 83 & 30 Nov 1981 & 2000 & 1062 & Resume coring. & & 0.16 \\
\hline 83 & 30 Nov 1981 & 2100 & 1062 & End coring bit Run 2, Core 97; broken pipe. & & \\
\hline 83 & 30 Nov 1981 & 2100 & 1062 & Broken pipe, $\mathrm{BHA}+39$ joints of drill pipe lost in hole. & Reentry 13 , fishing drill string & 1.09 \\
\hline 83 & 1 Dec 1981 & 2310 & 1062 & First attempt fishing broken pipe failed. & & \\
\hline 83 & 2 Dec 1981 & 2010 & 1062 & $\begin{array}{l}\text { Second attempt fishing broken pipe succeeded. } 2.5 \text { days lost; BHA ( } 4 \text { collars + coring assembly) } \\
\text { filled with finely ground basalt. }\end{array}$ & Reentry 14 , fishing drill string & 0.88 \\
\hline 83 & 4 Dec 1981 & 0643 & 1062 & Start coring bit Run 3, Core 98. & Reentry 15 , coring bit Run 8 , Cores $98-111$ & 4.40 \\
\hline 83 & 7 Dec 1981 & 0541 & 1166 & End coring bit Run 3, Core 111. & & \\
\hline 83 & 8 Dec 1981 & 0207 & 1166 & $\begin{array}{l}\text { Start coring bit Run 4, Core } 112 \text { (F94CK bit with smaller core guide, } 4.5 \text { m cores; no improved } \\
\text { core recovery). }\end{array}$ & Reentry 16 , coring bit Run 9, Cores $112-120$ & 2.68 \\
\hline 83 & 9 Dec 1981 & 2155 & 1207.5 & End coring bit Run 4, Core 120 (bit lost tungsten carbide inserts). & & \\
\hline 83 & 10 Dec 1981 & 2054 & 1207.5 & Start coring bit Run 5, Core 121 (back to previous bit type, with 2-7/16 inch size). & Reentry 17 , coring bit Run 10 , Cores $121-126$ & 2.47 \\
\hline 83 & 12 Dec 1981 & 0905 & 1253.5 & End coring bit Run 5, Core 126 (bit lost tungsten carbide inserts). & & \\
\hline 83 & 13 Dec 1981 & 0247 & 1253.5 & Start coring bit Run 6, Core 127 (F94CK bit). & Reentry 18 , coring bit Run 11 , Cores $127-130$ & 1.91 \\
\hline 83 & 14 Dec 1981 & 0700 & 1287.5 & End coring bit Run 6, Core 130; broken pipe. & & \\
\hline
\end{tabular}


Table T3 (continued). (Continued on next page).

\begin{tabular}{|c|c|c|c|c|c|c|}
\hline Leg & Date & $\begin{array}{c}\text { Time } \\
(h)\end{array}$ & $\begin{array}{l}\text { Depth } \\
\text { (mbsf) }\end{array}$ & Comment & Brief run description & $\begin{array}{l}\text { Time } \\
\text { (days) }\end{array}$ \\
\hline 83 & 14 Dec 1981 & 0700 & 1287.5 & Broken pipe, $\mathrm{BHA}+10$ joints of drill pipe lost in hole. & Reentry 19 , fishing drill string & 1.39 \\
\hline 83 & 15 Dec 1981 & 1626 & 1287.5 & Fishing broken pipe. 1.5 day lost; 2 days added to the leg! & & \\
\hline 83 & 16 Dec 1981 & 0820 & 1287.5 & Downhole logging. NB: cable stripped for sonic sonde. & Reentries 20-23, downhole measurements & 10.73 \\
\hline 83 & 20 Dec 1981 & 0805 & 1287.5 & $\begin{array}{l}\text { Downhole logging. NB: } 1 \text { bowspring of top centralizer of sonic sonde broke; } 1.5 \mathrm{~m} \text { piece lost in } \\
\text { hole. }\end{array}$ & & \\
\hline 83 & 23 Dec 1981 & 1443 & 1287.5 & Packer run. & & \\
\hline 83 & 25 Dec 1981 & 0106 & 1287.5 & Packer run. & & \\
\hline 83 & 26 Dec 1981 & 0952 & 1287.5 & Packer run. & & \\
\hline 83 & 28 Dec 1981 & 0536 & 1287.5 & Start coring bit Run 7, Core 131 (F94CK bit). NB: junk from logging tool wasn't fished. & Reentry 24 , coring bit Run 12 , Cores $131-135$ & 3.57 \\
\hline 83 & 29 Dec 1981 & 2337 & 1322 & End coring bit Run 7, Core 135. NB: BHA + Bowen power sub magnafluxed. & & \\
\hline 83 & 31 Dec 1981 & 0030 & 1322 & Start coring bit Run 8, Core 136. & Reentry 25 , coring bit Run 13 , Cores $136-141$ & 2.78 \\
\hline 83 & 1 Jan 1982 & 1815 & 1350 & End coring bit Run 8, Core 141. & & \\
\hline 83 & & & & & Total: & 39.61 \\
\hline 92 & 8 Apr 1983 & 0706 & 1350 & Reentry in Hole, 2 years after previous operations. & & \\
\hline 92 & 8 Apr 1983 & 0900 & 1350 & $\begin{array}{l}\text { Extensive downhole measurements and logging program. Oblique seismic experiment was an } \\
\text { ordeal (quoting the leg report); missing connectors for the seismometer + other floods and } \\
\text { failures. }\end{array}$ & Reentry 26 , downhole measurements & 8.63 \\
\hline 92 & 16 Apr 1983 & 2215 & 1350 & End of downhole measurements. & & \\
\hline 92 & & & & & Total: & 8.63 \\
\hline 111 & 30 Aug 1986 & 0000 & 1350 & Reentry in hole, 3 years after previous operations, 5 years after last coring. & & \\
\hline 111 & 30 Aug 1986 & 0000 & 1350 & Downhole logging and water sampling. & Reentry 27 , downhole measurements & 4.50 \\
\hline 111 & 3 Sep 1986 & 1200 & 1350 & RFT logging tool lost one clamping arm. & & \\
\hline 111 & 3 Sep 1986 & 1200 & 1352.8 & Junk mill run. Milled metal and rubber (packer from Leg 83 ). & Reentry 28 , milling metal junk & 3.08 \\
\hline 111 & 6 Sep 1986 & 1400 & 1352.8 & Start coring bit Run 1, Core 142 (F99CK bit). & Reentry 29 , coring bit Run 14 , Cores $142-147$ & 2.18 \\
\hline 111 & 8 Sep 1986 & 1815 & 1406.8 & End coring bit Run 1, Core 147 . NB: Core 147 stuck in BHA. & & \\
\hline 111 & 10 Sep 1986 & 1045 & 1406.8 & Packer run. Second packer damaged when $\mathrm{POOH}$. & Reentry 30, downhole measurements & 1.69 \\
\hline 111 & 11 Sep 1986 & 1100 & 1406.8 & $\begin{array}{l}\text { Start coring bit Run 2, Core } 148 \text { (RBI type C7). Difficult drilling conditions (good only when } \\
\text { high circulation rates maintained). }\end{array}$ & Reentry 31 , coring bit Run 15 , Cores $148-158$ & 3.33 \\
\hline 111 & 13 Sep 1986 & 1845 & 1488.1 & End coring bit Run 2, Core 158 . Junk still present at bottom, some recovered in boot basket. & & \\
\hline 111 & $14 \operatorname{Sep} 1986$ & 0245 & 1488.1 & BHA filled with cuttings during pipe trip down. Circulation lost. $\mathrm{POOH}$. & Reentry 32 , lost circulation & 2.72 \\
\hline 111 & $16 \operatorname{Sep} 1986$ & 1200 & 1488.1 & Start coring bit Run 3, Core 159 (C-57 bit). & Reentry 33 , coring bit Run 16 , Cores $159-161$ & 1.00 \\
\hline 111 & $17 \operatorname{Sep} 1986$ & 1200 & 1511.5 & End coring bit Run 3, Core 161. Bit failure. & & \\
\hline 111 & $17 \operatorname{Sep} 1986$ & 2000 & 1511.5 & Bit completely destroyed. Four cones and much of the steel core guide lost in hole. & Reentries 34 to 36 , milling and fishing metal junk & 4.20 \\
\hline 111 & 18 Sep 1986 & 0100 & 1511.5 & First of a series of three fishing pipe trips (junk baskets and mill). & & \\
\hline 111 & 21 Sep 1986 & 1645 & 1511.6 & End of fishing runs (mill Core 162M). & & \\
\hline 111 & $22 \operatorname{Sep} 1986$ & 1200 & 1511.6 & Start coring bit Run 4, Core 163 (DSDP/Smith F99CK bit). & Reentry 37 , coring bit Run 17 , Cores $163-167$ & 2.15 \\
\hline 111 & 23 Sep 1986 & 2015 & 1547.5 & End coring bit Run 4, Core 167 (last core stopped after $1.6 \mathrm{~m}$, core barrel not retrieved). & & \\
\hline 111 & $24 \operatorname{Sep} 1986$ & 0830 & 1547.5 & $\begin{array}{l}\text { Bit completely destroyed. Four cones lost; worse shape than previous one. Special fishing and } \\
\text { milling tools air-freighted to Ecuador and brought to JR by tuna vessel Sirius while logging } \\
\text { Hole 504B and coring Sites } 677 \text { and } 678 \text {. }\end{array}$ & Bit destroyed, waiting for fishing tools & 0.51 \\
\hline 111 & 24 Sep 1986 & 1000 & 1547.5 & Downhole experiments (packer, VSP) and logging. & Reentry 38 , downhole measurements & 5.93 \\
\hline 111 & 30 Sep 1986 & 0645 & 1547.5 & JR left Site 504 for coring sediments at Sites 677 and 678 for 5 days. & & \\
\hline 111 & 5 Oct 1986 & 0500 & 1547.6 & $\begin{array}{l}\text { Milling and fishing ( } 1 \text { junk basket run }+1 \text { mill run). Not much junk back in the basket ( } 3 \text { rocks, } \\
\text { no cone). Mill Core } 168 \mathrm{M} \text {. }\end{array}$ & Reentries 39 and 40 , milling and fishing metal junk & 3.21 \\
\hline 111 & 8 Oct 1986 & 1000 & 1547.6 & Start coring bit Run 5, Core 169 (DSDP/Smith F99CK bit). & Reentry 41 , coring bit Run 18 , Cores $169-170$ & 0.81 \\
\hline 111 & 9 Oct 1986 & 0530 & 1562.1 & $\begin{array}{l}\text { End coring bit Run 5, Core 170. Bad drilling condition during Core 170R; bit returned worn but } \\
\text { in one piece. }\end{array}$ & & \\
\hline
\end{tabular}


Table T3 (continued). (Continued on next page).

\begin{tabular}{|c|c|c|c|c|c|c|}
\hline Leg & Date & $\begin{array}{c}\text { Time } \\
(h)\end{array}$ & $\begin{array}{l}\text { Depth } \\
\text { (mbsf) }\end{array}$ & Comment & Brief run description & $\begin{array}{l}\text { Time } \\
\text { (days) }\end{array}$ \\
\hline 111 & 9 Oct 1986 & 0530 & 1562.1 & Bit in very worn condition, with much damage from junk, but in one piece. & Reentry 42 , milling metal junk with newly arrived tool & 7.51 \\
\hline 111 & 9 Oct 1986 & & 1562.1 & Arrival of Ecuadorian tuna vessel Sirius with new fishing and milling equipment. & & \\
\hline 111 & & & 1562.1 & New flat-bottom junk mill run with two baskets. & & \\
\hline 111 & & & 1562.1 & $\begin{array}{l}\text { Diamond core bit run ( } 9-27 / 32 \text { inch NOR Geoset diamond core bit). Bit + float valve + lower } \\
\text { support bearing + inner core barrel lost in hole. }\end{array}$ & Reentry 43 , diamond coring bit lost & \\
\hline 111 & & & 1562.1 & Start of four fishing pipe trips; first one retrieved the core barrel. & Reentries $44-47$, fishing metal junk & \\
\hline 111 & 16 Oct 1986 & 1745 & 1562.1 & End of fishing runs; junk remained in the hole. & & \\
\hline 111 & & & & & Total: & 42.81 \\
\hline 137 & 7 Apr 1991 & 1800 & 1562.1 & Reentry in hole, 4.5 years after previous operations. & & \\
\hline 137 & 7 Apr 1991 & 1800 & 1562.1 & Downhole logging and water sampling & Reentry 48 , downhole measurements & 2.38 \\
\hline 137 & 10 Apr 1991 & 0300 & 1562.1 & End of initial logging & & \\
\hline 137 & 10 Apr 1991 & 0300 & 1570 & $\begin{array}{l}\text { Remedial/cleanout operations. First use of Bowen full-flow reverse circulation junk basket (little } \\
\text { junk recovered) followed by five successive milling runs and by a tricone Smith F7 run (hole } \\
\text { deepened to } 1570 \mathrm{mbsf} \text { ). Milling and drilling Cores } 171 \mathrm{M} \text { and } 172 \mathrm{M} \text {. }\end{array}$ & Reentries 49-55, fishing and milling metal junk, cleanout & 8.88 \\
\hline 137 & 19 Apr 1991 & 0000 & 1570 & Start coring bit Run 1, Core 173 (RBI C7 bit). & Reentry 56 , coring bit Run 19 , Cores $173-175$ & 1.58 \\
\hline 137 & 19 Apr 1991 & 1945 & 1595.3 & End coring bit Run 1, Core 175. Broken inserts. & & \\
\hline 137 & 20 Apr 1991 & 1400 & 1595.3 & Start coring bit Run 2, Core 176 (RBI C7 bit). & Reentry 57 , coring bit Run 20 , Cores $176-178$ & 2.40 \\
\hline 137 & 21 Apr 1991 & 1100 & 1615.5 & End coring bit Run 2, Core 178. Drive rows destroyed on all cones. & & \\
\hline 137 & 22 Apr 1991 & 2330 & 1618.4 & Cleanup run with tricone bit and junk baskets (Core 179M). & Reentry 58 , cleanout & 0.94 \\
\hline 137 & 23 Apr 1991 & 2200 & 1618.4 & Start coring bit Run 3, Core $180 \mathrm{M}$. Test of diamond coring (7-7/8 inch Hobic core bit). & Reentry 59 , coring bit Run 21 (diamond bit), Core $180 \mathrm{M}$ & 0.27 \\
\hline 137 & 24 Apr 1991 & 0430 & 1620.4 & $\begin{array}{l}\text { End coring bit Run 3, Core } 180 \mathrm{M} \text {. Very low penetration, good recovery (55\%). Bit completely } \\
\text { worn. }\end{array}$ & & \\
\hline 137 & 24 Apr 1991 & 0430 & 1620.4 & Start coring bit Run 4, Core 181M. Test of diamond coring (7-7/8 inch Christensen mining bit). & Reentry 60 , coring bit Run 22 (diamond bit), Core $181 \mathrm{M}$ & 1.08 \\
\hline 137 & 25 Apr 1991 & 0630 & 1621.5 & End coring bit Run 4 , Core $181 \mathrm{M}$. Very low penetration, good recovery $(123 \% !)$. & & \\
\hline 137 & 25 Apr 1991 & 0630 & 1621.5 & $60 \mathrm{ft}$ outer barrel + bit lost in hole. & Reentries $61-63$, fishing metal junk & 1.23 \\
\hline 137 & & & 1621.5 & Start of remedial/cleanout operations. Three attempts failed. Overshot assembly lost in hole. & & \\
\hline 137 & & & 1621.5 & No more appropriate fishing tool available on board. Modification of available tool. & Reentry 64 , fishing metal junk & \\
\hline 137 & & & 1621.5 & New fishing attempt failed. & & \\
\hline 137 & 26 Apr 1991 & 1200 & 1621.5 & Downhole logging (BHTV) and flowmeter/packer experiment. & Reentry 65 , downhole measurements & 2.59 \\
\hline 137 & 29 Apr 1991 & 0215 & 1621.5 & End of logging; departure from Site 504. & & \\
\hline 137 & & & & & Total: & 21.34 \\
\hline 140 & 1 Oct 1991 & 1430 & 1621.5 & Reentry in hole, 5 months after previous operations. & & \\
\hline 140 & 1 Oct 1991 & 1430 & 1621.5 & Downhole logging. & Reentry 66 , downhole measurements & 0.90 \\
\hline 140 & 2 Oct 1991 & 1200 & 1621.5 & FMS arm, bowspring, and pad parts lost in hole. & & \\
\hline 140 & & & 1621.5 & $\begin{array}{l}\text { Three more fishing runs with different tools (spears + grapples, tapper tap). Grapple lost in hole } \\
\text { at end of third attempt. }\end{array}$ & Reentries $67-71$, fishing metal junk & 10.50 \\
\hline 140 & & & 1621.5 & Other attempt with tapper tap (shorter nose), failed. & & \\
\hline 140 & & & 1621.5 & $\begin{array}{l}\text { Fishing run with ship-built "double dog" fishing tool. Recovered part of the fish; diamond- } \\
\text { impregnated bit, near-bit bottom stabilizer, FMS parts, and miscellaneous small pieces of junk } \\
\text { left in hole. }\end{array}$ & & \\
\hline 140 & & & 1621.5 & $9-7 / 8$ inch tricone cleanout run. & Reentry 72 , cleanout & \\
\hline 140 & & & 1621.5 & Taper tap fishing run. Recovered rest of the fish. & Reentry 73 , fishing metal junk & \\
\hline 140 & & & 1621.8 & 9-7/8 inch tricone cleanout run (Core $184 \mathrm{M})$. & Reentry 74 , cleanout & \\
\hline 140 & 13 Oct 1991 & 0000 & 1621.8 & Start coring bit Run 1, Core 185 . New type of 9-7/8 inch H87F bits. & Reentry 75 , coring bit Run 23 , Cores $185-189$ & 1.71 \\
\hline 140 & 14 Oct 1991 & 1705 & 1655.1 & End coring bit Run 1, Core 189 . & & \\
\hline 140 & 14 Oct 1991 & 1705 & 1655.1 & Start coring bit Run 2, Core 190. & Reentry 76, coring bit Run 24, Cores 190-195 & 2.37 \\
\hline 140 & 17 Oct 1991 & 0200 & 1696.5 & End coring bit Run 2, Core 195. & & \\
\hline 140 & 17 Oct 1991 & 0200 & 1696.5 & Start coring bit Run 3, Core 196. & Reentry 77 , coring bit Run 25 , Cores $196-198$ & 1.99 \\
\hline 140 & 19 Oct 1991 & 0150 & 1719.4 & End coring bit Run 3, Core 198. & & \\
\hline 140 & 19 Oct 1991 & 0150 & 1719.4 & Start coring bit Run 4, Core 199. & Reentry 78, coring bit Run 26, Cores 199-204 & 3.33 \\
\hline 140 & 22 Oct 1991 & 0950 & 1757 & End coring bit Run 4, Core 204. & & \\
\hline
\end{tabular}


Table T3 (continued). (Continued on next page).

\begin{tabular}{|c|c|c|c|c|c|c|}
\hline Leg & Date & $\begin{array}{c}\text { Time } \\
(h)\end{array}$ & $\begin{array}{l}\text { Depth } \\
\text { (mbsf) }\end{array}$ & Comment & Brief run description & $\begin{array}{l}\text { Time } \\
\text { (days) }\end{array}$ \\
\hline 140 & 22 Oct 1991 & 0950 & 1757 & Start coring bit Run 5, Core 205. & Reentry 79, coring bit Run 27 , Cores 204-211 & 3.00 \\
\hline 140 & 25 Oct 1991 & 0950 & 1806 & End coring bit Run 5, Core 211. & & \\
\hline 140 & 25 Oct 1991 & 0950 & 1806 & Start coring bit Run 6, Core 212. & Reentry 80 , coring bit Run 28 , Cores $212-219$ & 3.07 \\
\hline 140 & 28 Oct 1991 & 1135 & 1865.5 & End coring bit Run 6, Core 219. & & \\
\hline 140 & 28 Oct 1991 & 1135 & 1865.5 & Start coring bit Run 7, Core 220. & Reentry 81 , coring bit Run 29 , Cores $220-225$ & 3.06 \\
\hline 140 & 31 Oct 1991 & 1255 & 1920 & End coring bit Run 7, Core 225 . & & \\
\hline 140 & 31 Oct 1991 & 1255 & 1920 & Start coring bit Run 8 , Core 226. & Reentry 82 , coring bit Run 30 , Cores $226-231$ & 2.48 \\
\hline 140 & 3 Nov 1991 & 0030 & 1957.3 & End coring bit Run 8 , Core 231 . All driver-row inserts on all cones chipped $80 \%$. & & \\
\hline 140 & 3 Nov 1991 & 0030 & 1957.3 & Start coring bit Run 9, Core 232. & Reentry 83 , coring bit Run 31 , Cores $232-235$ & 2.23 \\
\hline 140 & 5 Nov 1991 & 0600 & 1980.7 & End coring bit Run 9 , Core 235 . Inner $80 \%$ of each cone missing. & & \\
\hline 140 & 5 Nov 1991 & 0600 & 1980.7 & Start coring bit Run 10, Core 236. & Reentry 84 , coring bit Run 32 , Cores $236-238$ & 1.45 \\
\hline 140 & 6 Nov 1991 & 1650 & 2000.4 & $\begin{array}{l}\text { End coring bit Run } 10 \text {, Core } 238 \text {. Bit } 3 / 16 \text { inch under gauge and teeth broken or chipped due } \\
\text { to junk already in hole. }\end{array}$ & & \\
\hline 140 & 7 Nov 1991 & 0500 & 2000.4 & Downhole logging. & Reentry 85 , downhole measurements & 3.46 \\
\hline 140 & 10 Nov 1991 & 0350 & 2000.4 & End of logging. & & \\
\hline 140 & & & & & Total: & 39.56 \\
\hline 148 & $28 \operatorname{Jan} 1993$ & 0450 & 2000.4 & Reentry in hole, 1 year and 3 months after previous operations. & & \\
\hline 148 & 28 Jan 1993 & 0450 & 2000.4 & Downhole logging (temperature + water sampling). & Reentry 86 , downhole measurements & 2.63 \\
\hline 148 & 30 Jan 1993 & 2000 & 2000.4 & Start coring bit Run 1 Core 239 . Security 9-7/8 inch rotary coring bit. & & \\
\hline 148 & 1 Feb 1993 & 1635 & 2038.2 & End coring bit Run 1 Core 243. & Reentry 87 , coring bit Run 33 , Core 243 & 1.86 \\
\hline 148 & 1 Feb 1993 & 1635 & 2038.2 & One cone + roller bearings lost in hole. & & \\
\hline 148 & 1 Feb 1993 & 1635 & 2038.2 & $\begin{array}{l}\text { Milling run with junk basket. Large pieces of bit-cone material retrieved }+3 \text { bearings, } 16 \text { inserts, } \\
\text { klusterite from the mill, and } 173 \mathrm{~g} \text { of miscellaneous junk. }\end{array}$ & Reentry 88 , milling metal junk & 1.78 \\
\hline 148 & 3 Feb 1993 & 1120 & 2038.2 & Start coring bit Run 2, Core 244 (RBI C9 bit + junk basket). & Reentry 89 , coring bit Run 34 , Cores $244-246$ & 1.39 \\
\hline 148 & 4 Feb 1993 & 2035 & 2056.7 & $\begin{array}{l}\text { End coring bit Run 2, Core } 246 \text {. Teeth and middle rows of all cones broken. Junk basket } \\
\text { recovered } 660 \mathrm{~g} \text { of metal, including } 3 \text { large pieces from the cone noses and } 11 \text { bit inserts. }\end{array}$ & & \\
\hline 148 & 4 Feb 1993 & 2035 & 2056.7 & Start coring bit Run 3, Core 247 (RBI C9 bit + junk basket). & Reentry 90 , coring bit Run 35 , Cores $247-248$ & 1.16 \\
\hline 148 & 6 Feb 1993 & 0025 & 2061.8 & $\begin{array}{l}\text { End coring bit Run 3, Core } 248 \text {. Teeth cracked in the middle row of two cones, small inserts lost. } \\
\text { Junk basket recovered } 94 \mathrm{~g} \text { of metal. }\end{array}$ & & \\
\hline 148 & 6 Feb 1993 & 0025 & 2061.8 & Start coring bit Run 4, Core 249 (RBI C7 bit + junk basket). & Reentry 91 , coring bit Run 36 , Cores $249-250$ & 1.12 \\
\hline 148 & 7 Feb 1993 & 0315 & 2089.9 & $\begin{array}{l}\text { End coring bit Run } 4 \text {, Core } 250 \text {. Teeth on the heel rows of three cones chipped, small inserts } \\
\text { missing. Junk basket recovered } 86 \mathrm{~g} \text { of metal. }\end{array}$ & & \\
\hline 148 & 7 Feb 1993 & 0315 & 2089.9 & Start coring bit Run 5, Core 251 (RBI C9 bit). & Reentry 92 , coring bit Run 37 , Cores $251-253$ & 2.46 \\
\hline 148 & 9 Feb 1993 & 1415 & 2111 & End coring bit Run 5, Core 253. & & \\
\hline 148 & 9 Feb 1993 & 1415 & 2111 & $\begin{array}{l}\text { Pipe stuck and severed. BHA left in hole. Operations discontinued until the arrival of a fishing } \\
\text { consultant and a shipment of fishing tools. }\end{array}$ & $\begin{array}{l}\text { Severing the drill string; waiting for fishing consultant and } \\
\text { tools }\end{array}$ & 1.91 \\
\hline 148 & 11 Feb 1993 & 1200 & 2111 & Drilling at site 896 for $\sim 9$ days. & & \\
\hline 148 & 20 Feb 1993 & 1200 & 2111 & Return to Hole 504B to meet the boat bringing fishing consultant and equipment. & & 6.56 \\
\hline 148 & 21 Feb 1993 & & 2111 & $\begin{array}{l}\text { Fishing run with Bowen super jar. BHA retrieved; bit, float valve, and lower support bearing left } \\
\text { in hole, together with two pieces of schlumberger explosive rod. }\end{array}$ & Reentry 93 , fishing drill string & \\
\hline 148 & 22 Feb 1993 & & 2111 & $\begin{array}{l}\text { Milling run with Petco concave mill, with junk baskets and bowen super jar. Bottom of mill } \\
\text { completely worn; baskets recovered }>1.7 \mathrm{~kg} \text { of metal. }\end{array}$ & Reentry 94 , milling drill string & \\
\hline 148 & & & 2111 & $\begin{array}{l}\text { Milling run with same configuration as previous one. Petco mill, } 2 \text { junk baskets, bit sub, } 3 \text { drill } \\
\text { collars, and } 0.38 \mathrm{~m} \text { of Bowen super jar joined the collection of junk in the hole! }\end{array}$ & Reentry 95, milling drill string; more junk in the hole! & \\
\hline 148 & 24 Feb 1993 & & 2111 & $\begin{array}{l}\text { Last fishing run; retrieved the fish. Coring bit, float valve, and lower support bearing still in hole. } \\
\text { The second mill showed no evidence off having milled anything. Borehole had collapsed, } \\
\text { depositing } 19 \mathrm{~m} \text { of rubble on top of the remaining fish. }\end{array}$ & $\begin{array}{l}\text { Reentry } 96 \text {, fishing drill string + milling tool; coring bit, } \\
\text { float valve, and lower support bearing left in hole }\end{array}$ & \\
\hline 148 & 27 Feb 1993 & 0130 & 2111 & Downhole logging. & Reentry 97 , downhole measurements & 2.44 \\
\hline 148 & 1 Mar 1993 & 1200 & 2111 & JR departed for additional coring at site 896 for $\sim 3$ days. & & \\
\hline 148 & 4 Mar 1993 & 1200 & 2111 & Water sample + VSP. & Reentry 98 , downhole measurements & 2.00 \\
\hline
\end{tabular}


Table T3 (continued).

\begin{tabular}{|c|c|c|c|c|c|c|}
\hline Leg & Date & $\begin{array}{c}\text { Time } \\
\text { (h) }\end{array}$ & $\begin{array}{l}\text { Depth } \\
\text { (mbsf) }\end{array}$ & Comment & Brief run description & $\begin{array}{c}\text { Time } \\
\text { (days) }\end{array}$ \\
\hline 148 & 6 Mar 1993 & 1200 & 2111 & $\begin{array}{l}\text { End of operations in Hole 504B. Final sentence of the coring operations section in the Leg } 148 \\
\text { site chapter: "With the proper equipment, milling operations on a return trip to Hole 504B } \\
\text { would be simple and straightforward...." }\end{array}$ & End of Hole 504B & \\
\hline 148 & & & & & Total: & 25.31 \\
\hline 504B & & & & & Total: & 205.74 \\
\hline
\end{tabular}

Times have sometimes been estimated based on average rates of penetration or on average pipe trip duration, as they were not always available in the operation section of the Site 504 chapter

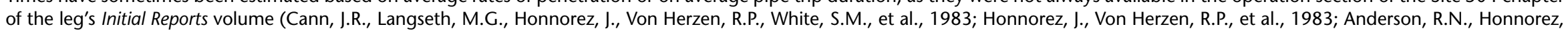
J., Becker, K., et al., 1985; Shipboard Scientific Party, 1986, 1988, 1992a, 1992b, 1993). Gray = beginning and end of legs, casing operations; blue = downhole measurements; green = coring; red $=$ hardware failure and hole remediation. $\mathrm{BHA}=$ bottom-hole assembly, RFT $=$ retrievable formation tester, $\mathrm{POOH}=$ pull out of hole, JR $=$ JOIDES Resolution, $\mathrm{VSP}=$ vertical seismic profile, NOR = Geoset diamond core bit, BHTV = Borehole Televiewer tool, FMS = Formation MicroScanner. This table is available in ASCII and in Microsoft Excel format (see 104 T3.XLS in CHAPTER_104 in TABLES in "Supplementary material"). 
Table T4. Summary of operations at Hole 1256D (ODP Leg 206; IODP Expeditions 309/312 and 335). (Continued on next eight pages.)

\begin{tabular}{|c|c|c|c|c|c|c|}
\hline Leg & Date & Time & $\begin{array}{l}\text { Depth } \\
\text { (mbsf) }\end{array}$ & Comment & Brief run description & $\begin{array}{l}\text { Time } \\
\text { (days) }\end{array}$ \\
\hline 206 & 23 Nov 2002 & 0345 & 0 & Spud reentry cone and jet-in 20 inch casing. & Initiate Hole 1256D, 20 inch casing & 1.69 \\
\hline 206 & 24 Nov 2002 & 1035 & 95 & End jetting. Reach 95 mbsf; release CADA. & & \\
\hline 206 & 24 Nov 2002 & 2015 & 95 & Bit at rotary table. Change to BCR BHA. & & \\
\hline 206 & 25 Nov 2002 & 0815 & 95 & Drill 21-1/2 inch hole at 95 mbsf. & & \\
\hline 206 & 27 Nov 2002 & 0445 & 267 & End drilling at $\sim 17 \mathrm{~m}$ into basement. & Reentry 1 , drilling 21.5 inch hole into basement & 2.70 \\
\hline 206 & 27 Nov 2002 & 1300 & 267 & Bit at rotary table. Failed bit bearing left junk in hole. & & \\
\hline 206 & 28 Nov 2002 & 0000 & 267 & Cleaning, work 2 junk baskets. & Reentry 2, cleanout & 0.94 \\
\hline 206 & 28 Nov 2002 & 0330 & 268 & End cleaning, advance $1 \mathrm{~m}$ into basement. & & \\
\hline 206 & 28 Nov 2002 & 1140 & 268 & Bit at rotary table. Change to BCR BHA. & & \\
\hline 206 & 28 Nov 2002 & 2000 & 268 & Resume drilling 21-1/2 inch hole at $17 \mathrm{~m}$ in basement. & Reentry 3, drilling 21.5 inch hole into basement & 2.08 \\
\hline 206 & 30 Nov 2002 & 0030 & 276.1 & Begin wiper trip. $\mathrm{TD}=276.1 \mathrm{mbsf}$ ( $26.1 \mathrm{~m}$ in basement). & & \\
\hline 206 & 30 Nov 2002 & 0415 & 276.1 & Displace hole with $150 \mathrm{bbl}$ sepiolite and $100 \mathrm{bbl}$ barite. & & \\
\hline 206 & 30 Nov 2002 & 1330 & 276.1 & Bit at rotary table. Rig-up for 16 inch casing. & & \\
\hline 206 & 1 Dec 2002 & 0417 & 276.1 & Casing wet at $0417 \mathrm{~h}$. & Reentry 4, casing & 0.88 \\
\hline 206 & 1 Dec 2002 & 1040 & 276.1 & Detect crushed joint. Stop running casing. & & \\
\hline 206 & 2 Dec 2002 & 0004 & 276.1 & Recover casing. Replace 4 joints and casing collar. & Replace casing & 1.04 \\
\hline 206 & 2 Dec 2002 & 1135 & 276.1 & Casing wet at $1135 \mathrm{~h}$. & Reentry 4, casing, WOW & 0.80 \\
\hline 206 & 2 Dec 2002 & 2008 & 276.1 & Reentry 4 . Weather getting bad; heave $=\sim 2.5 \mathrm{~m}$. & & \\
\hline 206 & 2 Dec 2002 & 2315 & 276.1 & Clear seafloor. $\mathrm{POOH}$ due to heave $=\sim 4 \mathrm{~m}$. & & \\
\hline 206 & 3 Dec 2002 & 0650 & 276.1 & Reentry. WOW for $5.75 \mathrm{~h}$. & WOW & \\
\hline 206 & 3 Dec 2002 & 1730 & 276.1 & Land casing. Work stuck casing for $3.75 \mathrm{~h}$. & & \\
\hline 206 & 3 Dec 2002 & 1745 & 276.1 & Cement casing with $30 \mathrm{bbl}$ cement. & Reentry 5, cement casing & 0.92 \\
\hline 206 & 4 Dec 2002 & 0500 & 276.1 & CADA tool on surface. & & \\
\hline 206 & 4 Dec 2002 & 0630 & 276.1 & Begin to run in hole. Coring Bit 1: CC4 SN BX-020. & & 1.20 \\
\hline 206 & 4 Dec 2002 & 1815 & 276.1 & Start to drill cement. Attempted core/dropped chisel. & Reentry 6 , coring Bit 1 , coring cement & \\
\hline 206 & 5 Dec 2002 & 0955 & 276.1 & Tested bottom of hole and found junk. & & 0.26 \\
\hline 206 & 5 Dec 2002 & 1615 & 276.1 & Bit at rotary table. & & \\
\hline 206 & 6 Dec 2002 & 0230 & 276.1 & Start fishing with Bowen fishing magnet. Work junk baskets and magnet $1 \mathrm{~h}$. & Reentry 7 , fishing metal junk & 0.80 \\
\hline 206 & 6 Dec 2002 & 1130 & 276.1 & Bit at rotary table. Clean magnet. & & \\
\hline 206 & 7 Dec 2002 & 0045 & 276.1 & Work junk basket before coring. & Reentry 8, coring Bit 2, Cores 2R-21R & 4.38 \\
\hline 206 & 7 Dec 2002 & 0100 & 276.1 & Begin coring Bit 2 (clean hole), CC-7 SN BP-723. Cores 2R-21R. & & \\
\hline 206 & 10 Dec 2002 & 1203 & 406 & Work stuck pipe (stuck when sinker bars pulled). & & \\
\hline 206 & 10 Dec 2002 & 2040 & 406 & Bit at rotary table: $\mathrm{hr}=49.58$; cored $=129.9 \mathrm{~m}(158.0 \mathrm{~m}$ in basement $)$. & & \\
\hline 206 & 11 Dec 2002 & 0845 & 406 & Begin coring Bit 3 (Bit 3: CC-7 SN BP-737). Cores 22R-35R. & Reentry 9, coring Bit 3, Cores 22R-35R & 4.43 \\
\hline 206 & 15 Dec 2002 & 0655 & 494 & Bit at rotary table: $\mathrm{hr}=62.9$; cored $=88.0 \mathrm{~m}(244.0 \mathrm{~m}$ in basement). & & \\
\hline 206 & 15 Dec 2002 & 1800 & 494 & Begin coring Bit 4 (Bit 4: CC-9 SN BF-857, no junk basket). & Reentry 10 , coring Bit 4, Cores 36R-46R & 4.03 \\
\hline 206 & 19 Dec 2002 & 0740 & 571 & Bit at rotary table: $\mathrm{hr}=57.8$; cored $=77.0 \mathrm{~m}$ (321.0 $\mathrm{m}$ in basement). Cores $36 \mathrm{R}-46 \mathrm{R}$. & & \\
\hline 206 & 19 Dec 2002 & 1915 & 571 & Begin coring Bit 5 (Bit 5: CC-9 SN BF-738). 3 m soft fill. & Reentry 11 , coring Bit 5, Cores $47 \mathrm{R}-57 \mathrm{R}$ & 3.95 \\
\hline 206 & 23 Dec 2002 & 0625 & 655 & Bit at rotary table: $\mathrm{hr}=59.4$; cored $=84.0 \mathrm{~m}$ (405.0 m basement). Cores 47R-57R. & & \\
\hline 206 & 23 Dec 2002 & 1845 & 655 & Begin coring Bit 6 (Bit 6: CC-9 SN BF-740). Cores 58R-74R. & Reentry 12 , coring Bit 6 , Cores $58 \mathrm{R}-74 \mathrm{R}$ & 4.69 \\
\hline 206 & 27 Dec 2002 & 2300 & 752 & Bit at rotary table: $\mathrm{hr}=64.9$; cored $=97.0 \mathrm{~m}(502.0 \mathrm{~m}$ basement $)$. & & \\
\hline 206 & 28 Dec 2002 & 0622 & 752 & Reentry 13 (logging BHA). Rig-up for logging. & Reentry 13 , downhole measurements & 3.18 \\
\hline 206 & 30 Dec 2002 & 2030 & 752 & Rig-down from logging. BGRM did not work; 2 runs. Triple combo, FMS, BGRM, UBI, WST. & & \\
\hline 206 & 31 Dec 2002 & 0325 & 752 & Bit at rotary table. & & \\
\hline 206 & 31 Dec 2002 & 0330 & 752 & Beacon recovered after 45 days. Under way to Balboa. & & \\
\hline 206 & & & & & & Total: \\
\hline 309 & $16 \mathrm{Jul} 2005$ & 1945 & 752 & Hole reentered 2.5 years after previous operations. & & \\
\hline 309 & $17 \mathrm{Jul} 2005$ & 0030 & 752 & WSTP and APCT runs. & Reentry 14 , downhole measurements & 1.41 \\
\hline 309 & 17 Jul 2005 & 1015 & 752 & Rig up logging equipment & & \\
\hline 309 & 18 Jul 2005 & 0530 & 752 & End logging (triple combo, FMS). & & \\
\hline
\end{tabular}


Table T4 (continued). (Continued on next page).

\begin{tabular}{|c|c|c|c|c|c|c|}
\hline Leg & Date & Time & $\begin{array}{l}\text { Depth } \\
\text { (mbsf) }\end{array}$ & Comment & Brief run description & $\begin{array}{l}\text { Time } \\
\text { (days) }\end{array}$ \\
\hline 309 & 18 Jul 2005 & 1500 & 752 & Begin RCB coring Bit 1, Cores 75R-85R. & Reentry 15 , coring Bit 7, Cores $75 \mathrm{R}-85 \mathrm{R}$ & 4.19 \\
\hline 309 & 22 Jul 2005 & 1000 & 821 & Bit 1 on deck. Two trimming inserts missing from one cone, $1 / 16$ inch under gauge. & & \\
\hline 309 & 22 Jul 2005 & 1200 & 821 & Begin coring Bit 2 (C9), Core 86R. & Reentry 16 , coring Bit 8 , Core $86 \mathrm{R}$ & 0.86 \\
\hline 309 & 23 Jul 2005 & 0635 & 830.6 & $\begin{array}{l}\text { All core catcher dogs missing; some core fell out of the drill string. Next barrel pulled after } \\
\text { noting high pump pressures; deplugger deployed twice. }\end{array}$ & Core catcher fingers missing & 0.17 \\
\hline 309 & 23 Jul 2005 & 1045 & 830.6 & Resume coring, Cores 87R-96R. & Cores 87R-96R & 2.91 \\
\hline 309 & 26 Jul 2005 & 0830 & 897.8 & Coring Bit 8 on deck. Some broken inserts, $3 / 16$ inch under gauge. & & \\
\hline 309 & 26 Jul 2005 & 1000 & 897.8 & Begin coring Bit 3 (BF-854), Cores 97R-107R. & Reentry 17 , coring Bit 9 , Cores $97 \mathrm{R}-107 \mathrm{R}$ & 3.65 \\
\hline 309 & 30 Jul 2005 & 0000 & 958.8 & Coring Bit 3 on deck. One broken insert, $1 / 4$ inch under gauge. & & \\
\hline 309 & 30 Jul 2005 & 1000 & 958.8 & WSTP sample. & & 0.20 \\
\hline 309 & 30 Jul 2005 & 1445 & 958.8 & Begin coring Bit 4 (BF-856), Cores 108R-111R. & Reentry 18 , coring Bit 10 , Cores $108 \mathrm{R}-111 \mathrm{R}$ & 1.18 \\
\hline 309 & $31 \mathrm{Jul} 2005$ & 0905 & 974.4 & $\begin{array}{l}\text { After retrieving Core } 110 \mathrm{R} \text {, pressure drop after dropping core barrel. Core barrel pulled, } \\
\text { deplugger deployed. Pressure still lower than normal. }\end{array}$ & & 1.51 \\
\hline 309 & $31 \mathrm{Jul} 2005$ & 1745 & 979.2 & $\begin{array}{l}\text { While retrieving Core } 111 \mathrm{R} \text {, pressure drop noted again }(\sim 200-250 \text { psi) when lifting BHA } \\
\text { off bottom. Pressure increased when weight applied, indicating a crack in BHA. Crack } \\
\sim 300^{\circ} \text { of the circumference of the } 3 / 4 \text { inch thick bit sub wall ( } 15 \text { inches from the bit). }\end{array}$ & & \\
\hline 309 & 1 Aug 2005 & 0300 & 979.2 & Coring Bit 10 on deck. One broken insert, $\sim 3 / 16$ inch under gauge. & & \\
\hline 309 & 1 Aug 2005 & 0630 & 972.2 & Begin coring Bit 5 (BF-858), Cores 112R-126R. & Reentry 19 , coring Bit 11 , Cores $112 \mathrm{R}-126 \mathrm{R}$ & 3.96 \\
\hline 309 & 5 Aug 2005 & 0200 & 1051.3 & Coring Bit 5 on deck. One broken insert, one missing insert, 1/16 inch under gauge. & & \\
\hline 309 & 5 Aug 2005 & 0215 & 1051.3 & Begin coring Bit 6 (BF-741), Cores 127R-138R. & Reentry 20 , coring Bit 12 , Cores $127 \mathrm{R}-138 \mathrm{R}$ & 3.67 \\
\hline 309 & 8 Aug 2005 & 1800 & 1108.9 & $\begin{array}{l}\text { Bit } 12 \text { on deck. One broken insert, one missing insert, 1/16 inch under gauge. Three } \\
\text { gauge inserts missing, all from the same row. }\end{array}$ & & \\
\hline 309 & 8 Aug 2005 & 1815 & 1108.9 & Begin coring Bit 7 (BF-742), Cores 139R-146R. & Reentry 21 , coring Bit 13 , Cores $139 \mathrm{R}-146 \mathrm{R}$ & 2.81 \\
\hline 309 & 11 Aug 2005 & 1330 & 1145.2 & $\begin{array}{l}\text { While cutting Core } 146 \mathrm{R} \text {, pressure drop noted }(100 \mathrm{psi}) ; 350 \mathrm{psi} \text { pressure drop noted } \\
\text { when drill string pulled off bottom. Core } 146 \mathrm{R} \text { recovered. POOH. }\end{array}$ & & 0.40 \\
\hline 309 & 11 Aug 2005 & 2300 & 1145.2 & BHA on deck. All drill collars and subs inspected. No cracks in BHA. & & \\
\hline 309 & 12 Aug 2005 & 0415 & 1145.2 & Begin coring Bit 8 (BF-853). & & 0.61 \\
\hline 309 & 12 Aug 2005 & 1345 & 1145.2 & $\begin{array}{l}\text { Check drill string for cracks with VIT + high-vis mud pill (no pressure increase while filling } \\
\text { with seawater every } 25 \text { stands). Jet of drilling mud (crack) seen streaming from the } 5 \\
\text { inch pipe } \sim 2 \text { stands above the } 5-1 / 2 \text { inch transition pipe. }\end{array}$ & & 0.74 \\
\hline 309 & 12 Aug 2005 & 2030 & 1145.2 & Drill string pulled back and bottom 2 stands of 5 inch pipe replaced. & & \\
\hline 309 & 13 Aug 2005 & 0730 & 1145.2 & Resume coring, Cores 147R-158R. & Reentry 22 , coring Bit 14 , Cores $147 \mathrm{R}-158 \mathrm{R}$ & 3.51 \\
\hline 309 & 16 Aug 2005 & 1945 & 1203.8 & $\begin{array}{l}\text { Bit } 8 \text { on deck. Lost } \sim 2 / 3 \text { of gauge cutters on } 1 \text { cone, } 2 \text { cones lost core trimming cutters. } \\
\text { Bearings of } 3 \text { cones very loose; } 1 \text { cone could not be turned. }\end{array}$ & & \\
\hline 309 & 16 Aug 2005 & 2000 & 1203.8 & Deploy coring Bit 9 (CL-540), Cores 159R-170R. & Reentry 23 , coring Bit 15 , Cores $159 \mathrm{R}-170 \mathrm{R}$ & 4.26 \\
\hline 309 & 20 Aug 2005 & 1040 & 1255.1 & Wiper trip. & & \\
\hline 309 & 21 Aug 2005 & 0200 & 1255.1 & Bit 15 on deck. Some inserts missing from the cones, 4 gauge cutters missing. & & \\
\hline 309 & 21 Aug 2005 & 0800 & 1255.1 & Reentry for logging. & Reentry 24 , downhole measurements & 3.46 \\
\hline 309 & 24 Aug 2005 & 0500 & 1255.1 & Logging completed (triple combo, FMS-sonic, UBI, WST). & & \\
\hline 309 & 24 Aug 2005 & 1300 & 1255.1 & Depart location. & & \\
\hline 309 & & & & & Total: & 38.72 \\
\hline 312 & 15 Nov 2005 & 0730 & & Hole reentered 3 months after previous operations. & & \\
\hline 312 & 15 Nov 2005 & 2030 & 1255.1 & Trip in to 927 mbsf with coring Bit 1 (C9). & & 0.67 \\
\hline 312 & 15 Nov 2005 & 2330 & 1255.1 & $\begin{array}{l}\text { Wash and ream to } 944 \text { mbsf. Maximum penetration }=1051 \text { mbsf. The } 927-944 \mathrm{mbsf} \\
\text { interval seemed very tight. Generous mud flushes. }\end{array}$ & Reentry 25 , coring Bit 16 , tight hole at $927-944$ mbsf & 1.66 \\
\hline 312 & 17 Nov 2005 & 1525 & 1255.1 & On deck. & & \\
\hline 312 & 17 Nov 2005 & 2100 & 1255.1 & Trip in to $903 \mathrm{mbsf}$ with more aggressive tricone drilling bit (F-2 Smith tricone). & Reentry 26 , tricone, wash and ream & 2.64 \\
\hline 312 & 18 Nov 2005 & 0830 & 1255.1 & Wash and ream 903-1255 mbsf ( $40 \mathrm{~h})$. Bit stuck at $1198 \mathrm{mbsf}$ for $45 \mathrm{~min}$. & & \\
\hline 312 & 20 Nov 2005 & 0030 & 1255.1 & Trip out. & & \\
\hline 312 & 20 Nov 2005 & 0650 & 1255.1 & On deck. & & \\
\hline 312 & 20 Nov 2005 & 1215 & 1255.1 & Trip in to $1161 \mathrm{mbsf}$ with coring Bit 2 (C9). & Reentry 27 , coring Bit 17 & 1.02 \\
\hline 312 & 20 Nov 2005 & 2330 & 1255.1 & Wash and ream 1161-1255 mbsf. Debris in bit throat cleared by deplugger round trip. & & \\
\hline
\end{tabular}


Table T4 (continued). (Continued on next page).

\begin{tabular}{|c|c|c|c|c|c|c|}
\hline Leg & Date & Time & $\begin{array}{l}\text { Depth } \\
\text { (mbsf) }\end{array}$ & Comment & Brief run description & $\begin{array}{c}\text { Time } \\
\text { (days) }\end{array}$ \\
\hline 312 & 21 Nov 2005 & 0715 & 1255.1 & RCB coring 1255.1-1309.7 mbsf (Cores 172R-182R). & Cores $172 \mathrm{R}-182 \mathrm{R}$ & \\
\hline 312 & 24 Nov 2005 & 1015 & 1309.7 & $\begin{array}{l}\text { On deck (normal wear on cutting structures of the cones, } 3 / 16 \text { inch under gauge, core } \\
\text { guides extremely worn). }\end{array}$ & & \\
\hline 312 & 24 Nov 2005 & 1600 & 1309.7 & Trip in to 1205 mbsf with coring Bit 3 (C9). & Reentry 28 , coring Bit 18 & 0.61 \\
\hline 312 & 25 Nov 2005 & 0100 & 1309.7 & Wash and ream 1205-1310.1 mbsf. & & 0.19 \\
\hline 312 & 25 Nov 2005 & 0530 & 1309.7 & RCB coring 1310.1-1329.1 mbsf (Cores 183R-187R). & Cores 183R-187R & 1.44 \\
\hline 312 & 26 Nov 2005 & 1600 & 1329.1 & Round trip deplugger at 1329 mbsf. & & 0.06 \\
\hline 312 & 26 Nov 2005 & 1730 & 1329.1 & Resume coring 1329.1-1343.5 mbsf (Cores 188R-190R). & Cores 188R-190R & 1.35 \\
\hline 312 & 28 Nov 2005 & 0030 & 1345.5 & $\begin{array}{l}\text { On deck (similar to previous, } 10 \text { inserts missing from the gage row on } 1 \text { cone, chipped } \\
\text { teeth on nose region of all } 4 \text { cones). }\end{array}$ & & \\
\hline 312 & 28 Nov 2005 & 0600 & 1345.5 & Trip in to 1247 mbsf with coring Bit 4 (C9). & Reentry 29 , coring Bit 19 & 0.75 \\
\hline 312 & 28 Nov 2005 & 1830 & 1345.5 & Wash and ream 1247-1343.5 mbsf. & & 0.09 \\
\hline 312 & 28 Nov 2005 & 2045 & 1345.5 & RCB core 1343.5-1348.3 mbsf (Core 191R). & Core 191R & 0.41 \\
\hline 312 & 29 Nov 2005 & 0630 & 1348.3 & Repair standpipe flow sensor. & & 0.11 \\
\hline 312 & 29 Nov 2005 & 0830 & 1348.3 & Wash ahead 1299-1348 mbsf. & & \\
\hline 312 & 29 Nov 2005 & 0915 & 1345.5 & Resume coring 1348.3-1367.5 mbsf (Cores 192R-196R). & Cores 192R-196R & 1.88 \\
\hline 312 & 1 Dec 2005 & 0620 & 1367.5 & $\begin{array}{l}\text { On deck (less worn than previous bit, worked only } 40.2 \mathrm{~h} \text {. Few missing and chipped } \\
\text { inserts on the gauge row of the cones). }\end{array}$ & & \\
\hline 312 & 1 Dec 2005 & 1215 & 1367.5 & $\begin{array}{l}\text { Trip in to } 1285 \text { mbsf with coring Bit } 5 \text { (C7; it was hoped that a more aggressive cutting } \\
\text { structure would increase ROP and recovery). }\end{array}$ & Reentry 30 , coring Bit 20 & 0.82 \\
\hline 312 & 2 Dec 2005 & 0200 & 1367.5 & Wash and ream 1285-1367.5 mbsf. & & 0.07 \\
\hline 312 & 2 Dec 2005 & 0345 & 1367.5 & RCB coring 1367.5-1372.8 mbsf (Cores 197R-200R). Very slow average ROP $(0.3 \mathrm{~m} / \mathrm{h})$. & Cores 197R-200R & 1.22 \\
\hline 312 & 3 Dec 2005 & 0900 & 1372.8 & $\begin{array}{l}\text { Erratic high torque, unable to penetrate further (T/D stalled each time the bit was placed } \\
\text { on bottom). Trip out and clear seafloor. }\end{array}$ & Broken bit & 0.13 \\
\hline 312 & 3 Dec 2005 & 1200 & 1372.8 & On deck (Bit 20 was missing 3 cones and most of the fourth one). & & \\
\hline 312 & 3 Dec 2005 & 1745 & 1372.8 & Trip in to $1298.0 \mathrm{mbsf}$ with fishing magnet + junk baskets. & Reentry 31 , fishing & 0.99 \\
\hline 312 & 4 Dec 2005 & 0400 & 1372.8 & Wash to $1372.8 \mathrm{mbsf}$ and work junk baskets. & & \\
\hline 312 & 4 Dec 2005 & 0845 & 1372.8 & Trip out. & & \\
\hline 312 & 4 Dec 2005 & 1150 & 1372.8 & On deck (large fragments of cone and bearing material recovered from magnet face). & & \\
\hline 312 & 4 Dec 2005 & 1730 & 1372.8 & Trip to 1278.0 mbsf; wash to 1372.8 mbsf with 9.5 inch concave mill + 2 junk baskets. & Reentry 32, milling & 1.16 \\
\hline 312 & 5 Dec 2005 & 0630 & 1372.8 & Mill junk. & & \\
\hline 312 & 5 Dec 2005 & 1015 & 1372.8 & Flush hole with $50 \mathrm{bbl}$ high-vis mud sweep. & & \\
\hline 312 & 5 Dec 2005 & 1110 & 1372.8 & Mill junk. & & \\
\hline 312 & 5 Dec 2005 & 1230 & 1372.8 & Trip out. & & \\
\hline 312 & 5 Dec 2005 & 1545 & 1372.8 & On deck. & & \\
\hline 312 & 6 Dec 2005 & 0515 & 1372.8 & Trip to $1294.0 \mathrm{mbsf}$; wash to $1372.8 \mathrm{mbsf}$ with 9.5 inch concave mill + 1 junk basket. & Reentry 33, milling & 1.16 \\
\hline 312 & 6 Dec 2005 & 1015 & 1372.8 & Mill junk. & & \\
\hline 312 & 6 Dec 2005 & 1430 & 1372.8 & Flush hole with $50 \mathrm{bbl}$ high-vis mud sweep and trip out. & & \\
\hline 312 & 6 Dec 2005 & 1930 & 1372.8 & $\begin{array}{l}\text { On deck (milling tour worn, very small pieces of cone and bearing material in junk basket); } \\
\text { change to fishing magnet number } 2+2 \text { junk baskets. }\end{array}$ & & \\
\hline 312 & 7 Dec 2005 & 0200 & 1372.8 & Trip to 1295.0 mbsf with Bowen fishing magnet + 2 junk baskets. & Reentry 34 , fishing & 0.97 \\
\hline 312 & 7 Dec 2005 & 1300 & 1372.8 & Wash 1295-1372.8 mbsf. & & \\
\hline 312 & 7 Dec 2005 & 1430 & 1372.8 & Work magnet and junk baskets. & & \\
\hline 312 & 7 Dec 2005 & 1530 & 1372.8 & Trip out. & & \\
\hline 312 & 7 Dec 2005 & 1850 & 1372.8 & On deck (metal in magnet only fillings, with no solid fragments). & & \\
\hline 312 & 8 Dec 2005 & 0003 & 1372.8 & $\begin{array}{l}\text { Trip to } 1294 \mathrm{mbsf} \text { with RCB Bit } 6 \text { (C9), wash to } 1372.8 \mathrm{mbsf} \text {, core } 1372.8-1398.6 \mathrm{mbsf} \\
\text { (Cores 202R-209R). }\end{array}$ & Reentry 35 , coring Bit 21, Cores 202R-209R & 3.56 \\
\hline 312 & 11 Dec 2005 & 0820 & 1398.6 & On deck (Bit 6: uniform wear on the cones consistent with rotating hours). & & \\
\hline 312 & 11 Dec 2005 & 1545 & 1398.6 & $\begin{array}{l}\text { Trip to } 1326 \text { mbsf with RCB Bit } 7 \text { (C9), wash to } 1398.6 \mathrm{mbsf} \text {, core 1398.6-1444.6 mbsf } \\
\text { (Cores } 210 \mathrm{R}-221 \mathrm{R} \text { ). }\end{array}$ & $\begin{array}{l}\text { Reentry } 36 \text {, coring Bit } 22 \text {, Cores } 210 \mathrm{R}-221 \mathrm{R} \text {; dike/gabbro } \\
\text { boundary in Core } 213 \mathrm{R} \text {, on deck at } 0800 \mathrm{~h} \text { on } 13 \mathrm{Dec}\end{array}$ & 3.99 \\
\hline 312 & 15 Dec 2005 & 0810 & 1444.6 & On deck (Bit 8: uniform wear on the cones consistent with rotating hours). & 2005 & \\
\hline
\end{tabular}


Table T4 (continued). (Continued on next page).

\begin{tabular}{|c|c|c|c|c|c|c|}
\hline Leg & Date & Time & $\begin{array}{l}\text { Depth } \\
\text { (mbsf) }\end{array}$ & Comment & Brief run description & $\begin{array}{l}\text { Time } \\
\text { (days) }\end{array}$ \\
\hline 312 & 15 Dec 2005 & 1345 & 1444.6 & $\begin{array}{l}\text { Trip to } 1368 \text { mbsf with RCB Bit } 8 \text { (C9), wash to } 1444.6 \text { mbsf, core } 1444.6-1507.1 \text { mbsf } \\
\text { (Cores } 222 \mathrm{R}-234 \mathrm{R} \text {. }\end{array}$ & Reentry 37 , coring Bit 23 , Cores $222 \mathrm{R}-234 \mathrm{R}$ & 4.14 \\
\hline 312 & 19 Dec 2005 & 0300 & 1507.1 & Treat hole for logging and flush with mud. & & \\
\hline 312 & 19 Dec 2005 & 1135 & 1507.1 & RCB Bit 8 on deck; change to logging BHA. & & \\
\hline 312 & 19 Dec 2005 & 1715 & 1507.1 & Trip to $289 \mathrm{mbsf}$ and rig up for logging. & Reentry 38 , downhole measurements & 4.25 \\
\hline 312 & 23 Dec 2005 & 1200 & 1507.1 & End logging (triple combo, VSI, FMS-sonic, UBI, FMS, TAP/DLL/SGT). & & \\
\hline 312 & 23 Dec 2005 & 1730 & 1507.1 & Trip out and secure for voyage. & & \\
\hline 312 & & & & & Total: & 38.42 \\
\hline 335 & 19 Apr 2011 & 1730 & 1507.1 & Hole rentered 5.5 years after previous operations. & & \\
\hline 335 & 19 Apr 2011 & 1800 & 1507.1 & $\begin{array}{l}\text { Continue to RIH with } 5-1 / 2 \text { inch drill pipe to } 925.0 \text { mbsf, where formation took } 25,000 \mathrm{lb} \text {. } \\
\text { Cancel attempt to obtain temperature log and water sample. }\end{array}$ & $\begin{array}{l}\text { Reentry } 39 \text {, Run } 335-1 \text {, attempt to obtain temperature } \\
\text { profile and water sample }\end{array}$ & 0.02 \\
\hline 335 & 19 Apr 2011 & 2145 & 1507.1 & Pull back in the hole $925.0-891.9$ mbsf. & Obstruction at $\sim 925$ mbsf, washing and reaming & 1.91 \\
\hline 335 & 19 Apr 2011 & 2330 & 1507.1 & $\begin{array}{l}\text { Run in with T/D and work pipe at } 920-925 \mathrm{mbsf} \text {, where problems were encountered } \\
\text { during Expedition } 312 \text {. Erratic torque with T/D current }=500 \mathrm{~A} \text {. }\end{array}$ & & \\
\hline 335 & 20 Apr 2011 & 0115 & 1507.1 & Pull back $920-891.5$ mbsf and change out swivel packing. & & \\
\hline 335 & 20 Apr 2011 & 0245 & 1507.1 & $\begin{array}{l}\text { Resume washing/reaming } 891.5-923.3 \text { mbsf. Work stuck pipe from } 0415 \text { to } 0515 \mathrm{~h} \text {; } \\
\text { rotation lost. Unable to apply }>10,000 \mathrm{lb} \text { WOB without stalling T/D. Circulate a total of } \\
600 \text { bbl of hi-vis gel during the } 24 \mathrm{~h} \text { period. Unable to penetrate deeper than } 923.3 \\
\text { mbsf. Pump } 150 \text { bbl sweep at } 923.3 \text { mbsf. }\end{array}$ & & \\
\hline 335 & 21 Apr 2011 & 0600 & 1507.1 & $\mathrm{POOH}$ from $923.3 \mathrm{mbsf}$. Bit clears rotary at $1550 \mathrm{~h}$. & & \\
\hline 335 & 21 Apr 2011 & 1545 & 1507.1 & $\begin{array}{l}\text { Make up new Reed 9-7/8 inch tricone (more aggressive structure), bit sub with float valve, } \\
\text { and tandem set of boot baskets. RIH with the drill pipe to } 892.1 \text { mbsf. }\end{array}$ & $\begin{array}{l}\text { Reentry } 40, \text { Run } 335-2 \text {, tricone }+2 \text { junk baskets, washing } \\
\text { and reaming }\end{array}$ & 1.64 \\
\hline 335 & 22 Apr 2011 & 0445 & 1507.1 & Wash/ream hole from 892.1 to bridge at $~ 920$ mbsf. Pump 50 bbl hi-vis mud sweep. & & \\
\hline 335 & 22 Apr 2011 & 0630 & 1507.1 & Work stuck pipe. & & \\
\hline 335 & 22 Apr 2011 & 0745 & 1507.1 & Wash/ream hole from 920 mbsf. Circulate $100 \mathrm{bbl} \mathrm{hi-vis} \mathrm{mud} \mathrm{sweep.}$ & & \\
\hline 335 & 22 Apr 2011 & 1000 & 1507.1 & Work stuck pipe. & & \\
\hline 335 & 22 Apr 2011 & 1200 & 1507.1 & Wash/ream hole from 923 mbsf. Unable to pass bridge. & & \\
\hline 335 & 22 Apr 2011 & 2100 & 1507.1 & $\begin{array}{l}\text { POOH, clear seafloor at } 0005 \mathrm{~h} \text { and rotary table at } 0605 \mathrm{~h} \text {. Lay out junk baskets and bit. } \\
\text { Contents of junk baskets inconclusive; yielded some basaltic cuttings ranging from small } \\
\text { gravel to rounded pebbles. Expedition } 312 \text { logs indicate a large washed out zone at } \\
\sim 920-935 \text { mbsf; decision to attempt to stabilize with a } 5 \text { bbl cement plug. }\end{array}$ & & \\
\hline 335 & 23 Apr 2011 & 0700 & 1507.1 & $\begin{array}{l}\text { Make up cementing BHA with used Reed tricone bit without jets and } 2 \text { stands of drill } \\
\text { collars. RIH to bridge at } 922 \text { mbsf. }\end{array}$ & Reentry 41 , Run $335-3$, cementing ( 5 bbl) & 0.93 \\
\hline 335 & 23 Apr 2011 & 1845 & 1507.1 & Make up circulating head, lo-torque valves, and pressure test to $1500 \mathrm{psi}$. & & \\
\hline 335 & 23 Apr 2011 & 1915 & 1507.1 & Pump 5 bbl of 16 ppg cement slurry. & & \\
\hline 335 & 23 Apr 2011 & 1930 & 1507.1 & Displace drill string with seawater $(1 \times$ volume $)$. & & \\
\hline 335 & 23 Apr 2011 & 2000 & 1507.1 & Lay out circulating head and pull back in the hole with the drill string to $806.9 \mathrm{mbsf}$. & & \\
\hline 335 & 23 Apr 2011 & 2030 & 1507.1 & Flush drill string with seawater ( $3 \times$ volume). & & \\
\hline 335 & 23 Apr 2011 & 2145 & 1507.1 & Lay out circulating head and $\mathrm{POOH}$. Bit at rotary table at $0515 \mathrm{~h}$. & & \\
\hline 335 & 24 Apr 2011 & 0515 & 1507.1 & $\begin{array}{l}\text { Make up new } 9-7 / 8 \text { inch Atlas tricone bit, inspect float, pick up } 2 \text { drill collar stands from } \\
\text { derrick. Trip drill string to } 922 \text { mbsf. }\end{array}$ & Reentry 42 , Run 335-4, tricone, washing and reaming & 1.04 \\
\hline 335 & 24 Apr 2011 & 1930 & 1507.1 & Pull back in the hole to $890.6 \mathrm{mbsf}$, run in hole with T/D to $922 \mathrm{mbsf}$. & & \\
\hline 335 & 24 Apr 2011 & 2045 & 1507.1 & Attempt to wash/ream though bridge; high erratic torque; maximum T/D =650 A. & & \\
\hline 335 & 24 Apr 2011 & 2145 & 1507.1 & Pull back with T/D to $890.6 \mathrm{mbsf}$, POOH. Bit at rotary table at $0615 \mathrm{~h}$. & & \\
\hline 335 & 25 Apr 2011 & 0615 & 1507.1 & Make up cementing bit (Reed 517; no nozzles) to 2 stands of drill collars, RIH to 922 mbsf. & Reentry 43, Run 335-5, cementing (50 bbl) & 0.90 \\
\hline 335 & 25 Apr 2011 & 1715 & 1507.1 & Install circulating head. Pressure test cement system. & & \\
\hline 335 & 25 Apr 2011 & 1800 & 1507.1 & Mix and pump $50 \mathrm{bbl}$ of $15 \mathrm{ppg}$ cement slurry. & & \\
\hline 335 & 25 Apr 2011 & 1845 & 1507.1 & Displace cement slurry with seawater. & & \\
\hline 335 & 25 Apr 2011 & 1900 & 1507.1 & Lay out circulating head and pull back in the hole to 720.5 mbsf. & & \\
\hline 335 & 25 Apr 2011 & 1945 & 1507.1 & Circulate and flush drill pipe with seawater ( $3 \times$ volume). & & \\
\hline 335 & 25 Apr 2011 & 2045 & 1507.1 & $\mathrm{POOH}$ with the drill string to surface. Bit at rotary table at $0345 \mathrm{~h}$. & & \\
\hline
\end{tabular}


Table T4 (continued). (Continued on next page).

\begin{tabular}{|c|c|c|c|c|c|c|}
\hline Leg & Date & Time & $\begin{array}{l}\text { Depth } \\
\text { (mbsf) }\end{array}$ & Comment & Brief run description & $\begin{array}{l}\text { Time } \\
\text { (days) }\end{array}$ \\
\hline 335 & 26 Apr 2011 & 0345 & 1507.1 & $\begin{array}{l}\text { Pick up 9-7/8 inch Atlas HP61 tricone with tandem boot baskets and } 2 \text { stands of drill } \\
\text { collars. Run in hole to firm contact with cement at } 882.0 \text { mbsf. }\end{array}$ & $\begin{array}{l}\text { Reentry } 44 \text {, Run 335-6, drilling cement, washing and } \\
\text { reaming }\end{array}$ & 2.47 \\
\hline 335 & 26 Apr 2011 & 1815 & 1507.1 & Drill out cement with T/D 882.0-922.0 mbsf. Circulate $40 \mathrm{bbl}$ gel sweep at 904.6 mbsf. & & \\
\hline 335 & 26 Apr 2011 & 2230 & 1507.1 & $\begin{array}{l}\text { Attempt to drill through bridge with high erratic torque. Circulate } 50 \mathrm{bbl} \text { gel sweep at } 922 \\
\text { mbsf. Continue to wash/ream at } 922.0 \mathrm{mbsf} \text {. Maximum T/D }=650 \mathrm{~A} \text {. }\end{array}$ & & \\
\hline 335 & 27 Apr 2011 & 0130 & 1507.1 & Work stuck pipe at $\sim 923$ mbsf. Maximum T/D = 800 A with $120,000 \mathrm{lb}$ overpull. & & \\
\hline 335 & 27 Apr 2011 & 0230 & 1507.1 & $\begin{array}{l}\text { Resume washing/reaming ledge at } 922 \mathrm{mbsf} \text { with high rotary speed, high pump, and } \\
\text { lighter WOB. mid-morning progress was lost later in the day, which may indicate a } \\
\text { shifting obstruction. Circulate multiple } 50 \text { bbl hi-vis gel sweeps at } 922 \text { mbsf. Continue to } \\
\text { wash/ream obstruction at } 921.6 \text { mbsf (tide } \pm 0.5 \text { m). Circulate } 100 \text { bbl hi-vis gel sweep } \\
\text { at } 922.0 \text { mbsf. }\end{array}$ & & \\
\hline 335 & 28 Apr 2011 & 0600 & 1507.1 & $\begin{array}{l}\mathrm{POOH} \text {, clear seafloor at } 0850 \mathrm{~h} \text { and bit at rotary table at } 1455 \mathrm{~h} \text {. Bit in good condition } \\
\text { with no appreciable shirttail wear, all teeth intact, and exhibiting very little wear. }\end{array}$ & & \\
\hline 335 & 28 Apr 2011 & 1500 & 1507.1 & $\begin{array}{l}\text { Make up new Smith tricone bit, bit sub with float, and } 4 \text { stands of drill collars; RIH with } \\
\text { drill string to } 861.4 \text { mbsf. RIH with T/D 861.4-921.9 mbsf. }\end{array}$ & $\begin{array}{l}\text { Reentry } 45 \text {, Run } 335-7 \text {, washing and reaming, reached } \\
\text { bottom }\end{array}$ & 3.49 \\
\hline 335 & 29 Apr 2011 & 0615 & 1507.1 & $\begin{array}{l}\text { Attempt to pass obstruction with pump and no rotation. No advance. Resume washing/ } \\
\text { reaming, drill through obstruction at } 935.0 \text { mbsf, and advance } 921.9-941.5 \mathrm{mbsf} \text {. } \\
\text { Circulate } 100 \text { bbl gel sweep at } 931.0 \mathrm{mbsf} \text {. }\end{array}$ & & \\
\hline 335 & 30 Apr 2011 & 0000 & 1507.1 & $\begin{array}{l}\text { Continue to wash/ream } 941.5-1143.2 \mathrm{mbsf} \text {. High torque and pump pressure increase of } \\
500 \text { psi when picking off slips at last connection. Circulate } 50 \mathrm{bbl} \text { hi-vis gel sweeps at } \\
988.6 \text { and } 1113.6 \mathrm{mbsf} \text {. Work back to } 1114.4 \mathrm{mbsf} \text { and work out excess pump pressure } \\
\text { and torque. }\end{array}$ & & \\
\hline 335 & 30 Apr 2011 & 1400 & 1507.1 & $\begin{array}{l}\text { Resume washing/reaming } 1143.2-1162.4 \text { mbsf. High torque and increase of } 500 \text { psi } \\
\text { pump pressure when coming off slips on last connection. }\end{array}$ & & \\
\hline 335 & 30 Apr 2011 & 1630 & 1507.1 & Work stuck pipe free. & & \\
\hline 335 & 30 Apr 2011 & 1830 & 1507.1 & $\begin{array}{l}\text { Wash/ream } 1162.4-1507.1 \text { mbsf. Circulate } 50 \mathrm{bbl} \text { hi-vis gel sweeps at } 1142.6 \text { and } 1253.6 \\
\text { mbsf. Find } 6 \mathrm{~m} \text { of hard fill. Circulate } 100 \mathrm{bbl} \mathrm{hi-vis} \mathrm{gel} \mathrm{sweep.}\end{array}$ & & \\
\hline 335 & 1 May 2011 & 1030 & 1507.1 & Pull back in the hole with T/D 1507.1-1265.0 mbsf. & & \\
\hline 335 & 1 May 2011 & 1245 & 1507.1 & Pull back in the hole with drill string $1265.0-890.5$ mbsf. & & \\
\hline 335 & 1 May 2011 & 1530 & 1507.1 & RIH with drill string and T/D to 967.3 mbsf with no drag or overpull. & & \\
\hline 335 & 1 May 2011 & 1630 & 1507.1 & $\begin{array}{l}\text { Break circulation; spot } 60 \mathrm{bbl} \text { of } 10.5 \mathrm{ppg} \text { mud at } 967 \mathrm{mbsf} . \mathrm{POOH} \text {; bit at rotary table at } \\
0245 \mathrm{~h} \text {. }\end{array}$ & & \\
\hline 335 & 2 May 2011 & 0245 & 1507.1 & Make up cement BHA with used Reed 9-7/8 inch bit (without jets) and RIH to 960.5 mbsf. & Reentry 46 , Run $335-8$, cementing & 1.02 \\
\hline 335 & 2 May 2011 & 1615 & 1507.1 & $\begin{array}{l}\text { Make up circulating head and pressure test to } 2000 \text { psi; mix and pump } 60 \mathrm{bbl} \text { of } 15 \mathrm{ppg} \\
\text { cement slurry. }\end{array}$ & & \\
\hline 335 & 2 May 2011 & 1715 & 1507.1 & Displace cement with seawater. & & \\
\hline 335 & 2 May 2011 & 1745 & 1507.1 & Lay out circulating head and pull back in the hole to $605.5 \mathrm{mbsf}$. & & \\
\hline 335 & 2 May 2011 & 1845 & 1507.1 & Flush drill string with seawater ( $3 \times$ volume $)$. & & \\
\hline 335 & 2 May 2011 & 1945 & 1507.1 & $\mathrm{POOH}$ with the drill string. Bit at rotary table at $0315 \mathrm{~h}$. & & \\
\hline 335 & 3 May 2011 & 0315 & 1507.1 & $\begin{array}{l}\text { Lay out Reed tricone bit and pick up RCB assembly (coring Bit 1), RIH to tag contact (ledge } \\
\text { or top of plug) at } 924.0 \text { mbsf. }\end{array}$ & $\begin{array}{l}\text { Reentry 47, Run 335-9, coring Bit } 24 \text { (first of Expedition } \\
335 \text { ), cement coring (no recovery) }\end{array}$ & 1.85 \\
\hline 335 & 3 May 2011 & 1500 & 1507.1 & Pull back in the hole $924.0-891.5$ mbsf, pick up T/D. & & \\
\hline 335 & 3 May 2011 & 1600 & 1507.1 & Drop nonmagnetic core barrels. Establish SCR parameters. & & \\
\hline 335 & 3 May 2011 & 1745 & 1507.1 & Cut cement cores $924.0-971.3 \mathrm{mbsf}$ (Cores 1G-5G: no recovery). & & \\
\hline 335 & 4 May 2011 & 0600 & 1507.1 & Pull back in the hole to 833.9 mbsf. & & \\
\hline 335 & 4 May 2011 & 0845 & 1507.1 & Drop wash barrel, RIH 833.9-971.3 mbsf. & & \\
\hline 335 & 4 May 2011 & 1030 & 1507.1 & Round trip wash barrel and core $971.3-980.9 \mathrm{mbsf}$ (Core 6G). & & \\
\hline 335 & 4 May 2011 & 1330 & 1507.1 & $\begin{array}{l}\text { Drop wash barrel and wash } 980.9-1507.1 \text { mbsf. Note tight hole at } 1499.6-1501.1 \mathrm{mbsf} \text {. } \\
\text { Pump 50-bbl hi-vis sweeps at } 1154.6 \text { and } 1501.1 \mathrm{mbsf}\end{array}$ & & \\
\hline 335 & 4 May 2011 & 2245 & 1507.1 & Circulate 50 -bbl hi-vis gel sweep. & & \\
\hline 335 & 4 May 2011 & 2345 & 1507.1 & Deploy sinker bars. Round trip wash barrel at 1497.0 mbsf. Drop fresh core barrel. & Cores $235 \mathrm{R}-236 \mathrm{R}$ (total $94 \mathrm{~cm}$, undergauge pieces) & 0.72 \\
\hline 335 & 5 May 2011 & 0145 & 1507.1 & $\begin{array}{l}\text { RCB core } 1507.1-1516.5 \text { mbsf (Cores } 235 \mathrm{R}-236 \mathrm{R} \text { ), using half-cores with no liners to } \\
\text { improve recovery. All cores obtained with nonmagnetic core barrels. }\end{array}$ & & \\
\hline
\end{tabular}


Table T4 (continued). (Continued on next page).

\begin{tabular}{|c|c|c|c|c|c|c|}
\hline Leg & Date & Time & $\begin{array}{l}\text { Depth } \\
\text { (mbsf) }\end{array}$ & Comment & Brief run description & $\begin{array}{l}\text { Time } \\
\text { (days) }\end{array}$ \\
\hline 335 & 5 May 2011 & 1700 & 1516.5 & $\begin{array}{l}\text { Attempt to core } 1516.5-1518.2 \text { mbsf (Core } 237 \mathrm{R} \text { ) with maximum overpull }=60,000 \mathrm{lb} \text {, } \\
\text { maximum T/D }=800 \mathrm{~A}, \text { WOB }=0 \text {. Circulate } 50 \text { and } 100 \mathrm{bbl} \text { hi-vis gel sweeps at } 1518.2 \\
\text { mbsf after retrieving Core } 237 \mathrm{R} \text {. }\end{array}$ & Core $237 \mathrm{R}$ & 1.53 \\
\hline 335 & 5 May 2011 & 2145 & 1520.2 & $\begin{array}{l}\text { Drop core barrel and attempt to core } 1518.2-1520.2 \mathrm{mbsf} \text { (Core } 238 \mathrm{R} \text {; tide } \pm 0.8 \mathrm{~m} \text { ). } \\
\text { Pump 50-bbl hi-vis sweep at } 1520.2 \mathrm{mbsf} \text {. Average ROP for } 5 \text { May was } 0.7 \mathrm{~m} / \mathrm{h} .3 \mathrm{~cm} \times \\
20 \mathrm{~cm} \text { rollers. }\end{array}$ & Core $238 \mathrm{R}$ ( 3 rollers) & \\
\hline 335 & 6 May 2011 & 1330 & 1520.2 & $\begin{array}{l}\text { Drop bit deplugger. Examine core catcher sub: } 0.5 \text { inch abraded away, indicating } \\
\text { downhole mechanical problem. Recover deplugger. Pump } 70 \mathrm{bbl} \text { of } 10.5 \text { ppg mud. }\end{array}$ & & \\
\hline 335 & 6 May 2011 & 1645 & 1520.2 & Pull back in hole with drill string to $58.2 \mathrm{mbsf}$, flush with seawater to clean reentry cone. & & \\
\hline 335 & 6 May 2011 & 2100 & 1520.2 & $\begin{array}{l}\text { POOH. Clear the rotary at } 0545 \mathrm{~h} \text {. Bit body honed to a smooth profile at the bottom and } \\
\text { on the sides. Bit missing all } 4 \text { cones, } 4 \text { legs, and core guides. Bit spiral stabilizer blades } \\
\text { and embedded TCl inserts absent. Bit totally unrecognizable. }\end{array}$ & Disintegrated coring bit! & \\
\hline 335 & 7 May 2011 & 0545 & 1520.2 & $\begin{array}{l}\text { Prepare and make up Bowen } 9 \text { inch fishing magnet with } 2 \text { boot baskets to } 2 \text { stands of drill } \\
\text { collars and RIH to } 3632 \text { mbrf. }\end{array}$ & Reentry 48 , Run $335-10$, fishing (magnet +2 junk baskets) & 1.43 \\
\hline 335 & 7 May 2011 & 1630 & 1520.2 & $\begin{array}{l}\text { Search and position vessel for reentry. Observe reentry cone clouded over with mud. } \\
\text { Attempt reentry, miss cone, and pull back. Break circulation and reenter at } 1815 \mathrm{~h} \text {. }\end{array}$ & & \\
\hline 335 & 7 May 2011 & 1815 & 1520.2 & RIH with drill string to $1294.6 \mathrm{mbsf}$. Contact ledge that takes $10,000 \mathrm{lb}$. & & \\
\hline 335 & 7 May 2011 & 2245 & 1520.2 & $\begin{array}{l}\text { RIH with T/D to } 1434.2 \text { mbsf. Tight hole at } 1328.7 \mathrm{mbsf} \text { takes } 10,000 \mathrm{lb} \text {. Excessive rotary } \\
\text { current at } 20 \mathrm{spm} \text {. Increase in pump pressure ( } 2500 \mathrm{psi} \text { at } 20 \mathrm{spm}) \text {. Bleed off pressure at } \\
\text { rig floor. }\end{array}$ & & \\
\hline 335 & 8 May 2011 & 0145 & 1520.2 & $\begin{array}{l}\text { Pull back in the hole 1434.2-1395.8 mbsf; attempt to unplug drill string with high } \\
\text { pressure. No joy. }\end{array}$ & & \\
\hline 335 & 8 May 2011 & 0300 & 1520.2 & $\begin{array}{l}\text { POOH to } 264.2 \text { mbsf just inside casing shoe; attempt to circulate with circulating head. } \\
\text { No loy. }\end{array}$ & & \\
\hline 335 & 8 May 2011 & 0715 & 1520.2 & $\begin{array}{l}\text { POOH from } 264.2 \mathrm{mbsf} \text { and clear seafloor at } 0755 \mathrm{hr} .4 \mathrm{~m} \text { of fine cuttings plugging inside } \\
\text { bit sub and } 2 \text { junk baskets. Magnet at the rotary table at } 1555 \mathrm{~h} \text {. }\end{array}$ & & \\
\hline 335 & 8 May 2011 & 1600 & 1520.2 & $\begin{array}{l}\text { Make up Atlas tricone bit to dual set of junk baskets with } 3 \text { drill collar stands and deploy to } \\
1356.1 \mathrm{mbsf} \text {, where bit contacts ledge. Pull back to } 1324.3 \mathrm{mbsf} \text {. }\end{array}$ & Reentry 49 , Run $335-11$, tricone +2 junk baskets & 1.84 \\
\hline 335 & 9 May 2011 & 0715 & 1520.2 & $\begin{array}{l}\text { Pickup T/D and obtain SCR parameters. Clean up ledge at } 1356.1 \mathrm{mbsf} \text { and continue in } \\
\text { the hole to } 1442.5 \mathrm{mbsf} \text {. Circulate } 100 \mathrm{bbl} \mathrm{hi-vis} \mathrm{gel} \mathrm{sweep} \mathrm{at} 1442.5 \mathrm{mbsf} \text {. }\end{array}$ & & \\
\hline 335 & 9 May 2011 & 1000 & 1520.2 & $\begin{array}{l}\text { RIH 1442.5-1520.3 mbsf. Clean up undergage areas of hole: maximum T/D }=500 \mathrm{~A} \text {. } \\
\text { Circulate } 100 \text { bbl hi-vis gel sweep at } 1520.3 \text { mbsf. Continue to circulate, work rathole at } \\
1520.3 \text { mbsf. Circulate } 100 \text { bbl hi-vis gel sweep and circulate seawater }(3 \times \text { volume). }\end{array}$ & & \\
\hline 335 & 9 May 2011 & 1615 & 1520.2 & $\begin{array}{l}\text { Pull back in the hole with T/D } 1520.3-1363.0 \text { mbsf. RIH and tag ledge at } 1473 \text { mbsf. } \\
\text { Work through ledge with pumps and rotation. Observe excess pump pressure and } \\
\text { torque off slips at } 1477.5 \text { mbsf. Unable to pump. Reestablish rotation and circulation. }\end{array}$ & & \\
\hline 335 & 9 May 2011 & 1930 & 1520.2 & $\begin{array}{l}\text { Work pipe from } 1477.5 \text { back to } 1459.0 \text { mbsf. Clear excess pump pressure and torque. } \\
\text { Maximum } \mathrm{T} / \mathrm{D}=700 \mathrm{~A} \text {, maximum pump pressure }=3000 \mathrm{psi} \text {. }\end{array}$ & & \\
\hline 335 & 9 May 2011 & 2015 & 1520.2 & Ream 1477.6-1484.6 mbsf. Continue with T/D to $1518.2 \mathrm{mbsf}$, pump $150 \mathrm{bbl}$ gel sweep. & & \\
\hline 335 & 10 May 2011 & 1130 & 1520.2 & $\mathrm{POOH}$. Flush top of cone with seawater. Bit at rotary at $1130 \mathrm{~h}$. Empty junk baskets. & & \\
\hline 335 & 10 May 2011 & 1215 & 1520.2 & $\begin{array}{l}\text { Make up Bowen RCJB, } 1 \text { junk basket, and } 2 \text { stands of drill collars. RIH to } 1327.5 \text { mbsf; RIH } \\
\text { with T/D to } 1517.9 \text { mbsf. }\end{array}$ & Reentry 50, Run 335-12, RCJB + EXJB & 1.74 \\
\hline 335 & 11 May 2011 & 0630 & 1520.2 & $\begin{array}{l}\text { Clean hole. Circulate at } 150 \mathrm{spm} \text { with } 1600 \mathrm{psi} \text {. Find } 2.5 \mathrm{~m} \text { of fill. Pump } 100 \mathrm{bbl} \text { hi-vis } \\
\text { sweep and chase with seawater }(1.5 \times \text { volume }) \text {. }\end{array}$ & & \\
\hline 335 & 11 May 2011 & 0930 & 1520.2 & Drop stainless steel ball at $0937 \mathrm{~h}$ and activate reverse circulation in Bowen junk basket. & & \\
\hline 335 & 11 May 2011 & 1000 & 1520.2 & Attempt to drill over junk at the bottom of the hole. & & \\
\hline 335 & 11 May 2011 & 1030 & 1520.2 & $\begin{array}{l}\text { POOH. Clear top of cone at } 1520 \mathrm{~h} \text {. BHA drill collars up to T/D filled with fine cuttings ( } 50 \\
\mathrm{~m} \text {, several hundred } \mathrm{kg} \text { ). Coarser gravel found in the head, crossover, and bit subs. } 20 \\
\mathrm{~kg} \text { of granoblastic dike rocks in Bowen RCJB. }\end{array}$ & & \\
\hline
\end{tabular}


Table T4 (continued). (Continued on next page).

\begin{tabular}{|c|c|c|c|c|c|c|}
\hline Leg & Date & Time & $\begin{array}{l}\text { Depth } \\
\text { (mbsf) }\end{array}$ & Comment & Brief run description & $\begin{array}{l}\text { Time } \\
\text { (days) }\end{array}$ \\
\hline 335 & 12 May 2011 & 0600 & 1520.2 & Make up Bowen tool with 1 junk basket and 2 stands of drill collars; RIH to 1384.8 mbsf. & Reentry 51, Run 335-13, RCJB + EXJB & 1.28 \\
\hline 335 & 12 May 2011 & 1730 & 1520.2 & $\begin{array}{l}\text { RIH with T/D and rotation and circulation past a soft tag at } 1465.0 \text { mbsf and a hard tag at } \\
1518.0 \text { mbsf. Backflow on connections starting at } 1470.0 \text { mbsf. }\end{array}$ & & \\
\hline 335 & 12 May 2011 & 2015 & 1520.2 & $\begin{array}{l}\text { Work drill string to } 1518.0 \mathrm{mbsf} \text { and fail in an attempt to penetrate to } 1520.2 \mathrm{mbsf} \text { with } \\
\text { maximum WOB }=2000-4000 \mathrm{lb} \text {, and } 160 \mathrm{spm} \text { at } 1600 \mathrm{psi} \text { Maximum T/D }=200-400 \\
\text { A. Circulate } 100 \mathrm{bbl} \text { hi-vis sweep, and chase with seawater }(2 \times \text { volume). }\end{array}$ & & \\
\hline 335 & 12 May 2011 & 2215 & 1520.2 & $\begin{array}{l}\text { Drop stainless ball to activate reverse circulation. Apparently unable to shear pins in tool } \\
\text { with pump pressure up to } 3000 \text { psi at } 50 \mathrm{spm} \text {. }\end{array}$ & & \\
\hline 335 & 12 May 2011 & 2300 & 1520.2 & $\begin{array}{l}\text { POOH, clear seafloor at } 0340 \mathrm{~h} \text {. Bowen RCJB at rotary table at } 1100 \mathrm{~h} \text { : contains large } \\
\text { granoblastic dike rocks (up to } 4.5 \mathrm{~kg} \text { ). RCJB was activated by the stainless ball. Loss of } \\
\text { circulation probably due to clogged jets. Almost entire BHA filled with fine cuttings. }\end{array}$ & & \\
\hline 335 & 13 May 2011 & 1245 & 1520.2 & $\begin{array}{l}\text { Pick up Homco } 9-3 / 4 \text { inch FTJB with bit sub junk basket and float, } 2 \text {-stand BHA, and boot } \\
\text { basket. RIH to } 1517.2 \text { mbsf. Pump } 100 \text { bbl sweep and continue to work down to top of } \\
\text { fish at } 1521.0 \text { mbsf. }\end{array}$ & Reentry 52, Run 335-14, FTJB + BSJB & 1.34 \\
\hline 335 & 14 May 2011 & 0815 & 1520.2 & Attempt to recover junk/fish. Circulate $50 \mathrm{bbl} \mathrm{sweep} \mathrm{at} 1520.0$ mbsf. & & \\
\hline 335 & 14 May 2011 & 0945 & 1520.2 & $\begin{array}{l}\text { POOH. Rack back drill collars. HOMCO FTJB clears rotary at } 2010 \mathrm{~h} \text {. Empty FTJB of } 2 \text { rocks } \\
\text { (combined weight }=3.2 \mathrm{~kg} \text { ). Lower set of junk catcher fingers completely torn out. }\end{array}$ & & \\
\hline 335 & 14 May 2011 & 2100 & 1520.2 & $\begin{array}{l}\text { Make up new Smith hard formation 9-7/8 inch tricone bit with } 1 \text { junk basket to 3-stand } \\
\text { BHA and RIH to } 1371.8 \text { mbsf. }\end{array}$ & Reentry 53, Run 335-15, tricone + junk basket & 1.80 \\
\hline 335 & 15 May 2011 & 1245 & 1520.2 & $\begin{array}{l}\text { Resume RIH with T/D from } 1371.8 \mathrm{mbsf} \text {. Tag soft fill at } 1510.0 \mathrm{mbsf} \text { and hard tag at } \\
1518.8 \mathrm{mbsf} \text {. }\end{array}$ & & \\
\hline 335 & 15 May 2011 & 1415 & 1520.2 & $\begin{array}{l}\text { Pick up } 30 \mathrm{ft} \text { knobby and work bit with light WOB at } 1518.5 \mathrm{mbsf} \text { and then to } 1520.6 \\
\text { mbsf multiple times, attempting to stabilize bottom } 2-3 \mathrm{~m} \text { of the hole. Hole seems to } \\
\text { pack off below } 1518.0 \mathrm{mbsf} \text { and requires working back to bottom. Circulate multiple } \\
\text { mud sweeps at } 1520.6 \mathrm{mbsf} \text { (total }=400 \text { bbl). Continue to work drill string } 1518.5- \\
1521.05 \text { mbsf. Pump } 200 \text { bbl of sweeps. Pull drill string to inspect and change bit. }\end{array}$ & & \\
\hline 335 & 16 May 2011 & 0615 & 1520.2 & $\begin{array}{l}\text { POOH, clear the seafloor at } 1015 \mathrm{~h} \text {. Bit clears rotary at } 1545 \mathrm{~h} \text {. Inspect bit and find } \\
\text { bearings still tight with virtually no wear on teeth except for a single chipped tooth on } \\
\text { the heel. The bit is undergage by } 0.4 \text { inch with some shirttail wear and minor junk } \\
\text { damage on the body. }\end{array}$ & & \\
\hline 335 & 16 May 2011 & 1615 & 1520.2 & $\begin{array}{l}\text { Make up new 9-7/8 inch Smith FH3VPS tricone to a 3-stand BHA and RIH to } 1399.7 \text { mbsf, } \\
\text { and to } 1516.5 \text { with T/D. }\end{array}$ & Reentry 54, Run 335-16, tricone bit & 1.76 \\
\hline 335 & 17 May 2011 & 0815 & 1520.2 & $\begin{array}{l}\text { Wash/ream } 1516.5-1519.7 \text { mbsf. Circulate } 60 \mathrm{bbl} \text { sweep at } 1516.7 \mathrm{mbsf} \text {. Flush hole with } \\
200 \mathrm{bbl} \text { of mud at } 1519.6 \mathrm{mbsf} \text {. }\end{array}$ & & \\
\hline 335 & 18 May 2011 & 0100 & 1520.2 & $\begin{array}{l}\text { POOH. Clear seafloor at } 0340 \mathrm{~h} \text {. Bit at rotary table at } 0900 \mathrm{~h} \text {. Tricone bit in gauge, minus } \\
6 \text { teeth on one cone. }\end{array}$ & & \\
\hline 335 & 18 May 2011 & 1030 & 1520.2 & $\begin{array}{l}\text { Make up 9-5/8 inch flat-bottomed mill with EXJB and 3-stand BHA; RIH to } 1429.9 \text { mbrf. } \\
\text { Continue to RIH with the T/D 1429.9-1520.0 mbsf. }\end{array}$ & Reentry 55, Run 335-17, milling tool & 1.70 \\
\hline 335 & 19 May 2011 & 0130 & 1520.2 & $\begin{array}{l}\text { Mill debris at } 1520.0-1521.0 \text { mbsf. Use junk basket pump sweeps. Pump } 200 \text { bbl sweep } \\
\text { at } 1520.0 \text { mbsf. }\end{array}$ & & \\
\hline 335 & 19 May 2011 & 1330 & 1520.2 & Circulate $100 \mathrm{bbl}$ sweep and chase same with seawater ( $2 \times$ volume). & & \\
\hline 335 & 19 May 2011 & 1445 & 1520.2 & $\begin{array}{l}\text { POOH, clear seafloor at } 1920 \mathrm{~h} \text {. Used mill at rotary table at } 0315 \mathrm{~h} \text {. Clean and lay out } \\
\text { damaged junk basket. Mill heavily worn and undergage by } \sim 0.5 \text { inch. }\end{array}$ & & \\
\hline 335 & 20 May 2011 & 0315 & 1520.2 & Pick up new 9 inch flat mill with fresh junk basket and RIH to 1458.6 mbsf. & Reentry 56, Run 335-18, milling tool & 1.40 \\
\hline 335 & 20 May 2011 & 1845 & 1520.2 & $\begin{array}{l}\text { RIH with T/D and tag fill at } 1518.9 \text { mbsf. Advance with low pump and rotary speed and } \\
\text { tag hard fill at } 1520.4 \text { mbsf. }\end{array}$ & & \\
\hline 335 & 20 May 2011 & 1945 & 1520.2 & Mill junk and work junk basket. Pump several sepiolite sweeps and circulate out. & & \\
\hline 335 & 21 May 2011 & 0300 & 1520.2 & $\begin{array}{l}\mathrm{POOH} \text {, clear the seafloor at } 0645 \mathrm{~h} \text {; milling tool at the drill floor at } 1225 \mathrm{~h} \text {. Abrasive } \\
\text { surface of the milling tool eroded away; some external junk damage on the side of the } \\
\text { tool and the crossover sub directly above the mill. In addition to the usual rock } \\
\text { fragments and fine cuttings, some flakes of what appears to be freshly ground metal. }\end{array}$ & & \\
\hline
\end{tabular}


Table T4 (continued). (Continued on next page).

\begin{tabular}{|c|c|c|c|c|c|c|}
\hline Leg & Date & Time & $\begin{array}{l}\text { Depth } \\
\text { (mbsf) }\end{array}$ & Comment & Brief run description & $\begin{array}{l}\text { Time } \\
\text { (days) }\end{array}$ \\
\hline 335 & 21 May 2011 & 1245 & 1520.2 & $\begin{array}{l}\text { Make up RCJB with } 3 \text { EXJBs and deploy along with a 2-stand BHA. RIH to } 1405.7 \text { mbsf } \\
\text { with drill pipe, and then to } 1519.5 \text { mbsf. Hard tag at } 1519.5 \text { mbsf. }\end{array}$ & Reentry $57, \mathrm{RCJB}+3$ EXJB & 1.22 \\
\hline 335 & 22 May 2011 & 0315 & 1520.2 & Work junk baskets. Pump 100 bbl sweep and chase with seawater ( 2 × volume). & & \\
\hline 335 & 22 May 2011 & 0545 & 1520.2 & $\begin{array}{l}\text { Drop stainless steel activation ball in open pipe. Advance RCJB to } 1520.5 \text { mbsf with slow } \\
\text { rotation and light WOB. Jog rotation attempting to catch debris. }\end{array}$ & & \\
\hline 335 & 22 May 2011 & 0700 & 1520.2 & $\mathrm{POOH}$ with the drill string and clear seafloor at $1015 \mathrm{~h}$; RCJB at rotary table at $1645 \mathrm{~h}$. & & \\
\hline 335 & 22 May 2011 & 0730 & 1520.2 & Rack T/D. & & \\
\hline 335 & 22 May 2011 & 0800 & 1520.2 & $\begin{array}{l}\mathrm{POOH} \text { with the drill string and clear seafloor at } 1015 \mathrm{~h} \text {. Rack back BHA. RCJB at rotary } \\
\text { table at } 1645 \mathrm{~h} \text {. Empty RCJB of congealed sepiolite and } 4 \text { large rocks (total weight }=8.9 \\
\mathrm{~kg} \text {; largest rock }=3.9 \mathrm{~kg} \text { ). Unload } 3 \text { EXJBs of cuttings and a few small metal fragments. }\end{array}$ & & \\
\hline 335 & 22 May 2011 & 1800 & 1520.2 & Rebuild and make up RCJB and 3 EXJBs with a 2-stand BHA and RIH to 1793 mbrf. & Reentry $58, \mathrm{RCJB}+3 \mathrm{EXJB}$ & 1.46 \\
\hline 335 & 23 May 2011 & 0000 & 1520.2 & Repair pneumatic supply lines for drawworks high clutch. & & \\
\hline 335 & 23 May 2011 & 0300 & 1520.2 & Resume RIH 1793 mbrf-1519.0 mbsf (TP at $1462.9 \mathrm{mbsf}$ ). & & \\
\hline 335 & 23 May 2011 & 1030 & 1520.2 & Hard tag at 1519.5 mbsf (tide adjusted). Work EXJBs. & & \\
\hline 335 & 23 May 2011 & 1045 & 1520.2 & Pump $100 \mathrm{bbl}$ sweep followed by seawater ( $2 \times$ volume). & & \\
\hline 335 & 23 May 2011 & 1230 & 1520.2 & $\begin{array}{l}\text { Drop ball and activate RCJB. Note increase in pressure of } 600 \text { psi. Unable to pass hard tag } \\
\text { at } 1519.0 \text { mbsf with maximum } W O B=7000 \mathrm{lb} \text { with very slow rotation. }\end{array}$ & & \\
\hline 335 & 23 May 2011 & 1315 & 1520.2 & $\begin{array}{l}\text { POOH. Clear seafloor at } 1725 \mathrm{~h} \text {. Slip and cut } 115 \mathrm{ft} \text { of drilling line. Resume POOH. RCJB at } \\
\text { the rotary table at } 0215 \mathrm{~h} \text {. RCJB contains } 3 \text { rocks (total weight }=5.0 \mathrm{~kg} \text { ). One rock }(1.4 \\
\mathrm{kg} \text { ) is gabbro. Angularity of the rocks indicates that they were freshly deposited with a } \\
\text { suspected origin somewhere in the bottom } 7 \mathrm{~m} \text { of the hole. EXJBs contain gravel sized } \\
\text { cuttings to small pebbles. }\end{array}$ & & \\
\hline 335 & 24 May 2011 & 0500 & 1520.2 & $\begin{array}{l}\text { Make up RCJB and } 3 \text { EXJBs with 2-stand BHA and RIH to } 1434.4 \text { mbsf (Reentry 21), and } \\
\text { then with T/D and minimum pump/rotation. Tag soft fill at } 1518.8 \text { mbsf. }\end{array}$ & Reentry 59, RCJB + 3 EXJB & 1.14 \\
\hline 335 & 24 May 2011 & 1615 & 1520.2 & Wash down to 1519.8 mbsf and work junk baskets. & & \\
\hline 335 & 24 May 2011 & 1630 & 1520.2 & Pump $100 \mathrm{bbl}$ of sepiolite sweep mud and chase with seawater $(2 \times$ volume). & & \\
\hline 335 & 24 May 2011 & 1800 & 1520.2 & Drop ball, activate RCJB, and work same. & & \\
\hline 335 & 24 May 2011 & 1845 & 1520.2 & Displace lower portion of annulus with $200 \mathrm{bbl}$ of drill water in preparation for logging. & & \\
\hline 335 & 24 May 2011 & 1930 & 1520.2 & $\begin{array}{l}\text { POOH. Clear seafloor at } 0100 \mathrm{~h} \text { and rotary table at } 0700 \mathrm{~h} \text {. Disassemble and empty RCJB } \\
\text { of } 4 \text { small cobbles. Empty } 3 \mathrm{EXJBs} \text { and clean out the usual assortment of cuttings, etc. }\end{array}$ & & \\
\hline 335 & 25 May 2011 & 0815 & 1520.2 & $\begin{array}{l}\text { Make up Bowen fishing magnet and } 3 \mathrm{EXJBs} \text { and RIH to } 1462.6 \mathrm{mbsf} \text {, and then with T/D } \\
\text { to } 1519 \text { (tag fill). Wash down to } 1520.0 \mathrm{mbsf} \text {. Work fishing magnet and junk baskets. }\end{array}$ & Reentry 60 , Bowen fishing magnet $+3 \mathrm{EXJB}$ & 1.03 \\
\hline 335 & 25 May 2011 & 2230 & 1520.2 & Displace lower annulus with $200 \mathrm{bbl}$ of drill water (preparing hole for logging). & & \\
\hline 335 & 25 May 2011 & 2300 & 1520.2 & $\begin{array}{l}\text { POOH. Clear seafloor at } 0230 \mathrm{~h} \text { and rotary table at } 0900 \mathrm{~h} \text {. Disassemble and empty EXJBs. } \\
\text { Fishing magnet contained very little metal debris, all of which was finely ground!??! }\end{array}$ & & \\
\hline 335 & 26 May 2011 & 0900 & 1520.2 & $\begin{array}{l}\text { Make up and deploy logging bit and collars; RIH to } 203.3 \text { mbsf. Pick up } 2 \text { knobbies and } \\
\text { set end of pipe at } 218.9 \text { mbsf. Rig up for logging. }\end{array}$ & $\begin{array}{l}\text { Reentry 61, downhole measurements (triple combo, FMS, } \\
\text { UBI) }\end{array}$ & 1.08 \\
\hline 335 & 26 May 2011 & 2030 & 1520.2 & $\begin{array}{l}\text { Make up Log } 1 \text { (triple combo-GR/APS/HLDS/HRLA/GPIT). Deploy Log } 1 \text { into the pipe at } \\
2255 \mathrm{~h} \text {. Reached the bottom of the hole at } 1520.0 \mathrm{mbsf} \text {. Recover tool at } 0700 \mathrm{~h} \text {. }\end{array}$ & & \\
\hline 335 & 26 May 2011 & 2300 & 1520.2 & Deploy Log 1 into pipe at $2255 \mathrm{~h}$. & & \\
\hline 335 & 27 May 2011 & 0700 & 1520.2 & Disassemble triple combo. Make up Log 2 (FMS-sonic); deploy into pipe at $1050 \mathrm{~h}$. & & \\
\hline 335 & 27 May 2011 & 1100 & 1520.2 & $\begin{array}{l}\text { Tool unable to exit pipe into hole. Recover FMS-sonic at } 1410 \mathrm{~h} \text {. Replace damaged lower } \\
\text { centralizer spring and redeploy FMS-sonic at } 1500 \mathrm{~h} \text {. Tool appears to jam inside BHA } \\
\text { with lower section }(\sim 20 \mathrm{~m}) \text { of unit extending } 20 \mathrm{~m} \text { into the open hole. Attempt to } \\
\text { pump tool clear without success. }\end{array}$ & FMS stuck in logging bit; end of logging & 1.13 \\
\hline 335 & 27 May 2011 & 1815 & 1520.2 & $\begin{array}{l}\text { Make up Kinley cutter assemblies. Drop crimper in pipe at } 2135 \mathrm{~h} \text {. Assemble Kinley } \\
\text { severing tool and drop into pipe at } 2315 \mathrm{~h} \text {; drop hammer and logging cable at } 0115 \mathrm{~h} \text {. }\end{array}$ & & \\
\hline 335 & 28 May 2011 & 0330 & 1520.2 & Recover and tie back logging cable. $\mathrm{POOH}$. Clear seafloor at $0425 \mathrm{~h}$. & & \\
\hline 335 & 28 May 2011 & 1200 & 1520.2 & Release jammed FMS-sonic tool from landing saver sub in BHA. Tool is in good condition. & & \\
\hline
\end{tabular}


Table T4 (continued).

\begin{tabular}{|c|c|c|c|c|c|c|}
\hline Leg & Date & Time & $\begin{array}{l}\text { Depth } \\
\text { (mbsf) }\end{array}$ & Comment & Brief run description & $\begin{array}{l}\text { Time } \\
\text { (days) }\end{array}$ \\
\hline 335 & 28 May 2011 & 1400 & 1520.2 & $\begin{array}{l}\text { Make up RCB 3-stand BHA with new RCB C9 bit. Check core barrel space-out and RIH to } \\
1430.5 \text { mbsf. Recover VIT and coat line on the way out. RIH with T/D to } 1520.2 \mathrm{mbsf} \text {. } \\
\text { Circulate } 100 \text { bbl sweep at } 1520.0 \text { mbsf. }\end{array}$ & $\begin{array}{l}\text { Reentry } 62 \text { ( } 24 \text { and last of Expedition } 335) \text {, coring (RCB C9 } \\
\text { bit), Core } 239 \mathrm{R} \text { ( } 36 \% \text { recovery; rollers) }\end{array}$ & 0.97 \\
\hline 335 & 29 May 2011 & 0515 & 1521.6 & $\begin{array}{l}\text { Drop fresh core barrel and rotary core } 1520.2-1521.6 \mathrm{mbsf} \text { (Core } 239 \mathrm{R} \text { ) at an average } \\
\mathrm{ROP}=0.6 \mathrm{~m} / \mathrm{h} \text {. Average recovery }=36 \% \text {. No indication of metal in the core barrel. No } \\
\text { symptoms of downhole junk in the coring process. Time for coring expires. Prepare for } \\
\text { cementing. Circulate } 50 \mathrm{bbl} \text { sweep at } 1521.6 \text { mbsf. }\end{array}$ & & \\
\hline 335 & 29 May 2011 & 1015 & 1521.6 & $\begin{array}{l}\text { RIH with the coring line to } 1510.6 \text { mbsf and coat same on retrieval. Rack sinker bars and } \\
\text { dress for layup period. Pull back in the hole with the T/D to } 1487.8 \text { mbsf. }\end{array}$ & & \\
\hline 335 & 29 May 2011 & 1315 & 1521.6 & Make up circulating head and pressure test. Position bit at 1518.6 mbsf. & Cementing $\mathrm{BOH}(10 \mathrm{~m})$ and $910-940 \mathrm{mbsf}$ interval to & 0.28 \\
\hline 335 & 29 May 2011 & 1345 & 1521.6 & Mix and pump $15 \mathrm{bbl}$ of $15 \mathrm{ppg}$ cement. Displace cement with seawater. & stabilize hole for Superfast 5 & \\
\hline 335 & 29 May 2011 & 1445 & 1521.6 & $\begin{array}{l}\text { Lay out circulating head and pull back in the hole to } 1372.6 \mathrm{mbsf} \text {. Flush drill string with } \\
\text { seawater }(2 \times \text { volume). Pull back with the drill string to } 940.8 \mathrm{mbsf} \text {. }\end{array}$ & & \\
\hline 335 & 29 May 2011 & 1715 & 1521.6 & Mix and pump $58 \mathrm{bbl}$ of 15 ppg cement slurry. Displace cement with seawater. & & \\
\hline 335 & 29 May 2011 & 1845 & 1521.6 & Pull back with the drill string to $739.3 \mathrm{mbsf}$. Flush drill string with seawater ( $2 \times$ volume). & & \\
\hline 335 & 29 May 2011 & 2000 & 1521.6 & $\mathrm{POOH}$ with the drill string to $3295.4 \mathrm{mbsf}$. Clear top of cone at $2135 \mathrm{~h}$. & $\mathrm{POOH}$; end of Expedition 335 & 0.05 \\
\hline 335 & 30 May 2011 & 0700 & 1521.6 & Recover beacons and secure vessel for sea. Under way to Panama. & End of Expedition 335 & \\
\hline 335 & & & & & Total: & 40.56 \\
\hline 1256D & & & & & Total: & 155.69 \\
\hline
\end{tabular}

Gray = beginning and end of legs, casing operations; blue = downhole measurements; green = coring; red = hardware failure and hole remediation/stabilization. $\mathrm{CADA}=$ cam-actuated drill-

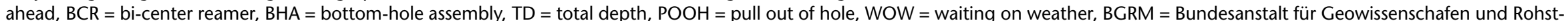

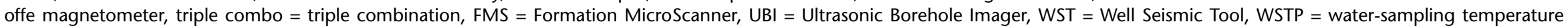

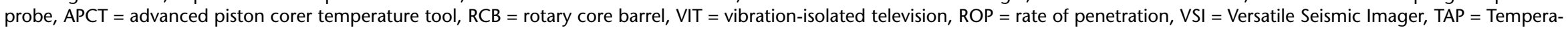
ture/Acceleration/Pressure tool, DLL $=$ Dual Laterolog, $\mathrm{SGT}=$ Scintillation Gamma Ray Tool, $\mathrm{RIH}=$ run in hole, $\mathrm{T} / \mathrm{D}=$ top drive, $\mathrm{WOB}=$ weight on bit, $\mathrm{SCR}=$ slow circulation rates, $\mathrm{TCl}=$ tungsten carbide inserts, $\mathrm{RC} J \mathrm{~B}=$ reverse circulation junk basket, $\mathrm{FT} \mid \mathrm{B}=$ flow-through junk basket, $\mathrm{EXJB}=$ external junk basket, $\mathrm{TP}=$ total penetration, $\mathrm{GR}=$ natural gamma ray logging tool, $\mathrm{APS}=$

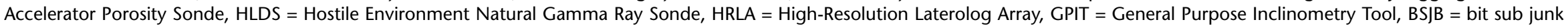
basket, $\mathrm{BOH}=$ bottom of hole. This table is available in ASCII and in Microsoft Excel format (see 104_T4.XLS in CHAPTER_104 in TABLES in "Supplementary material"). 